\title{
A HISTORY OF DISCOVERY, STUDY AND EXPLOITATION OF COAL IN TASMANIA
}

\author{
by Carol A. Bacøn and Maxwell R. Banks
}

(with four tables, ten text-figures and three appendices)

BACON, C.A. \& BANKS, M.R., 1989 (31:x): A history of discovery, study and exploitation of coal in Tasmania. Pap. Proc. R. Soc. Tasm. 123: 137-189. https://doi.org/10.26749/rstpp.123.137 ISSN 0080-4703. Department of Mincs, PO Box 56, Rosny Park, Tasmania 7018 and Department of Geology, University of Tasmania, GPO Box 252C, Hobart, Tasmania 7001, Australia.

The history of discovery of coal in Tasmania, the history of geological work on the coal and the history and methods of exploitation of the coal have been influenced by three main factors: (1) population spread and density, (2) geology, including quality, of coal and (3) economic conditions. The pattern of discovery showed the effects of population growth and the spread of settlement in the island and, particularly in the early days of the colony, the types of discoverers reflected important groups in the population. Study of the coal was, for the greater part of last century, carried out by visiting naturalists, amateurs (some of them gifted) or overseas experts. Even when this situation changed and the work was done by resident geologists, the study usually depended on concepts and practices developed elsewhere. The derivative nature of this work is a reflection of the generally poor quality of known coals and, by and large, low known coal reserves. The history of mining reflects the geology of the coal deposits, changes in the means and availability of transport and, in general, economic conditions. Coal mining had significant effects on only two Tasmanian communities. The discovery and quality of coal in the Don and Mersey Valleys attracted many people to the area in the 1850's and early 1860's but the prevalence of faults and thinness of seams precluded later significant developments. The opening of the railway to the eastern end of the South Esk valley in 1886 improved the ease and reduced the cost of transportation, and thus led to increased demand for production of coals from the Fingal-St Marys area. The opening initiated a long period during which coal mining made a significant impact on the economy of that area. The thick and relatively unfaulted seams there allowed economic mining until the low oil prices of the 1960's combined with the relatively low quality and total reserves of coal to force closures of mines, which severely disturbed the communities of Fingal and St Marys.

Key Words: Tasmania, coal, coal mining, coal discovery.

\section{INTRODUCTION}

Now that the intense activity in exploring for coal which affected Tasmania in the past decade has subsided, it seems an appropriate time for contemplation, for looking back at the discoveries of coal and those who made them, at the investigation of the coal, and at the history and effects of coal mining in the State. The recent period of intense exploratory activity was not the first; that occurred in a period, about a quarter of a century, beginning with the discovery of coal at Saltwater River in 1833. A second period of intense activity, near the turn of the century, followed the development of rail transport, when the emphasis was on the expansion of mining in the South Esk Valley.

As with the recent activity so also with this history - it is not the first. The Coal Resources Bulletin (Hills et al. 1922) dealt in passing with some historical aspects. A more systematic but also incomplete treatment was provided by Besford in
1958 to be followed by one (Booth 1962) with a very different emphasis from earlier ones and from this present one.

\section{GENERAL BACKGROUND}

Coal has been used as a fuel in Britain for almost two millenia and in southern Europe for rather more than that. Its importance as a source of heat and a reducing agent has guaranteed State and private interest in it for many centuries. Coal was dug on the shores of the Firth of Forth about AD 1200 (Cantrill 1914: 4 et seq.) and in Northumberland and Durham in the reign of Henry III (first half of thirteenth century). By the middle of the 14th century, coal was mined in pits and raised by windlasses. Boring to prove coal before mining began in northern England early in the 17th century. As early as 1719 Strachey demonstrated the stratigraphy and structure of a coalfield south of Bristol (Strachey 1719). In the year following 
the white settlement of Australia, a remarkably complete description of coal-bearing sequences in Great Brinin was published (Williams 1789 quoted in Zitrel 1901: 109). A treatise dated 1708 described methods of coal mining, which was then the "bordand-pillar" system (Cantrill 1914: 14). Longwall mining, as opposed to bord-and pillar, did not become common until the last decade of the 18 th century. In the 1730 's coke, derived from coal, was first used in the smelting of iron, the practice starting at Coalbrookdale in Shropshire (Cantrill 1914: 20). By the end of the 18th century, when exploration of Tasmania was intensifying, and a little later, after settlement began, coal was widely used in Britain not only as a source of heat but in smelting, as the source of the reducing agent.

It was thus well known by the time of the settlement of Tasmania that coal was economically important. Much was known of the geology of coal in Britain and western Europe, and the importance of the number and thickness of seams in a locality, the dip of the seams, the associated rocks, the presence of faulting and the quality (heat capacity, calorific value, specific energy) were well understood. It is no accident that the first discoverer of coal in Tasmania noted the thickness, dip and associated rocks.

Had there been thick seams of coal readily accessible to the new settlements on the Derwent and Tamar, less timber close at hand as a source of fuel or greater populations, the rate of discovery of coal might have been higher and the first serious attempt at mining might have occurred much earlier than it did, i.e. 30 years after settlement began.

In this paper, we want to look at who discovered coal in Tasmania, where and when. The discoveries were not random. We will explore the way in which geological information on the coal accumulated and changed. There is a suggestion that in too many cases the possible effects of geological conditions on the mining of coal have been ignored. Mining methods have been influenced by the geology of the coal measures and the topography of the State. The intensity of mining, governed by technological and economic factors outside the coal industry and, on some occasions, outside Tasmania, has been variable; the success rate has been low.

Apart from the sources included in the list of references, material has been drawn from records held in Tasmanian State Archives and some other records. A list of these will be found after the reference list.

\section{DISCOVERIES AND DISCOVERERS}

Even before David Collins reached the Derwent to found Hobart Town early in 1804, coal had been discovered twice in Tasmania. The first discovery was made by French naturalist Labillardière in February 1793 in the cliffs lining what is now called South Cape Bay. Labillardière reported

"... the side of the mountains being exposed for a considerable extent we observed a horizontal vein of coal the greatest thickness of which did not exceed one decimetre. We noticed it for a space of more than $300 \mathrm{~m}$. The stratum below it was sandstone and above it a dark shale. From these indications I presume that excellent coal may be found in abundance at greater depth. It is well known that the richest mines of this fuel are commonly found below sandstone ..." (translated from Labillardière 1800, Vol. 2: 22).

Labillardière was the naturalist with the D'Entrecasteaux Expedition returning from the unsuccessful expedition into the Pacific in a search for La Pérouse. He had studied botany at Montpelier and had a medical degree from Paris (Australian Dictionary of Biography $(A D B)$ Vol. 2, 1967: 69). It is likely that the studies for his degree included some readings in natural philosophy, including geology.

On 8 November 1803, James Meehan discovered coal in a "high rocky bank" beside the Coal River just downstream from what is now Richmond and marked his map "coal here". James Meehan had been sent on an exploratory expedition from Risdon Cove by Lieut. John Bowen, the Commandant of this first European settlement on the Derwent River. Earlier, Meehan, transported at age 24 for his part in the Irish Rebellion of 1798 and assigned as servant to Charles Grimes, Acting Surveyor General of New South Wales, had accompanied Lieut. Robbins as a "kind of mineralogist" (HRNSW V: 136) during a survey of King Island late in 1802 .

Captain James Kelly discovered brown coal on the northern shore of Macquarie Harbour in 1815 and his report was promptly followed up by a visit by $\mathrm{Mr}$ Denis McCarty who reported

"... a quantity of coal ... an immense bed ... the bank from the river was nearly all coal in strata $6 \mathrm{ft}[1.8 \mathrm{~m}]$ thick then a few feet strata of clay then coal again ..." (Hobart Town Gazette 15 June 1816).

Captain Kelly later (1820) reported the existence of three seams of coal at Macquarie Harbour (HRA III 
(3): 466). James Kelly was born in Parramatta, NSW, in 1791 , made several voyages before he was 13 and had become a master mariner by 1812 . He was later well-known as an entrepreneur in Hobart (Pretyman 1967).

Later discoveries (or first reports of discoveries) and discoverers are tabulated as appendix 1.

Of the discoverers, Joseph Milligan and Charles Gould play significant roles in understanding the geology of Tasmanian coal, and their contribution will be dealt with at greater length in the next section. The other discoverers seem to have had a variety of professions and occupations. Only surveyors seem to be better represented than others. The role of James Meehan has already been noted. Other surveyors were George Woodward and James Hughes who discovered coal at Saltwater River; like Meehan, they were former convicts. Woodward acted as a surveyor in Hobart from 1826 to 1831 and was then convicted on a forgery charge. Hughes was transported for seven years for obtaining 15 plants by false pretences (Heard 1981:248). From 6 March 1833 to December 1833 he was employed at a shilling a day to make a survey of the Tasman and Forestier Peninsulas, a task completed on 24 August 1833. Other convicts who discovered coal were Jesse and Isaac Garland and Zephaniah Williams, of whom more later. Burgess, also a contract surveyor, who found coal in 1852 at Coal Hill, was one of the early explorers in western Tasmania. That surveyors were prominent as a group among the discoverers of coal comes as no surprise, since their training included studies on natural productions including minerals and rocks, and the practice of their profession commonly involved work in sparsely populated and poorly explored areas.

Of the discoveries prior to 1840 , many were in coastal situations and some of the rest in cliff sections by streams. Subsequent discoveries were predominantly inland but even then many were in river or creek sections. The locales of the discoveries, i.e. mainly in marine or river cliffs or in stream beds, are readily explicable as only in such situations do coal seams normally crop out noticeably.

When the sites of discoveries and first reports are plotted on maps for successive time periods, relationships emerge between the distribution of sites on the one hand and early maritime exploration or the spread of settlement on the other. Thus, discoveries prior to and including 1820 (fig. 1A) were in coastal or estuarine cliffs, plus one in a river bank section seen on the first inland exploration and one doubtfully of this period in the bank of a branch of the Coal River above Colebrook some kilometres beyond settement in that valley. The few known discoveries in the decade to 1830 were close to Hobart Town and on the Huon River (fig. 1B). Subsequent discoveries were made in several coastal sections, up the Derwent Valley well within the limit of settlement at the time (cf. Plomiey 1971: map 2 as amended) and within the Van Diemen's Land Company (VOL Co.) area (fig. 1C). The map for the $1841-50$ decade (fig. 1D) shows distinct correlation with Plomley's map as amended (1971) and the extent of land alienation in 1854 (Scott 1965: map 8). On the other hand, coal discovery localities and timing are, after an initial period, poorily related to the process of exploration (cf. maps herein, with Maude 1965: figs 32-33). Discoveries in the next decade show a concentration in the newly inhabited Mersey and Don areas, with an isolated discovery arising during the early stages of probing into western Tasmania (fig. 1E). As settlement spread in the Huon district, coal discoveries followed (figs. $1 F$ to 1 I and Scott 1965: map 8). Discovery of tin at Mt Bischoff in 1871 led initially to discoveries of lignite nearby (fig. 1G) and then to discoveries of black coal and lignite further away in the Central Highlands and in western Tasmania (figs. 1H to 1I), e.g. south of Zeehan. Thus, from 1793 to about 1910 the discovery of coal was connected with maritime (initially) and inland (later) exploration and with the spread of settlement. Blainey (1961: 344-345) noted the importance of accessibility in the pattern of spread of gold discoveries. This factor was also important in the distribution of coal discoveries in Tasmania.

The pattern of discoveries through time is not random (fig. $2 \mathrm{~A}$ (ii), $\mathrm{B}$ (ii)). The rate of discovery was slow and increased slowly until 1833 (the discovery at Saltwater River). Thereafter the rate increased to such an extent that the Cornwall Chronicle of 2 April 1851 was able to comment, in reporting the discovery of coal on the Don River a few weeks before, that "the discovery of coal lately in this island has become a sort of mania". Subsequently the rate slowed down but reached a second but lower peak in the 1881-90 decade, followed by a further deceleration, with a third peak, lower again, between 1921 and 1930, and finally a further, even lower peak in the 1951 to 1960 decade. It is interesting to note the parallelism in the rise of population of the island (fig. 2A(i)) and the increase in number of coal discoveries (fig. $2 \mathrm{~A}$ (ii)), also fig. $2 \mathrm{~B}$ (i) and (ii). These two parameters varied sympathetically until 1930 , after which the rate of coal discovery dropped 

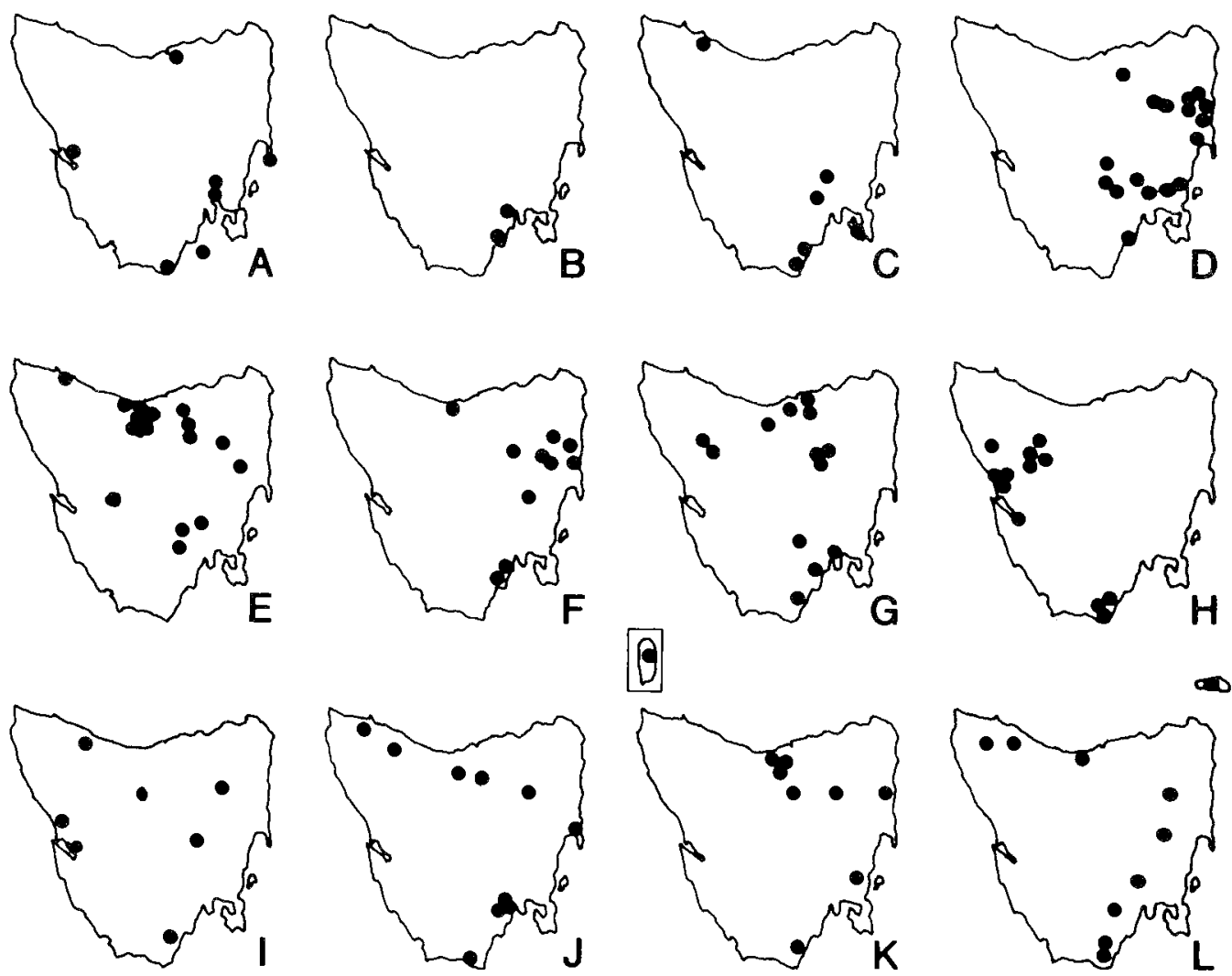

FIG. I-Geographical distribution of coal discoveries in Tasmania in successive periods:

(A) pre-1820, (B) 1821-30, (C) 1831-40, (D) 1841-50, (E) 1851-60, (F) 1861-80, (G) 1881-90, (H) 1891-1900, (I) 1901-10, (J) 1911-20, (K) 1921-30, (L) post-1930.

FIG. 2 (opposite) (A)(i) increase in population of Tasmania (mainly after Tasmanian Year Book 1975: 158); (ii) total number of discoveries of coal made or reported in Tasmania in successive decades, e.g. I811-20,1821-30 ...; (iii) progressive total of mine openings at end of successive decades (from Department of Mines production records).

$(B)(i)$ curve showing rate of increase of population of Tasmania, decade by decade (points on curve calculated by dividing population at end of one decade (say 1930) by population at end of previous decade (say 1920) (from Tasmanian Year Book 1975: 158); (ii) number of discoveries of coal in successive decades (based on appendix 1); (iii) number of openings of coal mines in successive decades (number of re-openings in each decade noted); based on details in appendix 2.

(C) number of mines producing each year. 


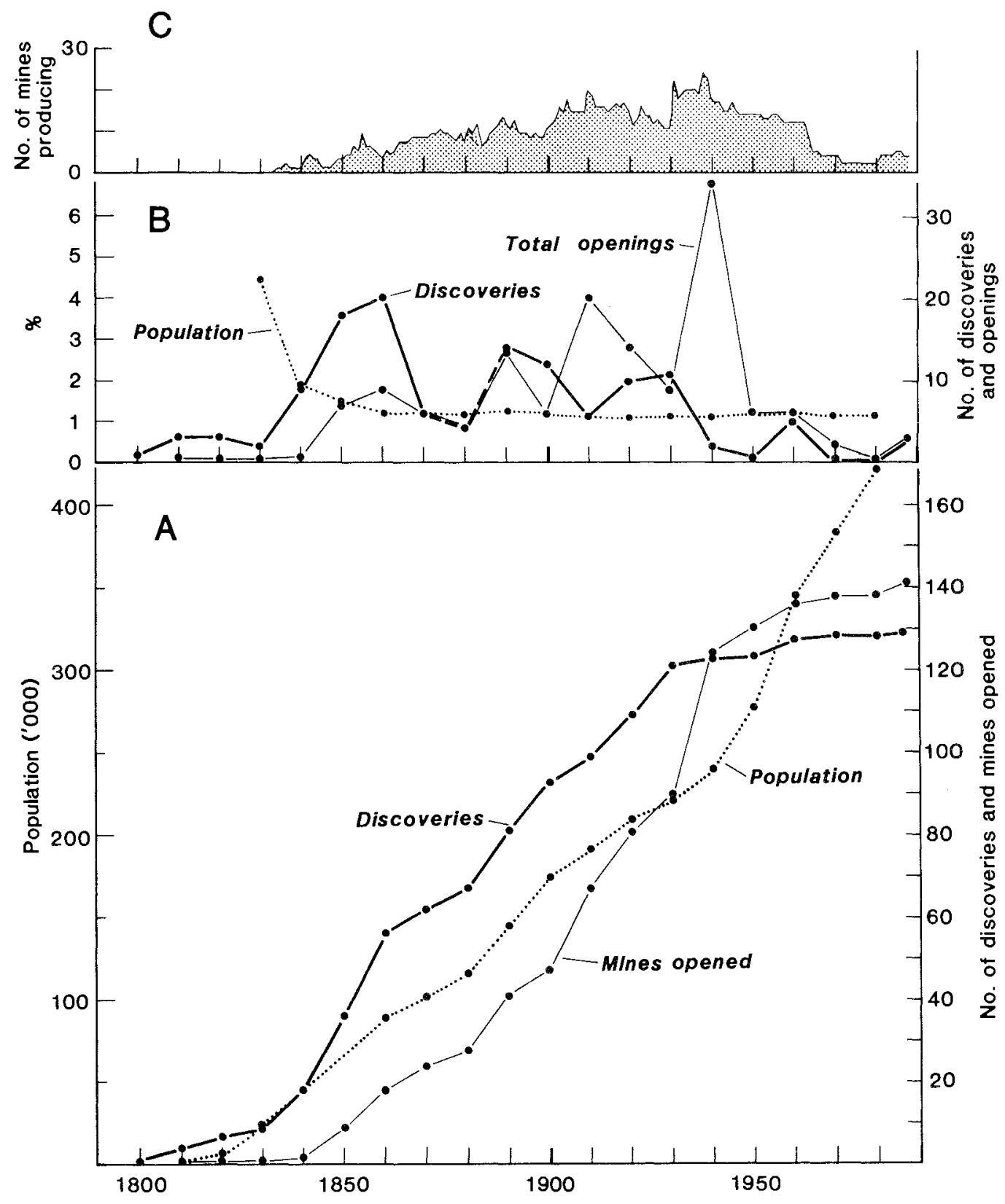


drastically. The slowing in the rate of discovery is probably a reflection of the fact that most of the onshore areas likely to contain coal had been explored by that time (the graph — fig. 2A(ii) takes no cognisance of coals discovered at depth offshore in the last couple of decades).

Some of the causes of at least the first two peaks in discolery rate can be inferred with some confidence. The build-up probably began with the appointment of Lieut.-Governor Arthur, during whose term of office exploratory work by Hobbs and others, visits by Scott and the report of 1826 of the Land Commissioners resulted in marked increase in knowledge of mineral distribution, including coal. The next step was the appointment of George Frankland as Surveyor General, commissioned by Hay on behalf of Earl Bathurst to collect "information in regard to Geology and Natural History" (HRA III(5): 234). Surveyors Woodward and Hughes, under instructions from Frankland to survey Tasman Peninsula, found coal at Saltwater River early in 1833. The subsequent mining of this coal alerted the public to the importance of this mineral. Sir John Franklin, the Lieut.-Governor who followed Arthur, fostered knowledge of science, including geology, and entertained and encouraged visiting naturalists like Strzelecki, Jukes, Sir John Ross and others. Strzelecki is perhaps noteworthy in this respect as he visited many parts of Van Diemens Land, examined coal seams and analysed some of the coal. These activities probably drew the attention of people in many parts of the State to the occurrence of coal. The possibility of using coal mining as a useful occupation for convicts was certainly favourably entertained by Lieut.Governor Sorell and then by Arthur and later Lieut.-Governors, and several abortive attempts were made to develop this possibility (e.g. Jerusalem and Schouten lsland). The possibility of commercial exploitation of coal also emerged publicly in 1840 with an attempt to mine coal at Southport (see later) and was followed by others. The discovery of copper ore in South Australia led to the need for coal (or coke) for smelting, and a company was formed in Tasmania in 1848 to supply this need.

Impetus was added to the already accelerating rate of discovery when Lieut-Governor Sir William Denison was asked by the Lords of the Admiralty in 1847 to obtain a report on coal in Tasmania so that coal supplies for bunkering the increasing number of steam-driven vessels in the British Navy could be ensured (TSA Outward Despatches 67; 18 May 1849). He commissioned
Joseph Milligan on 14 January 1848 to examine the coalfields (TSA 24/261/5844, CSO 24/40/1257), and detailed the sort of information he required on 31 January of that year. Denison asked Milligan to concentrate on coal basins near the coast, to report on quality, locality, especially with respect to ease and distance of transport, and the presence of faults and "dikes", on the topography as it influenced mining, on the thickness, dip and associated rocks and on the means of removing water from any mine.

The first report, that on Schouten Island, was completed by 15 August of that year (Proc. R. Soc. $V D L$ 1: 1). The second report was commissioned on 28 August 1848 (Milligan 1849: 31); this was to be on Fingal and $\mathrm{Mt}$ Nicholas (completed 8 November 1848) and on Richmond and Jerusalem (now Colebrook) (completed on 13 February 1849, Pap. Proc. R. Soc. VDL 1: 67). After coal was discovered in the Mersey area, Milligan was commissioned to report on that field (31 March 1851: TSA 24/261/5844).

The discovery of coal on the Don River early in 1851 was followed by intense exploration activity there involving a number of individuals and groups. Many discoveries followed in the area within the decade. During his exploratory activity Lieut.Governor Fox Young commissioned A.R.C. Selwyn of the Geological Survey of Victoria to report on the coalfields. His activities, and controversy arising therefrom, were reported in the Tasmanian press, thus indicating and probably increasing public interest. The growth in the discovery rate leading to this first peak suggests a multiplier effect, in that one or a few events produced interest which led to more discoveries which triggered further interest...

Why did the rate not continue to rise after 1860 ? For one thing, the population increase slowed; for another, Tasmania entered a period of economic stagnation (McGhee 1969: 138). Mersey coal was not proving as profitable as expected. Mines had already opened and closed in the 1850 's, due to thin seams and the frequency of faults. The Select Committee on coal which reported in 1864 had heard evidence that the coal was suitable only for steam-raising, and competition from the better coal sold by the much more developed NSW coal industry ensured that production of Tasmanian coal was mainly, if not solely, for use within the State, i.e. it had a relatively small market.

The population began to rise again in the decade beginning 1881 and railways had been opened (Launceston to Deloraine 1871, Hobart to Launceston 1876). During this decade (1886) the 
line from Conara Junction to St Marys was opened. The railways not only provided a steady new market for the coal but also access to the coallields. The discovery of tin at Mt Bischoff in 1871 brought population to new areas, increasing the chance of discovery of metals and coal. From Bischoff, in fact or in effect, waves of prospectors spread into previously remote or inaccessible parts of westem Tasmania and the Central Highlands and discovered metalliferous deposits. Prospectors and timber cutters working out from the new metalli. ferous mineral discoveries also discovered coal. The later part of the last century was also the time of development in the Huon district (Scott 1965: map 8, Centenary of Settlement of the Huon. Huon Newsletter Newspaper Co., Franklin 1936) orcharding in the valleys near the Huon River and timber-seeking and then logging in the higher country and further away. The timber-seeking and logging activities provided access to new areas and coal discoveries followed. The second peak in discovery rate thus seems to have been influenced by population rise, opening of railways, discovery of metalliferous mineral deposits and the development of the timber industry. To some extent the second peak also reflects the activities of one man, Robert Mackenzie Johnston, in collating information on coal and publishing some discoveries, mainly of lignite, for the first time (Johnston 1873, 1888).

The discovery rate fell off again in the first two decades of the 20th century. Another depression had started in the 1880 's and deepened in the 1890's (L'Huillier 1969: 186), and its effects lasted into the first years of this century. Subsequently the First World War diverted attention and manpower away from relatively minor activities like coal search. Late in the War and in immediately postwar years, governmental interest in possible sources of power for industry led to systematic geological survey (Hills et al. 1922: 268-269); this resulted in the recording of some discoveries but, in addition, probably triggered interest from prospectors or entrepreneurial groups, from which a few discoveries also flowed. After 1930, the rate of discovery fell drastically as the economic depression of the late twenties and thirties took hold and it was not until the post-World War II decade of the 1950's that higher population growth, some of it by immigration, and booming economic conditions again provided support and incentive for coal search from which some discoveries followed.

The great activity in coal search in the 1970's, triggered by marked increase in the price of oil, was mainly directed to further exploration or dovelopment of known fields wher than search for new ones. Nevertheless a new field, at Woodbury, was discovered and another, previously neglected, at Rosevale was "rediscovered". Subsequent finds secm to be minor and have occurted during geological work by the Depammert of Mines.

It is interesing to note that discovery of black coal has always excited much more interest than that of lignite in Tasmantas. The morence in interest is probably a function of the greater value of black coal and the greater thickess of seams in the black coal.

\section{NCREASING KNOWLEDGE OF THE GEOLOGY OF TASMANIAN COAL}

As a background to the history of geological study of coal to be outlined in this section, a summary of present knowledge may be useful. The oldest Tasmanian coals are Early Permian in age and lie between sequences of marine rocks. Above the higher of these marine sequences are Upper Permian coal measures, separated in turn by a fluviatile succession from the main coal measures of Late Triassic age. The Permian and Triassic coals are black and occur as almost horizontal to gently dipping beds commonly disrupted by faulting or by intrusions of Jurassic dolerite, in the form of sills, sheets or dykes.

Because of the disruption, individual coalbearing blocks may be only a few hundred metres in maximum horizontal dimension. Prediction of seams across faults and through dolerite intrusions is extremely difficult. Brown coals and lignites of Early to Mid-Tertiary age occur as horizontal beds in a number of places.

The early discoverers of coal in Van Diemens Land were careful to note the thickness and number of seams, the economic aspects. Thus even the earliest record of coal in Tasmania, that of Labillardière (1800), included comments on the thickness of the seam and on the associated sedimentary rocks, and noted that they were horizontal. McCarty (Hobart Town Gazette 15 June 1816) and Kelly (HRA III(3): 466) commented on the thickness and number of seams at Macquarie Harbour. In J.T. Bigge's Commission of Enquiry (HRA III(3): 257) it was noted that the seam at Adventure Bay was two feet $(0.6 \mathrm{~m})$ thick and dipped a little to the southwest.

Archdeacon Thomas Scott (1824) regarded rocks at Hobart and George Town as being of the "the coal formation", i.e. like the Permo-Triassic rocks near Sydney and Newcastle which he referred to as 
"the c oal measures", inferring thereby a Carboniferous age for them by lithological correlation with Great Britain. Winch (1823) noted the presence of fossil leaves above and below the coal at "Hobart's Town'" and also assigned a Carboniferous age to the coal.

Early in 1824 John Busby (or Bushby) reported on coal and water near Hobart (Hobart Town Gazette 20 February 1824). He noted three seams at Richmond and gave strike and dip $\left(30^{\circ}\right.$ to the SSE). The lowest seam ( $1.2 \mathrm{~m}$ thick), he noted, lay between sandstone beds and contained thin strata of clay. He noticed the proximity of "whin" (dolerite) dykes to which he attributed the dip of the seam and the low "combustibility" of the coal. He also recorded that the coal was brittle. A coal specimen from Schouten Island he likened to splint coal, which, because of its "tenacity", he thought was likely to carry well. He disputed the correctness of a report (untraced) by one Jackson on the Macquarie Harbour coal. In a report to Lieut.-Governor Arthur (CSO 1/67/1351) Hobbs raised the possibility of a vein of coal running (with dislocations) from Hobart to South Cape Bay.

The report by Winch (1823) on coal at New Town probably had little effect in Hobart Town as it was published in a British scientific journal. More local attention was attracted by reports in the Hobart Town Gazette (12 May 1827) of coal dug up in a well on Mr Emmett's farm on New Town Road, and there was a further report in 1829.

In travelling through Lenah Valley to the upper reaches of Tolosa Street, Glenorchy, in February 1836, Charles Darwin saw coal, again in close association with dolerite (Banks 1971).

Sir John Franklin commissioned a visiting Polish explorer, Dr John Lhotsky, late in 1836 to report on the coal and coal mining at Saltwater River. Lhotsky was to be paid ten shillings a day. His arrival on 17 February 1837 was noted by the Commandant, O'Hara Booth (Heard 1981: 207). His report (CSO 5/72/1584) included a geological section of a shaft $24 \mathrm{~m}$ deep in sandstone and shale with plant impressions. He provided both a neat, detailed map of the coal-mining area itself, showing the coal trending west-northwest between sandstone beds, and a map of the Forestier and Tasman Peninsulas showing, in colour, small areas of "trap" (= dolerite), greywacke (Permian Fern Tree Mudstone), sandstone (Triassic), and coal measures (also Triassic), some of them in contact. This is the earliest attempt at a geological map of any part of the State. He made some very sensible suggestions for working the mine, including keeping records of strata cut in boring or shaft sinking. Lhotsky used a theory of coal formation current at the time - chemical softening of ligneous matter followed by heating under various pressures (Macculloch 1831). He used a theory that much coal was deposited at the foot of and along the flanks of "primitive" mountains (i.e. mountains of igneous or metamorphic rocks) to suggest deeper drilling and seeking better coal elsewhere.

Faulting was recognised - as "throws" in the Saltwater River mine as early as 1834 (O'Hara Booth's journal, Heard 1981: 179). A report to the Executive Council dated 1 September 1841 (LSD 1/28/458-464) provided not only a description of the stratigraphic succession involving the coal at Jerusalcm but also a geological sketch section from Jerusalem to Richmond, showing southerly dipping beds dislocated by normal faults downthrowing to the north. No author is quoted for this report but it could well have been the Polish explorer, Strzelecki, who was in Tasmania at the time (compare this report with Strzelecki 1845: 127). P.E. von Strzelecki recognised two coal "basins" in Tasmania, the South Esk Basin in the Avoca to St Marys area and the Jerusalem Basin in southeastern Tasmania. The coals in these basins he placed in the "Third Epoch", as he did also those in the Newcastle Basin of NSW (1845: 123) but commented cryptically (but correctly as it proved) that the "deposits... seem to differ in point of date". As it is, he included the Late Permian Southport coal with the Late Triassic coal from other areas. He even suggested (ibid.: 129) the possibility that the Jerusalem coals might be older than those from the South Esk (same age) and Newcastle Basins (actually older than Jerusalem coals). He described and provided both proximate and ultimate analyses of coals (see also Strzelecki 1842), as well as analyses of gases derived by burning of coal from Port Arthur (Saltwater River), Richmond, Recherche Bay, Colebrook and Jericho, and of lignitic wood and earthy lignite (from Nine Mile Marsh). He generally named the coals using the system of Jameson (1808), with names according to Brongniart (1807) as subtitles. His ultimate analyses must be suspect as he recorded nitrogen contents usually about $10 \%$ but up to $16 \%$. Later analyses for nitrogen (Hills et al. 1922: 28-30) are of the order of $1 \%$. The method of analysis of nitrogen is not stated. The $\mathrm{H}_{2} \mathrm{~S}$ content of the gas resulting from burning the coal also seems too high, up to $18 \%$. On the positive side, it should be noted that Strzelecki was the first to publish a statement on the faulting of the coal, observed the coking effect of dolerite intrusions at Recherche Bay and Southport (ibid.: 141) and first correlated 
coal seams (one at Jericho with the upper seam at Jerusalem (ibid: 139)).

While in Australia, Strzelecki collected fossil plants which he gave to J. Morris in England for description. Under the heading "Carboniferous Flora" (Strzelecki 1845: 245) Morris described (a) Glossopteris browniana from Newcastle, likening it to G. phillipsii (now Sagenopteris) from the Oolitic (Jurassic) of England; (b) Pecopteris (now Cladophlebis) australis from the Jerusalem Basin, likening it to two species from the Oolitic Series and noting its analogy to $P$. lindleyana of the Burdwan Coalfield of India, then regarded as Oolitic in age; (c) $P$. (now Dicroidium) odontopteroides, likened to a Permian fern Odontopteris permiana from Russia, which he recorded from the Jerusalem Basin; and (d) Zeugophyllites (now Phoenicopsis) elongatus from the Jerusalem Basin. Morris remarked (ibid.: 251) that neither in the Hunter nor in the Jerusalem Basin did any of the characteristic plants of the Carboniferous coal measures of Europe occur, and seems to have been uncertain of the contemporaneity of the Hunter and Jerusalem basins ("if indeed contemporaneous": 252). He attributed the differences in fossil content to geographical variation. He then went on (ibid.: 253) to note the similarities of the Hunter and Jerusalem Basin floras taken together with that of the Burdwan Coalfield of India and the Oolitic of England. In making such comparisons he was deceived, as was M'Coy a little later (1847), by homeomorphy (similarity in form) of leaf form and venation in the fossil plants. M'Coy $(1847,1848)$ compounded the confusion by insisting that the coal measures at Newcastle in the Hunter Basin were the same age as the coals of the Jerusalem Basin because of the presence in both of Pecopteris odontopteroides and Zeugophyllites (a misidentification in the Newcastle sequence of Noeggerathiopsis = Cordaites). He also insisted that both were Jurassic (Oolitic) by correlation with Burdwan (actually Permian) and the Oolitic of northern England. Thus began the notorious controversy between M'Coy and W.B. Clarke on the age of the Australian coal measures (see Vallance 1981 and Murray 1983), Clarke maintaining a Carboniferous age.

A major advance in knowledge of coal came with the commissioning of Joseph Milligan by Sir William Denison to report on Tasmanian coals. Joseph Milligan had come to Tasmania in 1831 with a diploma in medicine from the University of Edinburgh to be a surgeon with the VDL Co. (Hoddinott 1967: 230-231). Attention has already been drawn to his record of coal from near
Hampshire in 1832 and his commissions from Denison to report on the coal basins. By 1852 his reports on coal at Schouten Island, South Cape, Whale Head, Fingal, Mt Nicholas, Richmond, Jerusalem and the Mersey had been published. He described the coal-bearing beds and especially the coal, very clearly and provided accurately measured stratigraphic sections as well as accurate, realistic cross-sections, the first in Tasmania. He correctly inferred the sill-like nature of the dolerite body on Mt Nicholas and that the dolerite on Ben Lomond was younger than the coal (Pap. Proc. $R$. Soc, VDL II(I): 166), contrary to the views of Strzelecki. In Milligan's view the coals at all the places noted were the same age and Carboniferous. Milligan recognised three types of coal - cannel, bituminous and anthracite. For each coalfield studied, Milligan commented on the quality and quantity of coal available and in several places estimated reserves. He noted the distribution and structure of the coal areas, described or recommended mining methods and made a careful study of the access for coal to means of transport and the Tasmanian market, thus satisfying the terms of Denison's commission. He recommended the development of some fields, further exploration of others and neglect of the South Cape-Whales Head field. He was not enthusiastic about the prospects of coal on the Don River.

Probably arising from this survey Denison sent specimens to de la Beche, Director of the Geological Survey of Great Britain, for analysis. De la Beche (1851) was not impressed, largely because of the ash content but partly also because of the sulphur content - "the coals cannot be considered as at all first class coals".

Less than ten years later, Governor Sir Henry Fox Young commissioned the Chief Geologist of the Geological Survey of Victoria, A.R.C. Selwyn, to report on the coalfields. Selwyn visited Tasmania in April and May 1855 (Dunn 1910: 9) and reported, adding comments on new fields near Plenty and near Triabunna as well as bringing up to date information on the rapidly developing Mersey field. Selwyn was misled by the apparent lack of metamorphism of contiguous sedimentary rocks by the dolerite into considering that some of the dolerite was older than the "carboniferous" sediments, e.g. in the Douglas River area (1855: 126). As a result he postulated incorrectly that coal would not pass beneath the dolerite near the present Duncan Mine, southeast of Fingal. He was also misled by the known sections in the South Esk Valley, in the Sydney Basin and in Britain, where coal overlies fossiliferous marine beds including 
limestones, to suggest that, in the Mersey Basin, once marine fossils were encountered in drilling, further drilling would not reveal coal. He was right for the particular shaft he was discussing but wrong to try to apply the principle generally in the Mersey field, as pointed out by Zephaniah Williams, a local mine manager (see Burns 1964: 89, 95, 222 et seq. for details). He assumed that known coals in Tasmania were all of one age.

The advent of the first Geological Surveyor of Tasmania, Charles Gould, in 1859 brought for the first time a trained geologist into a full-time professional position in Tasmania. Gould, a son of the famous omithologist John Gould, graduated from the University of London, where his teachers had included the well-known field geologist Andrew Ramsay and the famous biologist and palaeontologist Thomas Huxley. He had subsequently worked in the Geological Survey of Great Britain under Sir Roderick Murchison. As early as August 1859, he was working on coal at Fingal, and over the next ten years he visited and reported on most of the coalfields including the Mersey field. By mid 1861 , Gould had recognised that the coal in the Mersey field was not the same age as that in the Fingal Valley (letter to Murchison) and he published that view later in the year (Gould 1861b), thus breaking one of the links in M'Coy's argument that the Newcastle and Jerusalem coals were equivalent and Oolitic in age, and anticipating by eleven years Daintree's (1872) conclusion that both Palaeozoic and Mesozoic coals were present in eastern Australia (Murray 1983: 8). In that same report Gould also showed that coal occurs below rocks with Upper Palaeozoic marine fossils, thus proving Selwyn wrong. Further, in another report in 1861 ( $H A J$ pap. 9) on the Mt Nicholas Field he provided good stratigraphic sections of the succession on St Pauls Dome and in Piccaninny Creek, and showed in a geological cross-section the coal passing beneath the younger dolerite cap on Mt Nicholas. In that same year, 1861, he also suggested (HAJ pap. 65) the establishment of a Coal Commission, which was subsequently set up with Gould as one of its members. A few years later (1865: 63-66) he summarised his views on two ages of coal in Tasmania and on the age of the dolerite.

By 1888 , the general sequence of the coalbearing beds in the Sydney Basin, i.e. Lower Marine Beds, Lower Coal Measures, Upper Marine Beds, Upper Coal Measures, had been recognised (Clarke 1878:66) and some of the plant fossils characteristic of each of the two coal measures were known. In addenda to A Systematic Account of the Geology of Tasmania, R.M. Johnston (1888: 202-207) arrived at essentially the present understanding of the situation with respect to the number and positions of coal measures in Tasmania. He noted the occurrence, beneath Upper Palaeozoic marine beds in the Harefield Bore, of coal measures equivalent to the Mersey, equated the coal at Cygnet with that at Adventure Bay on stratigraphic and palaeobotanical grounds and went further to correlate the Adventure Bay and Cygnet coals with the Newcastle (Upper) Coal Measures of New South Wales. The main coal measures of southern and eastern Tasmania he placed as Mesozoic, rather than assigning them to a particular period, being unable to discover in them fossils diagnostic of any one of the Mesozoic periods in Europe (1888: 160). He had earlier published descriptions of some of the plants from the Triassic coal measures (Johnston 1887). Johnston (1888: 100-103, 166) followed Jukes and Selwyn in regarding the bulk of the dolerite as preCarboniferous and expressed this view in sections (e.g. opposite p.163). For example, he showed the coal measures abutting against dolerite southeast of Fingal (contra J. Milligan). A few years later, Johnston (1894: 172) removed the coal at Southport from the Mesozoic on the basis of fossil plants there and equated it (correctly) to the Adventure Bay and Cygnet Coal Measures. Johnston was a Scot who may well, as a boy, have been familiar with the work of Hugh Miller of Old Red Sandstone fame as he came from the same part of Scotland. Before coming to Australia he probably studied some geology at Glasgow University but he had no degree. His first position in Tasmania was as a clerk in the Launceston and Western Railway Co. While in Launceston he studied and wrote papers on the Tertiary sedimentary rocks and fossils of northern Tasmania. After moving to Hobart, where he became Government Statistician and Registrar-General, he studied the Tertiary but later, and more importantly, the Permian and Triassic rocks of southeastern Tasmania. He was commissioned by the Government of the day to write a book on the geology of Tasmania. The result was the classic A Systematic Account of the Geology of Tasmania published in 1888 . He continued to work on aspects of the geology of the State among many other activities for a couple of decades. His main contribution was the Systematic Account ... and his views on the coal-bearing sequences influenced work on these sequences for almost seventy years.

Twelvetrees (1902a: 67) regarded the Mesozoic coals as Jurassic except for that at Ida Bay (Triassic). 
The need to understand the coal resources of the State at a time of industrial development and hydro-electric power development led to the systematic survey and reporting of the coals and coalfields published as Geological Survey of Tasmanian Mineral Resources No. 7 by the Department of Mines (Hills et al. 1922). The stratigraphic framework used was essentially that of Johnston (1888), i.e. Lower Coal Measures and Upper Coal Measures of Permo-Carboniferous age and the Trias-Jura coals together with minor Tertiary lignites. Within the Trias-Jura eight coal seams, specified by Greek letters from Alpha to Kappa, were widely recognised and correlated, suggesting or assuming original continuity from one locality or another. This simple scheme cannot be maintained. Hills et al. (1922: 8-9) recognised the variability in form of the dolerite intrusions and noted that intrusion was accompanied by faulting. The importance of major and minor faulting in controlling the location of the coalfields and the mining practices in particular collieries was also recognised (ibid.: 10-11). The nomenclature of the coals used, i.e. anthracite, sub-anthracite, humites (including non-caking humic, caking humic and gas-making humic), humic kerogenites, kerogenites, sub-humites and lignites (or brown coals) was adopted on the basis of convenience (Hills et al. 1922: 13). In their discussion of the ash content Hills et al. (ibid::16-17) wrote of periodic flooding and wind transport; this seems to be the sole comment even hinting at the conditions of deposition of the coals. The treatment in this work was essentially economic and local, as was appropriate to its aim, but little opportunity was taken for comparative studies, e.g. between seams within the same succession, between Early Permian and Late Permian and Late Triassic coals, and between coals of the same age in different places. Proximate analyses were carried out on carefully produced samples of each seam. However, ultimate analyses, heat value analyses, were made and specific gravity determinations carried out on groups of samples from a district. The ultimate analyses were on dry whole rock, not dry ash free (daf) or dry mineral matter free (dmmf) basis, so direct comparison between coals is not easy. For each coal-bearing area the geology and topography as related to mining were noted, the stratigraphy within seams detailed and the tonnage of the reserves quoted. Some attention was paid to the history of discovery and exploitation in the various fields and in the State as a whole, but the history provided was both incomplete and, in places, inaccurate. Plants collected by members of the
Geological Survey during work on the Triassic coals were subsequently described by A.B. Walkom (1925, 1926), Director of the Australian Museum, Sydney, who correlated the coal measures with those of Ipswich, Queensland, and assigned a Rhaetian age to them. The coals were then assigned a Triassic age as reflected in Nye \& Blake (1938: 47-49). In a passing comment these authors referred to the lacustrine or swampy conditions of deposition of the Triassic coal measures, reflecting a comment by Johnston (1888: 162). In 1938, Arndell N. Lewis, a prominent local amateur geologist, and A.H. Voisey, a visiting professional geologist, recognised a volcanic component in the sandstones associated with the Triassic coals (Lewis \& Voisey 1938).

Dr John and Mrs Roma Dulhunty, from the University of Sydney, published the first palynological studies of Tasmanian coals (Dulhunty \& Dulhunty 1949) and showed approximate correlations of the Mersey and Cygnet Coal Measures with the Greta and Newcastle Coal Measures respectively but seem to have erred in regarding the Preolenna Coals as equivalent to the Upper Coal Measures. Subsequently Dr Mary Dettman (1961), then at the University of Cambridge, suggested a Rhaetian age for the Triassic coals on the basis of palynology. Later palynological studies of the Permian coals by Dr Elizabeth Truswell of the Bureau of Mineral Resources (in Truswell 1978 and Calver et al. 1984) have refined the correlations of the Mersey and equivalent coal measures and demonstrated that they are older than the Greta of New South Wales. Dr Geoff Playford from the University of Queensland (1965) showed that the Brady Formation and several other Triassic coals are Late Triassic, probably Rhaetian in age. Banks (1978) assigned a possible range from Anisian to Norian to the coal measures. Recently Forsyth (1984: 83), the first Tasmanian palynologist to study the coal sequences, has extended palynological work on the Triassic considerably and shown that the Triassic coal measures are Karnian in age.

The palaeogeography of the Permian coal measures received some attention from Banks (1962: 204-205, 211) who postulated deposition on extensive coastal flood plains with peat swamps. In the same volume G. Hale, Hydro-Electric Commission (1962: 224), suggested deposition of Triassic coals in a number of small lakes and Dr J.A. Townrow (1962: 230), a palaeobotanist at the University of Tasmania, suggested, by inference, peat swamps supporting large trees. Townrow later (1964) suggested the possibility that the 

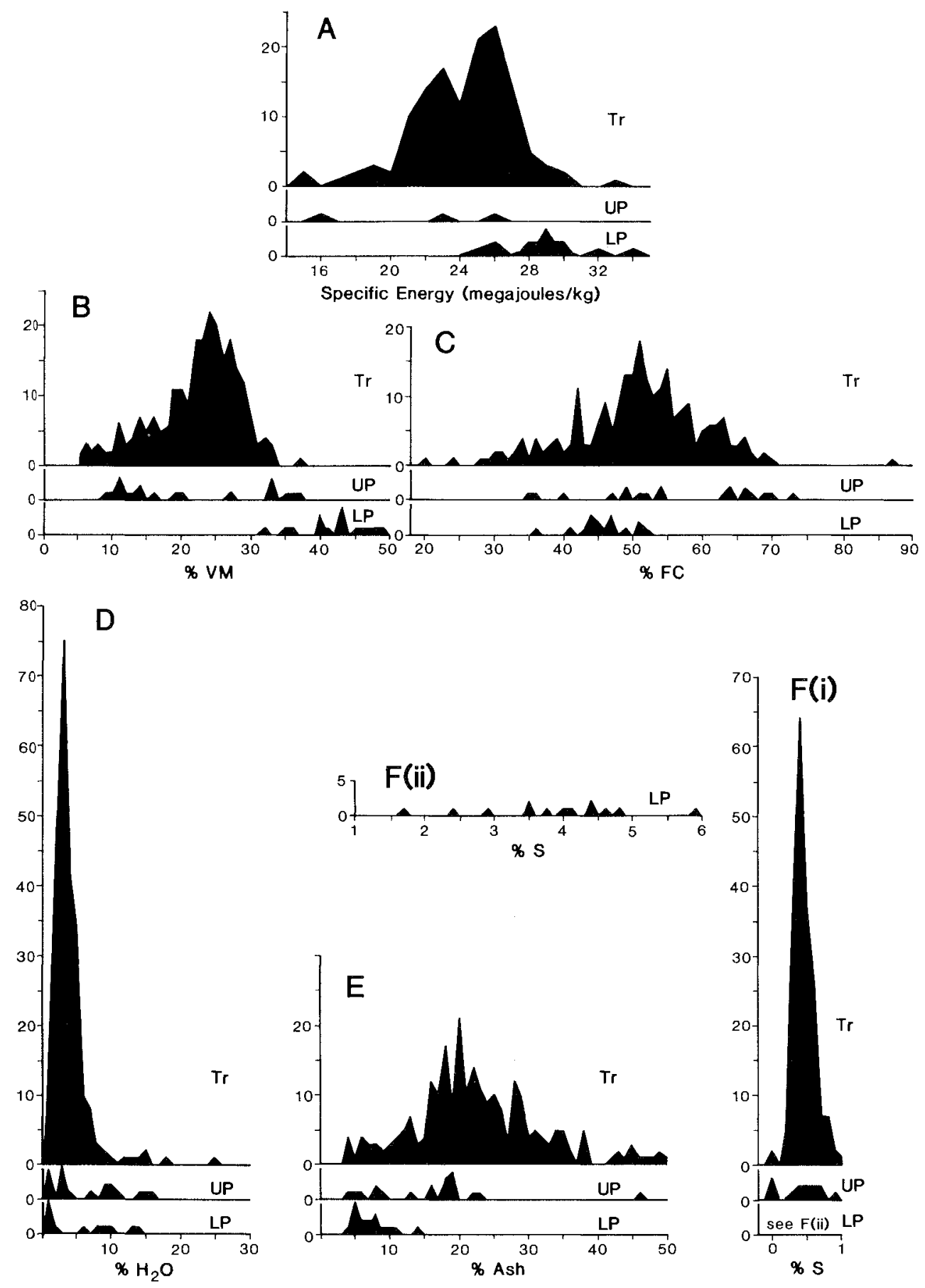


\section{TABLE 1}

Summary of Properties of Tasmanian Black Coals with comparative figures for NSW Coals

\begin{tabular}{|c|c|c|c|c|}
\hline Property & Age & Min. & Max. & $\begin{array}{l}\text { Modal } \\
\text { value }\end{array}$ \\
\hline Moisture $\%$ & $\begin{array}{l}\text { Triassic } \\
\text { Upper Permian } \\
\text { Lower Permian } \\
\text { Newcastle, NSW }\end{array}$ & $\begin{array}{l}0.6 \\
0.8 \\
0.5 \\
2.2\end{array}$ & $\begin{array}{l}25.4 \\
15.83 \\
13.58 \\
3.3\end{array}$ & $\begin{array}{l}3 \\
3 \\
1\end{array}$ \\
\hline Ash \% & $\begin{array}{l}\text { Triassic } \\
\text { Upper Permian } \\
\text { Lower Permian } \\
\text { Newcastle } \\
\text { South Coast, NSW }\end{array}$ & $\begin{array}{l}3.7 \\
8.67 \\
4.00 \\
7.6 \\
10.6\end{array}$ & $\begin{array}{l}50.00 \\
46.5 \\
13.72 \\
15.5 \\
21.6\end{array}$ & $\begin{array}{r}20 \\
19 \\
5\end{array}$ \\
\hline Sulphur \% & $\begin{array}{l}\text { Triassic } \\
\text { Upper Permian } \\
\text { Lower Permian } \\
\text { Newcastle } \\
\text { South Coast }\end{array}$ & $\begin{array}{l}0.03 \\
0.00 \\
1.7 \\
0.3 \\
0.28\end{array}$ & $\begin{array}{l}0.96 \\
0.9 \\
10.5 \\
0.5 \\
0.57\end{array}$ & $\begin{array}{l}0.4 \\
0.5 \\
-\end{array}$ \\
\hline $\begin{array}{l}\text { Volatile matter } \\
\text { (VM) } \%\end{array}$ & $\begin{array}{l}\text { Triassic } \\
\text { Upper Permian } \\
\text { Lower Permian }\end{array}$ & $\begin{array}{c}6.8 \\
9 \\
32.4\end{array}$ & $\begin{array}{l}37.5 \\
36.9 \\
48.9\end{array}$ & $\begin{array}{l}24 \\
11 \\
43\end{array}$ \\
\hline $\begin{array}{l}\text { Fixed Carbon } \\
\text { (FC) } \%\end{array}$ & $\begin{array}{l}\text { Triassic } \\
\text { Upper Permian } \\
\text { Lower Permian }\end{array}$ & $\begin{array}{l}19.52 \\
35.49 \\
36.0\end{array}$ & $\begin{array}{l}87.34 \\
72.58 \\
52.3\end{array}$ & $\begin{array}{r}51 \\
- \\
-\end{array}$ \\
\hline $\begin{array}{l}\text { Specific } \\
\text { energy } \\
(\mathrm{SE})(\mathrm{mj} / \mathrm{kg})\end{array}$ & $\begin{array}{l}\text { Triassic } \\
\text { Upper Permian } \\
\text { Lower Permian } \\
\text { Newcastle } \\
\text { South Coast }\end{array}$ & $\begin{array}{l}15.48 \\
16.2 \\
24.91 \\
33.05 \\
34.84\end{array}$ & $\begin{array}{l}33.1 \\
26.34 \\
33.8 \\
34.82 \\
36.05\end{array}$ & $\begin{array}{r}26 \\
- \\
-\end{array}$ \\
\hline
\end{tabular}

Moisture measured on air-dried samples (see Hills et al. 1922:23). Ash determined in the residue of dried coal from the moisture determination. Sulphur measured in air-dried coal by the Eschka method. Volatile matter measured by heating 60-mesh air-dried coal, determining loss in weight and subtracting moisture content from the loss in weight.

Fixed carbon value is the difference between 100 and the sum of the moisture, ash and volatile matter. Specific energy measured using 80-mesh coal.

Analyses of Triassic coals (close to 240 ) reveal that (a) $56.5 \%$ have moisture content of $3 \%$ or less; (b) $50 \%$ have an ash content greater than $21.5 \%$; (c) $58 \%$ have sulphur content of $0.4 \%$ or less; (d) the mid-point of the distribution of VM is $23 \%$; (e) the mid-point of the distribution of $\mathrm{FC}$ is $51 \%$; (f) the mid-point of the distribution of $\mathrm{SE}$ is $25 \mathrm{mj} / \mathrm{kg}$.

Sources: Tasmanian figures based on analyses plotted in figure 3 plus two analyses from Reid (1919); NSW figures (for washed coals) from Crapp \& Nolan (1975: 166), Wilson (1975: 212).

FIG. 3 (opposite) - Histograms of properties of Tasmanian black coals; properties along horizontal axes, number of samples along vertical axes; actual analyses (except percentage sulphur) rounded off to closest integer - thus numbers in range 19.51 to 20.5 rounded off to $20 ;$ in the case of sulphur in Upper Permian and Triassic analyses rounded off to nearest decimal point - thus 0.16 to 0.25 rounded off to 0.2 . (A) specific energy in megajoules/kilogram; $(B)$ percentage of volatile matter (from proximate analysis of air-dried coal); (C) percentage of fixed carbon (from proximate analysis of air dried coal; $(D)$ percentage of water (from proximate analysis of air dried coal); $(E)$ percentage of ash (from proximate analysis of air dried coal); $(F)$ percentage of sulphur, (i) mainly Upper Permian and Triassic, (ii) Lower Permian. Analyses from Hills et al. 1922 (table 1), unpublished reports of Department of Mines, Tasmania, by C.A. Bacon 1983-86 and from a report by the Hydro-Electric Commission on coal at Fingal, incomplete analyses and those with ash $>50.1 \%$ not included. 
climate under which the Late Triassic coal measures were deposited was cool temperate.

Although Milligan (1851) recognised that there were different types of sandstone associated with the coal now considered Triassic, he did not establish the correct stratigraphic relationships. This was done by Selwyn (1855: pl. 1, fig. 1) who noted a yellow sandstone below the coal and a greyish-brown sandstone associated with the coal. A geologist with the very newly formed Geological Survey, A. Montgomery (1891:15-16) recognised that the yellow sandstone was "very quartzose", the greyish-brown one "composed chiefly of fragments of a felspathic rock", and referred to the latter as "felspathic sandstone", a name which, although incorrect, has been replaced only in the last 25 years

Only recently has sedimentological study of the Triassic coal measures been attempted. These studies suggest deposition within a fluvial system of meandering streams under temperate conditions of pronounced seasonality (Morrison \& Bacon 1986). The presence of contemporary vulcanism, suggested by Lewis \& Voisey (1938), has been confirmed by the discovery of rhyolitic ash fall tuffs (Bacon \& Everard 1981). Petrological work on the Triassic coal itself was first done by Ms M. Smyth, CSIRO Division of Fuel Research (1979), who inferred from the the relative richness of the inertinite macerals that processes of decay were largely aerobic with flooding of bog surfaces with oxygenated waters. Later the Duncan Seam was assigned a palsamire origin with islands of trees growing in a swamp consisting predominantly of muskeg type vegetation, all under continuous permafrost (Smyth 1980). This very cold environment was not accepted by Morrison \& Bacon (1986), who postulated a vegetation of xerophytic woodlands growing on levee banks and higher parts of the flood plains, with broad-leaf forests of ferns, seed ferns, ginkgoalean and cycadalean trees in abandoned channels and the lower parts of the floodplains, and scouring rushes flourishing in the wetter areas. This general environment was suggested by Bacon (1986b) for Late Triassic coals at Mt Nicholas, Fingal, Merrywood and Avoca in northeastern Tasmania.

Maceral analysis of the Early Permian coals from the St Marys area by Bacon \& Calver (1986) and of the Preolenna coal by Bacon (1986b) led to suggestions of a back barrier depositional environment contrasting with the dry forest swamp environment common in the Late Triassic.

Very few vitrinite reflectance values of Triassic coals have been published, that on the Duncan
Seam (Late Triassic of Fingal) being the first (Smyth 1980: 177).

Although lignites have been known to occur in Tasmania since 1815 and have been reported from time to time in several places (see appendix 1) none have yet proved sufficiently economically attractive to mine on a long-term basis. Johnston (1888: 269-294) referred the lignites he mentioned to the Upper Palaeogene. The first good evidence on the age of the lignites was palynological (Cookson \& Duigan 1951) and later palynology by Cookson (1953, 1954, 1956, 1957, 1967 and in Gill \& Banks 1956) and Harris (1968) has allowed the recognition of Palaeocene, Eocene and MidTertiary lignites.

The highlights of the work on the geology of Tasmanian coals have been (a) Lhotsky's report with his postulation of environment of deposition in 1837 ; (b) the careful stratigraphic work by Joseph Milligan; (c) the structural work and recognition by Charles Gould of the presence in Tasmania of at least two coal horizons; (d) the establishment by Robert M. Johnston that there were three coal horizons; (e) the systematic survey of the coal resources by Hills and his colleagues; (f) recent work on palynology by Dettman, Playford, Truswell and Forsyth; (g) the inception of sedimentological work by Bacon and others; and (h) the application of maceral analysis by Smyth and then Bacon.

Most of the early work was done by visitors, often short term, and in many cases with little training in geology. Charles Gould was the first trained geologist to spend more than a few months in Tasmania and work on the coals. Loftus Hills was a Tasmanian with a degree in geology and one of his collaborators, A. McIntosh Reid, had received training in Tasmania under W.H. Twelvetrees. Other collaborators with Hills, P.B. Nye and H.G.W. Keid, had degrees in geology from Melbourne and Brisbane respectively but spent a long time in Tasmania. In recent years, work on coal in Tasmania has been dominated by trained geologists, born in or with long association with Tasmania e.g. C.A. Bacon, C.R. Calver, S.M. Forsyth and K.C. Morrison.

Except perhaps for the work by Gould on the stratigraphy of Tasmanian coals in the 1860's, work on these coals has been mainly of local significance. It has, in the main, been the application of ideas and techniques developed elsewhere, commonly years to decades before, to the Tasmanian scene. The derived and delayed nature of the work is hardly surprising in view of the local nature and relatively small scale of the Tasmanian 
coal industry. There is, however, scope for fundamental work in study of the petrology, sedimentology and palaeoecology of coals formed under cool to cold temperate, high latitude conditions.

\section{QUALITY OF THE COAL}

As early as 1824 comment was made on the poor quality of the coal at Richmond (Busby, Hobart Town Gazette 20 February 1824). Soon after coal from Saltwater River started being used for office heating in Hobart Town there were implicit complaints about its low quality (LSD 1/79:24). Strzelecki $(1842,1845)$ published the first quantitative analyses but, as noted earlier, some of his figures are suspect. De la Beche (1851) was not impressed with the coal because of its high ash content, as shown in his analyses, and the Select Committee on Coal (Horne 1864) reported that there was no coal worth exploiting as a State undertaking. A few analyses were published by Johnston (1888) and others were made from time to time of coal samples collected by officers of the Geological Survey of Tasmania. Hills et al. (1922: 28-30, table 1) brought together many earlier and original analyses; these showed the Lower Permian coals to be low in ash, intermediate in moisture and high in sulphur, with higher volatile matter (VM) and somewhat higher specific energy (SE) than the Triassic coals (fig. 3). Upper Permian coals had higher ash than those from the Lower Permian, about the same moisture content, mostly medium sulphur with some low and rare high sulphur coals, and lower VM and SE. These analyses made clear the high ash content and relatively low SE of the Triassic coals, which, however, had low moisture and sulphur contents. About $60 \%$ of Triassic coals were medium-sulphur coals in the sense of Hunt (1987: 14), 40\% low sulphur with some rare high sulphur coals. Figure 3 and table 1 show graphically and in summary the properties of Tasmanian black coals; they are based on the analyses in Hills et al. (1922) and in a series of unpublished reports of the Department of Mines prepared by C.A. Bacon over the last decade. There are probably still not enough analyses of Permian coals to allow of definitive statements but it seems unlikely that additional analyses will change the known distribution of the properties of the Triassic coals significantly.

A preliminary analysis of seam thickness suggests that in the Permian coals seams are thin, commonly less than a metre, and there are no seams more than $1.2 \mathrm{~m}$ thick. The great majority of seams in the Triassic are also a metre or less in thickness, but there are some more than $1.5 \mathrm{~m}$ thick (Morrison \& Bacon 1986, fig. 1) and a few, especially at the southeastern and northeastern edges of the present extent of the coal basin, which are more than $3 \mathrm{~m}$ thick, e.g. Catamaran - up to $10 \mathrm{~m}$ but with ash 30-40\%; Fenhope - $3.6 \mathrm{~m}$; Merrywood - up to $5.2 \mathrm{~m}$; Dalmayne - up to $7.35 \mathrm{~m}$ (largely carbonaceous mudstone); Fingal Tier - Seam B commonly $10 \mathrm{~m}$ thick (interbedded coal and mudstone), Seam C $16.89 \mathrm{~m}$ thick (also interbedded coal and mudstone) (Unpubl. Reps Dep. Mines Tasm.1983/08, 1983/22, 1983/07, 1984/10, 1983/ 46).

Recalculation of analyses in Hills et al. (1922, table 1) and in unpublished reports by Bacon and others (Unpubl. Reps Dep. Mines Tasm. 1983 to 1986), on a dmmf basis using the Parr formula (as in Ward 1984: 62), showed a fixed carbon percentage ranging from 43.27 to 96.28 . The results are summarised as table 2 and figure 4 . Lower Permian coals are predominantly high volatile bituminous coals (esp. High Volatile A), Upper Permian coals medium volatile to semi-anthracite, and Triassic coals sub-bituminous $A$ to anthracite especially medium volatile bituminous, using the ASTM limits for ranks (Ward 1984: 69). International and Australian standard classification of hard coals were not applicable because for the large majority of coals analyses did not contain sufficient
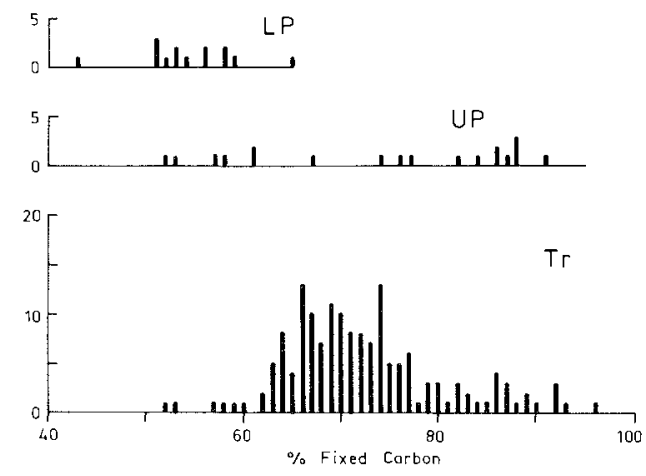

FIG. 4 - Histograms of fixed carbon content of Tasmania coals. Percentage calculated according to method described in explanation to table 2 from proximate analyses in Hills et al. (1922) and in unpublished reports by Bacon and others (1983 to 1986). 
TABLE 2

ASTM Rank* of Tasmanian Coals

\begin{tabular}{|c|c|c|c|c|}
\hline & & Lower Permian & Upper Permian & Triassic \\
\hline \multicolumn{5}{|l|}{ Anthracite } \\
\hline Anthracite & & & & 4 \\
\hline Semi-anthracite & & & 5 & 10 \\
\hline \multicolumn{5}{|l|}{ Bituminous } \\
\hline Low volatile & & & 4 & 17 \\
\hline Medium volatile & & & 3 & 67 \\
\hline \multirow{3}{*}{ High volatile } & A & 6 & & 17 \\
\hline & B & 4 & & 15 \\
\hline & $\mathrm{C}$ & 2 & & 5 \\
\hline Sub-bituminous & A & & & 2 \\
\hline \multirow{2}{*}{\multicolumn{2}{|c|}{ Rank uncertain ${ }^{\dagger}$}} & $\begin{array}{c}2 \\
\text { (FC 51,56) }\end{array}$ & $\begin{array}{c}7 \\
\text { (FC 52-67) }\end{array}$ & $\begin{array}{c}22 \\
\text { (FC 52-68.68) }\end{array}$ \\
\hline & & 14 & 19 & 159 \\
\hline
\end{tabular}

Highest FC

Triassic - Catamaran (96.28\%)

Upper Permian - Cygnet $(91.26 \%)$

Lower Permian - Preolenna (65.02\%)

FC below $60 \%$

Triassic - Bagdad, Fingal Tier, Buckland.

Upper Permian - George Town.

Lower Permian - Preolenna, Mersey, St Marys.

Lowest FC

Triassic - Buckland $(52.16 \%)$

Upper Permian - George Town $(52.29 \%)$

Lower Permian - St Marys (43.27\%)

* Rank determined from fixed carbon percentage on dmmf basis by applying formula

$$
\mathrm{FC}=\frac{\mathrm{fc} \times 100}{100-(1.08 \mathrm{~A}+0.55 \mathrm{~S}+\mathrm{M})}
$$

$\mathrm{fc}=$ fixed carbon from proximate analyses; $\mathrm{FC}=$ fixed carbon on dmmf basis;

$\mathrm{A}=$ ash content; $\mathrm{S}=$ sulphur content; $\mathrm{M}=$ moisture;

and from specific energy calculated on mmmf basis by applying formula (after Ward 1984:62,69)

$$
\mathrm{SE}=\frac{\mathrm{se} \times 100}{100-(1.08 \mathrm{~A}+0.55 \mathrm{~S})}
$$

$\mathrm{SE}=$ specific energy on dmmf basis; se = specific energy on air-dried coal.

Coals shown as "Rank Uncertain" are those with fixed carbon less than $69 \%$ for which specific energy values are not available.

Source: after Ward (1984: 62, 69). 
information to go beyond coal class (see Ward 1984: 70-73). The types of analyses available reflect the limited potential uses of Tasmanian coals.

A couple of points emerge from the recalculated figures. The Lower Permian coals had the lowest fixed carbon content and the smallest range in this content. Upper Permian coals have a somewhat similar range to that of Triassic coals, a range which extends well beyond that of the Lower Permian coals. The Lower Permian coals are from the margin of the Permo-Triassic basin and probably have had less load than later coals from nearer to the centre of the basin. Vitrinite reflectance data are also lower for these Lower Permian coals than for younger coals. Dolerite intrusions occur in the same areas as the Lower Permian coals, but not very close to the seams. The lowest fixed carbon content of Upper Permian coal is also in a coal very close to the edge of the basin and not immediately adjacent to a dolerite intrusion. No common factor can be seen in Triassic coals with fixed carbon below $60 \%$. Coals of anthracite rank in both Upper Permian and Triassic are from seams very close to dolerite intrusions.

Ultimate analyses of coals from a number of seams were also recalculated on a d.m.m.f. basis using the Parr Formula (Ward 1984: 62), this method being the only one usable with the data available. The results are tabulated as table 3 and plotted as figures 5 and 6 . Insufficient values are available to allow much interpretation. The carbon content is variable and is clearly influenced by metamorphism, both in Upper Permian and Triassic coals. Lower Permian coals are hydrogen-rich, Upper Permian hydrogen-poor and the Triassic coals mostly intermediate. When the hydrogen/ carbon ratio is plotted (fig. 6) none of the Permian coals is revealed as of normal humic type - they are either perhydrous or subhydrous. Some of the Triassic coals are normal but some of these also plot outside the range regarded as normal. The perhydrous coals may be liptinite-rich, as some Triassic coals are known to be, the subhydrous may be inertinite-rich as many Triassic coals are. Only in three cases can ultimate analyses be related to maceral analysis. The Kempton coal, shown to be subhydrous, has an inertinite to other macerals ratio of 2.28; the Mt Nicholas coals, either normal or just subhydrous, have ratios of 1.05 and 1.09

To summarise those properties of interest in utilising the coals, it can be said that the Lower Permian coals have low ash but high sulphur, a specific energy mode at $29 \mathrm{mj} / \mathrm{kg}$ and thin broken seams, whereas the Triassic coals have high ash but low to medium sulphur, a specific energy mode at $26 \mathrm{mj} / \mathrm{kg}$ and seams in excess of $1.5 \mathrm{~m}$ in many places and of $3 \mathrm{~m}$ in a few, as well as being more continuous than the Early Permian coals. Upper Permian coals tend to be more like the Triassic than the Lower Permian coals. The main coals of interest, the Triassic are medium-volatilo bituminous, but none of them have coking or gasmaking properties.

\section{THE MINING OF THE COAL}

The Mines

$$
\text { Richmond - ?1804, } 1841
$$

The diary of the famous British naturalist Robert Brown, who visited Van Diemens Land in late 1803 and 1804, carries a comment "Top of Grass Tree Hill to Coal Mine" followed by a bearing which indicates that the coal mine was that near Richmond. Brown arrived in the Derwent with Collins about 11 February 1804 and the entry quoted precedes one for 18 February. Perhaps, even at this early date, coal was being mined at Richmond. The household of the Reverend Robert Knopwood evidently used coal from the Coal River as a domestic fuel as early as 1805 . Knopwood records in his diary on 14 October 1805, and subsequently on a number of occasions, how coal was brought home from the Coal River.

Major Geils applied for a land grant including the site of the coal mine in 1813. The grant was refused as the site of mineral exploitation was reserved for the Crown. Bigge (1822) reported that no coal was being worked at Richmond.

An outcrop of coal was opened up by a Mr James Bonney on his property near Richmond and the mine offered for sale in 1840 (True Colonist 20 March 1840) apparently unsuccessfully. Fifteen months later (Hobart Town Courier 4 June 1841: 3) he attempted to float a company to mine the coal. He subsequently repeatedly asked for the loan of Government equipment including "boaring rods" and workers to work his coal (CSO 8/2/29522 June 1841, 10 August 1841, 13 August 1841) and even offered the mine to the Government (CSO 8/2/295 23 September 1841), an offer which was not taken up. A Government Surveyor, Jones, visited this mine and additional prospecting workings at Jerusalem in January 1844 , with a view to the 
TABLE 3

Carbon, Hydrogen and Oxygen in Tasmanian Black Coals

\begin{tabular}{|c|c|c|c|c|c|c|}
\hline Locality & Age & $\% \mathrm{C}$ & $\% \mathbf{H}$ & $\% 0$ & $\mathrm{H} / \mathrm{C}^{*}$ & $\mathrm{O} / \mathrm{C}^{*}$ \\
\hline Preolenna & LP & 79.73 & 6.47 & 9.96 & 0.97 & 0.09 \\
\hline Spreyton & LP & 62.55 & 6.61 & 28.26 & 1.27 & 0.34 \\
\hline Illamatta & LP & 70.4 & 7.4 & 19.54 & 1.26 & 0.21 \\
\hline Cygnet & UP & 85.86 & 4.58 & 9.88 & 0.64 & 0.09 \\
\hline Bruny & UP & 73.84 & 3.86 & 22.76 & 0.63 & 0.23 \\
\hline Catamaran & Tr. & 73.04 & 4.99 & 21.5 & 0.82 & 0.22 \\
\hline Hastings & $"$ & 75.91 & 6.03 & 18.61 & 0.95 & 0.18 \\
\hline Strathblane & $"$ & 69.47 & 5.71 & 25.24 & 0.99 & 0.27 \\
\hline Kaoota & $"$ & 64.87 & 5.69 & 29.57 & 1.05 & 0.34 \\
\hline (=Sandfly) & $"$ & 76.34 & 5.3 & 18.42 & 0.83 & 0.18 \\
\hline$"$ & $"$ & 79.65 & 4.68 & 16.76 & 0.71 & 0.16 \\
\hline Kempton $(1983 / 33)$ & $"$ & 82.7 & 4.50 & 10.82 & 0.65 & 0.10 \\
\hline York Plains & $"$ & 78.73 & 4.46 & 17.47 & 0.68 & 0.17 \\
\hline Buckland & $"$ & 57.65 & 5.02 & 37.50 & 1.04 & 0.49 \\
\hline Mt Christie & $"$ & 77.92 & 6.02 & 16.84 & 0.93 & 0.16 \\
\hline Merrywood & $"$ & 72.26 & 5.74 & 22.13 & 0.95 & 0.23 \\
\hline Saltwater River & $"$ & 80.31 & 4.41 & 15.67 & 0.66 & 0.15 \\
\hline Fingal & $"$ & 80.79 & 5.38 & 15.09 & 0.80 & 0.14 \\
\hline Mt Nicholas & $"$ & 65.31 & 5.76 & 29.37 & 1.06 & 0.34 \\
\hline$" \quad(1984 / 41)$ & $"$ & 78.3 & 5.15 & 14.6 & 0.79 & 0.14 \\
\hline$(1984 / 41)$ & $"$ & 81.6 & 4.93 & 11.4 & 0.73 & 0.10 \\
\hline Cornwall & $"$ & 75.16 & 5.15 & 20.07 & 0.82 & 0.20 \\
\hline Cardiff & $"$ & 69.44 & 5.63 & 24.95 & 0.97 & 0.27 \\
\hline Jubilee & $"$ & 71.45 & 5.77 & 22.81 & 0.97 & 0.24 \\
\hline Silkstone & $"$ & 74.76 & 5.49 & 20.23 & 0.88 & 0.20 \\
\hline Douglas River & $"$ & 73.84 & 6.13 & 21.72 & 1.00 & 0.22 \\
\hline$"$ & $"$ & 72.85 & 5.72 & 22.27 & 0.94 & 0.23 \\
\hline Dalmayne & $"$ & 67.73 & 5.38 & 27.7 & 0.95 & 0.31 \\
\hline & " & 69.81 & 5.61 & 26.21 & 0.97 & 0.28 \\
\hline Denison River & $"$ & 74.85 & 5.38 & 20.77 & 0.86 & 0.21 \\
\hline Mt Paul & $"$ & 79.39 & 5.70 & 16.3 & 0.86 & 0.15 \\
\hline Seymour & $"$ & 64.28 & 5.82 & 30.56 & 1.09 & 0.36 \\
\hline
\end{tabular}

$* \mathrm{H} / \mathrm{C}$ and $\mathrm{O} / \mathrm{C}$ are atomic ratios.

Sources: Analyses (except those indicated) recalculated from Hills et al. (1922: 28-30, table 1) on dmmf basis using Parr formula; Kempton and Mt Nicholas figures from unpublished Department of Mines reports as numbered.

Government taking over the workings. Bonney's mine at Richmond was described as a drift driven for $6 \mathrm{~m}$ on the dip of the seam, now full of water and abandoned. The coal was only $150 \mathrm{~mm}$ thick, with $1.2 \mathrm{~m}$ of shale above the coal (CSO 8/108/2279 2 January 1844). Jones considered that, although the coal was of good quality and situated close to Richmond, mining was unlikely to be profitable because of the water problem associated with the steep dip ("12 inches upon the yard" - approx. $20^{\circ}$ ).

\section{Macquarie Harbour - 1822}

Tertiary coal on the shores of Macquarie Harbour was unsuccessfully worked for a short time. The confession of the convict/cannibal Alexander 

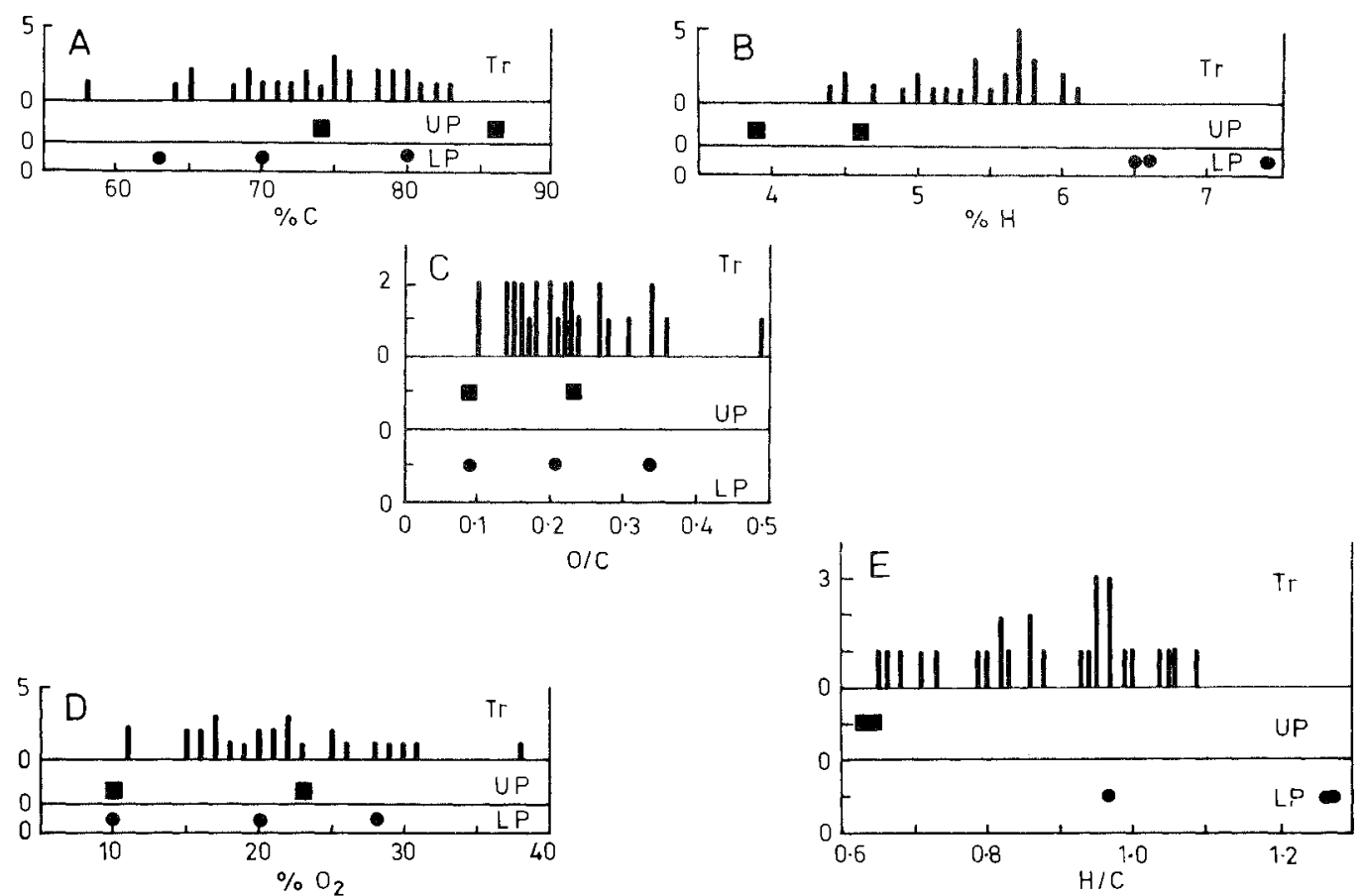

FIG. 5 - Histograms of carbon, hydrogen and oxygen values in Tasmanian black coals; based on values determined on dmmf (Parr formula) basis as shown in table 3. (A) percentage of carbon; $(B)$ percentage of hydrogen; $(C)$ hydrogen/carbon ratio; $(D)$ percentage of oxygen; $(E)$ oxygen/carbon ratio.

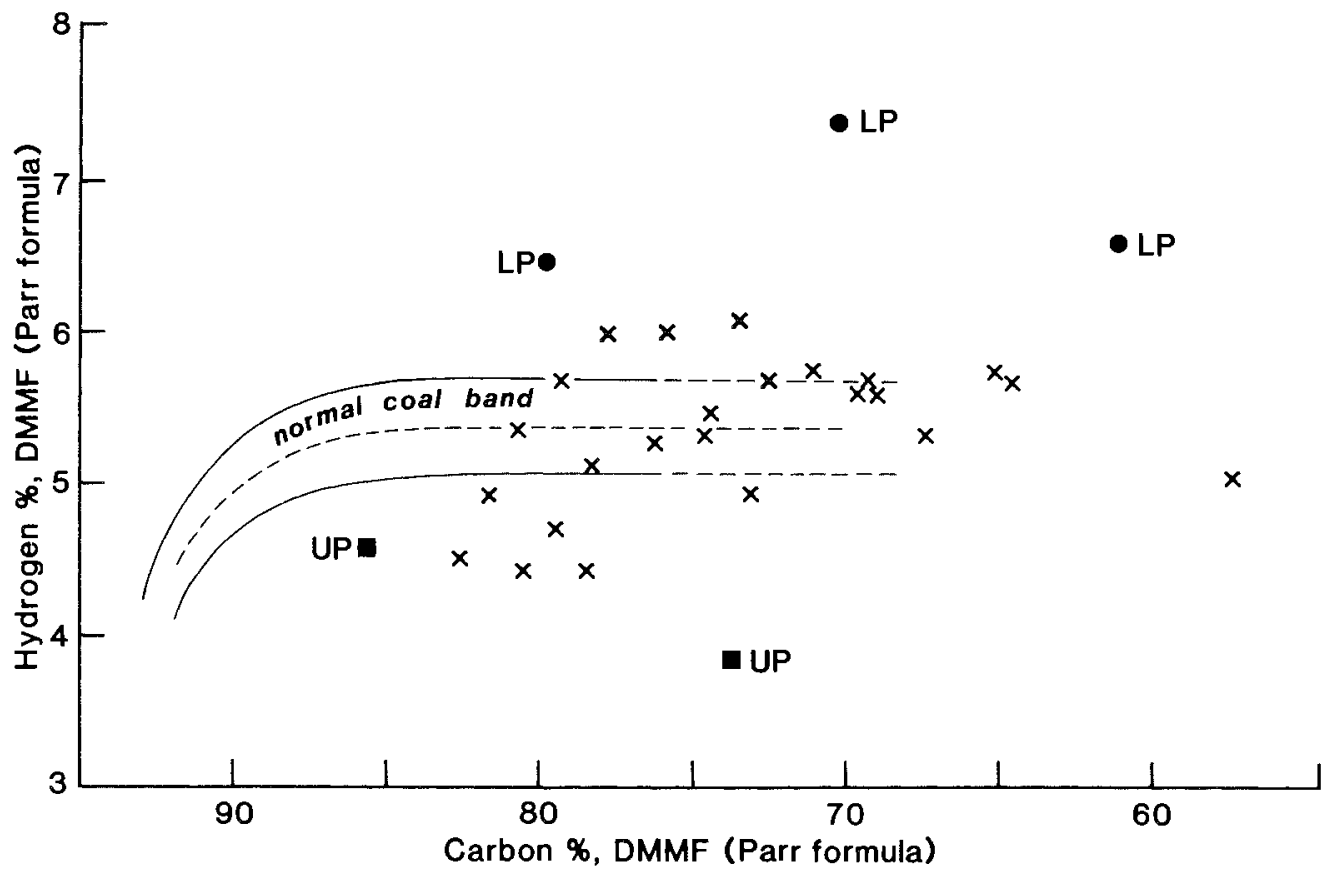

FIG. 6 - Plot of carbon and hydrogen percentages in Tasmanian black coals on Seyler's Coal Chart, based on data in table 3. 
Pearce (after whom the Pieman River is supposedly named, as he was a pieman by trade), made to Lieut. Cuthbertson, mentions having to call at the Miners Hut for Robert Greenhill, who was to accompany the escapees as navigator. Pearce, who escaped on 18 September 1822 , also mentioned the coal mining when interrogated by the Reverend Knopw ood (Sprod 1977):

"seven prisoners forcibly seized two boats at Kelly's Basin where they were employed in cutting timber under the charge of an overseer, and proceeded to the coal works where they were accompanied by Robert Greenhill ..."

The coal mine was at Coal Head (Julen 1976: 81). The Macquarie Harbour mining venture was unsuccessful and short-lived. The coal was picked up or dug up on the surface (Julen 1976:22) although a shaft had been sunk in search of coal prior to Pearce's 1822 escape (Dixon Library MS Q168 Evans - Norfolk Island Convict Papers 8). Some, sent to Hobart Town, was not very satisfactory but it was used on Sarah Island (Julen 1976:22). Lieut.-Governor Sorell wrote about it to the incoming Lieut.-Governor, Arthur, on 22 May 1824 (Julen 1976: 19):

"Good coal on which I relied has not been found, but from indications and from the coal formation in other places it is probable that the failure has arisen from want of scientific research."

It had not been appreciated fully enough that the Macquarie Harbour coal was brown coal not black coal as known elsewhere in Tasmania at that time. Sorell made a comment similar to that above "the want of professional research had deprived the local Government of the means of working it" in a despatch to Under-Secretary Horton dated 29 November 1824 (HRA III:583).

\section{Saltwater River - 1833 \\ Development of the mine}

The discovery of coal by surveyors Woodward and Hughes near Plunkett Point, Norfolk Bay, early in 1833 (prior to 23 May, O'Hara Booth Journal, Heard 1981: 158), was the result of instructions issued to them by George Frankland, SurveyorGeneral. His report to Governor Arthur (GO 33/16/ 264-265) of 29 January 1834 includes the phrase "after a careful search for coal". Frankland's instructions were in turn the result of his commission from Earl Bathurst conveyed through Hay to Arthur (HRA III (5):234).
Woodward was sent by O'Hara Booth, Commandant at Port Arthur, to "open a space into the mine" prior to 15 October 1833, when Booth reported on the coal in a letter (CSO 1/690/15052) and recommended an examination of the seam by a "regular miner" and the use of boring rods. In another handwriting, as an appendix to the letter, seems to be an instruction to be conveyed to the Chief Police Magistrate to use a Mr Lacey. Certainly by 31 October 1833, Matthew Forster, Chief Police Magistrate, was recommending to the Colonial Secretary that Joseph Lacey and four other convicts be sent to begin the mine excavations, Lacey having returned from an inspection (CSO 1/690/15052) of the coal (Forster to Arthur 31/10/1833, TSA). Lacey was "a practical miner at home" (Besford 1958: 136). O'Hara Booth in his journal noted "went to the mine" (19 November 1833) and by December of that year a shaft was down thirty feet $(10 \mathrm{~m})$ (Heard 1981: 166). The first shipment of coal from Saltwater River reached Hobart Town in the schooner Kangaroo on 3 June 1834. It fetched between $10 /-$ and $19 / 6 \mathrm{~d}$ per ton at a time when you could have bought about 40 loaves of bread (each $680 \mathrm{~g}$ ) for a $£ 1$ (TSA Wayne Index "Bread, price of"). The coal was not entirely satisfactory, as a letter from the Survey Office dated 6 June 1835 (LSD 1/79: 24) asked for wood to start the fire because of the stony quality of the coal. It was mostly used as a domestic fuel in Hobart although there were constant complaints regarding its quality. Denison (1870, Vol. 1: 38) remarked that the coal "answers well for the kitchen but is dirty and flies about too much to be used in the sitting room" (because of pyritic layers, Besford 1958).

By 1837 two shafts and one adit connecting with one of the shafts had been dug. Various "galleries" were driven off from the two shafts to provide working places. All extraction was done using the bord-and-pillar method, initially using both shafts and adits for access. Four cells, having the approximate dimensions $1 \mathrm{~m} \times 2 \mathrm{~m} \times 2 \mathrm{~m}$, were dug at the base of one of the shafts, and these nasty "cubby-holes" were used as punishment cells.

The Polish explorer, Dr John Lhotsky, visited the mine in February 1937; in reporting to the Commandant (CSO 5/72/1584), he noted the need for a survey of the mine and for better records (proformas of which he submitted), and suggested boring deeper or looking for better coal elswhere.

In March 1837, Sir John and Lady Franklin visited the mine and Lady Jane recorded in her diary a most detailed description of the workings, buildings, jetty and her general impressions of the 
place. She noted fires burning at the entrance to the coal mine (possibly these were to assist in ventilation; an old method of mine ventilation was to build a stone chimney and light a fire at the entrance of an adit or shaft, so the fire would create a draught, sucking air out of the adit/shaft and letting fresh air flow into a second entrance). Lady Jane proceeded into the

"farthest hole in the cliff (an adir) to right straight passage, sides supported by wooder posts, support cross rafters for keeping up flat roof with coal, get on here slightly stooping ... go on 78 yards $[70 \mathrm{~m}]$ to cached rock, a sort of small hall where at further end on floor is circular shaft to lower gallery with wheel on each side worked by men ..."

Production was then 35 tons per day from two seams. Coal was conveyed from the lower galleries by baskets which emptied automatically into small carts which then ran on rails along the adit to the jetty (Brand, in press).

Early in 1840, Lacey was withdrawn temporarily from the Saltwater River Mine to sink a shaft with other chosen convicts at Southport and again, later in the year, at Recherche Bay, despite O'Hara Booth's plea to Forster that such would lead to loss of production at Saltwater River and a short supply of coal through the winter period (CSO 5/224/5707).

William Dawson (see below), reporting to Josiah Spode, Assistant Chief Police Magistrate, on 21 July 1842 (CSO 22/59/909) made an estimate of the area underlain by coal and the yield (200000 tons $=203209$ tonnes), although some of that could not be recovered because of danger of collapse of the overlying penitentiary buildings. Because of the water problems then being encountered, and for other reasons, he suggested sinking a new shaft higher up the hill. He drew attention to the "necessity of a survey of the underground works being ... carefuly kept up".

A ten horsepower (7.5 kilowatts) steam engine, designed and erected by Alexander Clark, was installed on 5 August 1841 at a cost of $£ 600$ (CSO 22/4/56). Prior to this, coal was raised by a winch which used convict labour (Ford 1932), and two pumps for removing water from the workings were also manned by convicts. The mine headings were only $1.2 \mathrm{~m}$ high and the ventilation was poor. The roof, which was composed of shale, was supposed to be left, but was often taken to make the working conditions easier (Advertiser 9 August 1839:3).
Until 1840 convicis were sent to work at the coal mine as punishment, although only a small number of those at the mine actually worked underground. From 1840 to 1848 the convicts working at the mine were those on probation, and were released at the end of their probationary periods (Booth 1962). In September 1848 the mine was leased to Alexander Clark and C.M. McShane who were forbidden to use convict labour underground (CGF 10591/4 30 September 1848). In July 1851 James Fulton (who had been Assistant Superintendent at the mine from 1843-48) rook over the lease of the mines (CSO 24/-/6216) but this lease was short-lived. The Deputy Commissary (who supplied government depanmons with coal) wrote to the Colonial Secretary noting that after Fulton's lease had come into effect the Government was forced to take coal from New Town collieries (CSO 24/201/7508). The lease expired in 1856 and the new tender was won by William Nichols and John Thomas (Brand, in press). These two seem to be the only ones among the private owners who failed to "make the mine pay". The old workings were evidently worked out; a new shaft was sunk but no coal was found. The lease was re-advertised on 16 March 1858, and this time James Hurst, a former mine superintendent (see below) was the successful tenderer. The mine closed in 1877 .

\section{Some notable men involved at the mine}

William Dawson has been noted above as reporting on the Saltwater River Mine. He was a surveyor (probably with some training in civil engineering) and later had other and more sustained contacts with coal mining in Tasmania. After the discovery of coal on the Mersey he was engaged as surveyor and mine manager by the Mersey Coal Company in 1853 and subsequently played a prominent part in mining and other community activities in the Mersey district, especially near Tarleton and Sherwood (Ramsay 1958:121-126). He mined close to Dawson's Siding on the railway line southwest of Latrobe.

James Hurst started work at the Saltwater River Mines as an overseer (while on ticket-of-leave) in December 1840 . He was a coal miner by trade, transported for life for acts of highway robbery committed with his father in 1822. Both arrived in Tasmania aboard the Woodford in August 1828. Hurst was promoted to the position of Mine Superintendent and was apparently good at his job, as Governor Franklin insisted that William Dawson co-operate and avoid "clashing" with Hurst during the survey of the Mines Dawson was 
to und ertake. Count Strzelecki spoke to Franklin (CSO 22/59/909: 167) in high praise of Hurst's ability. His work was praised by Commandant Booth, after Hurst repeatedly requested a salary whilst he was a ticket-of-leave man (which was refused by Governor Franklin), then an increase in salary when he was working as a free man after his full pardon came into effect.

When a new shaft was sunk in 1843 , Booth wrote (CSO 22/22/880),

"... and I can only add that no one can deserve more merit for his unceasing zeal and exertion for the public service than Mr Hurst"

Hurst kept the lease of the mine until he died in 1877 , when the mine closed. The coal was virtually all worked out, and Hurst had in 1876 taken out leases at Sandfly, ordered a steam engine from the Excelsior Foundry; and quite probably intended moving his mining interest to this new location. The Sandfly venture also folded with his death. Whilst he arrived in chains, James Hurst died a wealthy and respected citizen of Hobart. During his years as a free man, he ran an inn at Swansea (1854), bought the Travellers Rest Inn (at Hobart), built a jetty at Swansea (1855-56) followed by the building of municipal and police buildings (1860-62) before moving to Hobart to live, while one of his three sons saw to the day-to-day running of the coal mine.

Zephaniah Williams, another name first noted in connection with the Saltwater River mine, subsequently had close associations with the coalmining industry, especially in the 1850 's. He was an innkeeper, mineral surveyor and coal merchant before his arrest and subsequent conviction on charges of high treason arising from Chartist plots for an uprising in Monmouthshire in November 1839; his death sentence was commuted to transportation to Van Diemens Land for life. Another Chartist, John Frost, sentenced with Williams, reported in a letter to his son in Bristol that "The Governor told us repeatedly that we (Chartists) were not sent to Port Arthur as punishment, but to fill certain offices..." (Hobart Town Courier 4 June 1841: 4) and they seem to have had some privileges. Our next news of Zephaniah is in a letter from William Jones to the Colonial Secretary on 25 January 1844 (CSO 8/108/2279) suggesting that Williams, "now a constable", be employed as an overseer at the Jerusalem Mines. During the interval 1840 to 1849 he pursued a number of occupations and received a ticket-of-leave in 1849. A shaft was sunk near the
Cascades Factory in March 1849 (Colonial Times 6 March 1849: 2) and subsequently others nearby, all unsuccessful; when later discovery of coal at New Town was reported (Hobart Town Courier 29 March 1851: 2; Hobarton Guardian 29 March 1851: 3) it was noted that Williams was closely connected with both endeavours. He became co-proprietor with R.J. Collins of the Triumph Coal Mine at New Town (Hobarton Guardian 17 September 1851: 1). Governor Denison, in a despatch to Lord Grey on 6 January 1852 (GO 33/75/5), noted that Williams had held his ticket-of-leave with good conduct for two years and had discovered coal in the neighbourhood of Hobart Town; Denison therefore supported Williams' application for a conditional pardon, which was granted on 27 January 1854. Late in 1851 , Williams visited the newly developed Mersey field; later he severed his connections with the New Town group and returned to the Mersey as manager, on behalf of a Hobart company of which he was a member, of a mine at Tarleton. He subsequently managed mines in the area, owned a store and a sawmill, and in 1862 became a publican, a business interest he retained until his death in 1874 (Ramsay 1958: 125, 126). It was rumoured (Launceston Examiner 24 April 1855) that Williams found the oil shale ("combustible schist", "dysodile", "tasmanite") in the Mersey area in 1851 , but this seems unlikely as Mr J.A. Wheeler of Port Sorell sent a specimen of the oil shale to the Royal Society of VDL, which was exhibited at the 9 April 1851 meeting. Williams was probably still active in the New Town area at that time. A.R.C. Selwyn visited the Mersey area in April 1855 (Launceston Examiner 24 April 1855: 3) to report on the coal and maintained that Williams was looking for coal beneath marine beds where it was not to be found. As noted earlier, Selwyn was correct for the particular mine but wrong in general. Williams' interest in coal continued into the 1860 's as he reported to a Select Committee on Coal Fields in 1864, having been in the Fingal area, St Pauls Valley, Swansea and Triabunna areas at least, in 1862 (Horne 1864).

\section{Southport - 1840}

A venture into coal mining was made in 1840 by Charles Swanston and eight others, who formed a syndicate and approached the Government of the day for assistance in sinking a shaft near Southport. The targets of this venture were seams in the Cygnet Coal Measures of Permian age (GO 25/8/76). The proposal by Swanston was that 
the Government provide the labour for sinking the shaft and operating the mine, with the company to provide materials; if successful, the company (The Van Diemens Land Coal Company) would lease the mine for 99 years at a cost of $2.5 \%$ of the profits (Executive Council Minutes 19 May 1840). The scheme was proposed again in 1841 and 1842 (Hartwell 1954).

The project drew satirical "extreme surprise" from the Colonial Times (11 February 1840:4) but the report does not seem to have been accurate, in view of a later letter from Franklin to the Secretary of State. Government favouritism was alleged in the same paper a week later (ibid:: 4) and a statement made that the overseer (Lacey) and four of the best miners from Saltwater River were working at Southport. This statement seems to be borne out by a letter of 10 February from O'Hara Booth to Matthew Forster (CSO 5/224/5707). The Lieut.-Governor (Sir John Franklin) noted in his letter to the Secretary of State (13 June 1840; GO 25/8/76) that after receiving the proposal he caused an investigation to be made, and the work noted in the Colonial Times may well have been that investigation.

As the report was favourable, the Governor had the matter considered in the Executive Council and granted a lease for 21 years (GO 25/8/76). A shaft was sunk in 1842 . Some 1300 tons of coal were brought to the Hobart Market (Colonial Times 17 May 1842). The Government Surveyor, Jones, claimed that most of this coal was obtained from the outcrop on the foreshore and not from any regular winning, so the coal was dirty (CSO 8/108/2279 13 July 1844). The mining operation was not profitable and collapsed, owing the Government $£ 4316$ ( $£ 1$ could buy about forty loaves of bread at that time) for the services of convict miners and an overseer, and for tools and stores supplied by the Government (GO 1/54 9 May 1844: 90).

The company had a brief period of paper prosperity in 1840 , when the shares rose from $10 /-$ sterling to $£ 10$ each. However, on the collapse of the company, the shareholders could not be traced and the Government was forced to forfeit the sum owing (GO 33/78 31 March 1853:713-717). The affair became known as the "Southport Swindle" (Booth 1962). Swanston was, at the time, one of two Attorneys-General and was later involved in coal mining on Schouten Island as well as many other industrial ventures.

\section{Jerusalem (Colebrook) - 1841}

As early as 1823 the presence of coal at Jerusalem was known (Besford 1958), and in 1831 this was being used as a reason for constructing a road from Richmond to Oatlands (James Gordon to Lieut.-Governor Arthur 4 November 1831: GO 33/21:372-373). James Clare rediscovered coal near Jerusalem (at Coalmine Bend) in 1841 (LSD 1/28/458 August 1841) and was employed to sink a trial shaft there on behalf of the Government (CSO 22/47/190 5 December 1841).

The Government Surveyor, Jones, was sent to inspect both the Richmond and Jerusalem workings in January 1844 and at Jerusalem recorded a seam $1.2 \mathrm{~m}$ thick, cropping out in Wallaby Creek (a tributary of the Coal River), and three other outcrops, one of which had been opened by an adit driven for $90 \mathrm{~m}$ and by a shaft $12 \mathrm{~m}$ deep (CSO 8/108/2279 15 January 1844). As a result of Jones' inspection, the Government decided to open up the Jerusalem mine and work started in March 1844 (CSO 8/10/2279 11 March 1844). Jones reported that two more seams had been opened up by August 1844 (CSO 8/108/2279 10 August 1844) but the quality of the coal was apparently too poor to warrant further investigation and the operation closed later that month (CSO 8/108/2279 21 August 1844).

Zephaniah Williams had harsh words to say about the Jerusalem coal he was instructed to inspect in 1862, writing to Falconer of the Public Works Department (Horne 1864):

“...I deem it incumbent to inform you of the state of the coal I am instructed to get 10 tons from. The seam is altogether three feet thick; but it will scarce produce two feet of clean coal. I never was more deceived than today; for on cutting into the seam I found it full of hard stone and of iron pyrites distributed throughout which in reality makes it good for nothing except for kitchen purposes, as it is quite impossible, without breaking the coal to pieces, to clean it. This is the coal there has been so much writing in praise of the most worthless seam of coal I ever saw. It contains some good coal. However I shall continue working it till I hear from you. In consequence of so much stone and iron pyrites scattered through it, it is very expensive getting and we can scarcely get tools to stand the cutting, in fact it is a seam that never will be worked for any purpose. Awaiting your answer with the utmost impatience." 
No mining activity resulted from this 1862 inspection. However, in 1879 work began again at Coalmine Bend, the mine being known as the Jerusalem colliery. This operation closed in 1890 , althou gh a small quantity of coal was extracted in 1894.

Closer to the town of Colebrook, a second area was worked from 1892 to about 1921. The mines were Bayntons (1892-97), Glen Leith (1902), Marialva ( $=$ extended Glen Leith workings 1902-1904), Colebrook (1911) and Tasma (formerly Bayntons, 1919-1921) (Dep. of Mines Ann. Repts 1901-21, Railways Ann. Repts 1901-2I, Dep. of Mines Underground Plans 282, 223, 380).

\section{Schouten Island - 1843}

John Woodward Graves (writer of "D'y ken John Peel") attempted unsuccessfully on 23 July 1840 to obtain from the Surveyor-General, Capt. Boyd, rights to coal on Schouten Island (LSD 1-46: 585-586).

Three years later Governor Franklin granted to Jesse and Isaac Garland a lease to mine coal on Schouten Island for six months from 16 September 1843 (CSO 22/84/1807: 149). The lease was extended for an additional six months, but a further extension was refused on the grounds that the Government planned to set up a probation station on the island (CSO 22/84/1807: 165-167) to work the coal. However the probation station was not built. Some 200 tons of coal from Schouten Island were on sale in Hobart in September 1844 (Colonial Times 27 August 1844). Milligan (1849: 8-9) commented on the mine workings as far as he was able in view of the deterioration.

The Australian Smelting Company was formed in August 1848 by Charles Swanston (of the Southport coal venture), with the object of procuring copper or other ore from Adelaide to be refined in or near Van Diemens Land. The company had a local board of directors and a committee in Adelaide (Hobart Guardian 3 July 1850). In 1848 offers were made by South Australian smelting companies to take 25000 tons (25 400 tonnes) of coal per year for $£ 1 / 1 /$ - per ton (Denison to Grey 18 May $1849 ; £ 1$ would then buy about 70 loaves of bread)

Swanston's smelting company formed the Schouten Island Coal Company in response to this offer, and began mining even before a lease was issued. Sixty tons of coal from Schouten Island were unloaded in Hobart in November 1848 (CSO 24/78/2496). A lease to mine coal for 21 years on payment of a royalty of 2 pence/ton (i.e. $1 / 120$ of $\mathfrak{£} 1 /$ ton) was issued in December 1848 . Interest in the venture declined, and no mining operation actually started in earnest.

\section{Douglas River - 1848}

With the offer from the Adelaide smelting companies, enquiries were made about coal south of the Douglas River, found by the Garlands in 1843. Governor Denison offered this coal on the same terms as the lease for the Schouten Island coal (Denison to Grey 18 May 1849).

Dr Joseph Milligan, who had inspected the Tasmanian coalfields in 1848 (Milligan 1849), set up the Douglas River Coal Company in May 1849 to exploit the seams south of the Douglas River. Under the terms of the lease, the payment of 2 pence/ton royalty was to be used by the Government to erect a wharf at Bicheno and lay a tramway to the mine (CSO 24/104/3280). Work commenced close to the Denison Rivulet, about $1.6 \mathrm{~km}$ from the sea. Two seams were mined from two shafts for a short time. Transporting the coal to Bicheno (a distance of $6.5 \mathrm{~km}$ ) was very costly, and after 800 tons had been raised, interest was transferred to an area closer to the coast (near Old Mines Lagoon), where four shafts and a number of bores were sunk. These workings were known as the Outer Mines (Gould 1861). Coal from this area was on sale in Hobart in 1850 , when ten tons were sold by auction (Hobart Town Courier 30 October 1850).

The company spent large sums building the tramway from Bicheno to the mines, as the Government failed to complete the job. The tramway was opened in December 1854. A 20 horse-power $(14.9 \mathrm{~kW})$ engine was erected in 1855 at the Outer Mines (Selwyn 1855). Despite the substantial investment, production was small (100-200 tons per month) and in 1858 the company failed (Hobart Town Courier 8 March 1858). Twenty-one young English colliers brought out especially to work the mine found their services not wanted (ibid. 2 March 1858).

Dr Milligan did not have an unruffled career as Chairman and Manager of the Douglas River Coal Company. He seems to have had technical if not also personal disagreements with one of the superintendents at the mine, J.Thomas. Thomas (1855: 1-TC622-33 THO) referred to the Chairman's "idiotic and impractical notions" as the cause of the Company's unsatisfactory financial situation. He maintained that Milligan had caused to be done more boring and shaft sinking than necessary and implied that Milligan did not 
understand the geology. In view of Milligan's published works on coalfields and his appreciation of the effects of faulting and dolerite intrusion on coal distribution that implication can be dismissed. On the other hand, if Thomas' statements about managerial matters not related to the geology are true, Milligan was not a good manager. At the Annual General Meeting of the Company, as reported in the Hobarton Mercury of 3 September 1855 (p. 2), there was, after the main business, a "desultory and somewhat personal discussion", a motion for the dismissal of Dr Milligan, followed by notice by Milligan's intention to resign and a vote of thanks to him for his "gratuirous services"!

\section{New Town - 1851}

Although coal had been known in the New Town area since 1823 (see earlier), it seems no mining took place for over a quarter of a century. A letter to Lieut.-Governor Arthur from a Mr Roberts (5 September 1831: CSO 1/120/3024) hinting at the need for Government finance to develop the coal received a cool answer, Arthur commenting

"it does not appear that mines could be worked to advantage by the Government ... I would gladly give encouragement to any private speculation...".

Mining in the New Town area began early in the 1850's (Hobart Town Courier 9 August 1851). Boyes noted in his diary for 19 April 1851 that he looked at the new mines (Boyes, R. Soc. Tasm. MSS R.S. 25/2C12). By July 1851 coal was being worked at Newlands (Proc. R. Soc. VDL II(1): 151) and other shafts had been or were being sunk. Zephaniah Williams discovered coal on Captain Spottiswood's property at New Town (Hobarton Guardian 29 March 1851: 3). In the Hobart Town Courier (9 August 1851:3) it was announced that the first load of coals from the shaft sunk by $\mathrm{Mr}$ Luckman at New Town had reached the town three days earlier. Just over a month later another source of coal (The Triumph Coal Mines) became available to the townspeople (Hobarton Guardian 17 September 1851: 1); New Town was the site of the mine, Williams and Collins the proprietors. This same Collins petitioned the Lieut.-Governor, Sir William Denison, on 27 January 1853, that a survey be made to "ascertain the extent of $\mathrm{Mr}$ Luckman's trespass" on the property rented by Collins from the Government (CSO 24/213/8097). The report on the trespass (CSO 24/213/8097) was inconclusive.
Later, interest lapsed and the activity did not last. During the 1870 's another burst of interest in coal mining occurred and a few small mines were opened (Thureau 1883a). Coal was sold for domestic purposes. The seams mined were very thin, and the quality of the coal was apparently poor (Krause 1884).

Hobart newspapers of 1 June 1897 recorded that mining had started again at New Town (near the top of Elphinstone Road) after an interval of fourteen years, and production records show that some coal was mined from the old Enterprise Mine in 1911 (30 tons) and 1912 (25 tons).

\section{Mersey Field - 1853}

The early history of the Mersey field has been dealt with at some length by Fenton (1881: Chapter XI) and by Ramsay (1958: Chapter VIII). A discrepancy will be noted between these works as to the date of discovery (1850 - Fenton: 1851 Ramsay). Mr B. Cocker, one of the discoverers according to Fenton, did not reach Tasmania until January 1851 (Launceston Examiner 8 January 185I: 10). The earliest unequivocal evidence is that a letter from the Assistant Police Magistrate at Port Sorell, J.A. Wheeler, concerning discovery of coal between the Don and the Mersey, was read at a meeting of the Royal Society of VDL on 12 March 1851 (Proc. R. Soc. VDL II(1):141-142). On 31 March 1851, Joseph Milligan was instructed to examine the find (CSO 24/261/5844) and by 14 May was able to exhibit a specimen of coal from the Don River and state the thickness of beds and relative position of the strata to a meeting of the Royal Society (Proc. R. Soc. VDL II(1): 147). He read a full report (dated 11 June 1851) to the Society on 9 July (Pap. Proc. R. Soc. VDL II(1): 90). The report by Crompton (Launceston Examiner 14 April 1856) of discovery in October 1851 is clearly erroneous on this point. Burns (1963, 1964: 88-103, 105-114, 222-245) and Dix (in Jennings 1979: 105-109) have given further information on the later history of mining in the field.

Mining started in the Bott Gorge area, but finished there in 1857 after massive expenditure on infrastructure and the spending of $\$ 20000$ on "fruitless endeavour". Two mines have operated in the Denny Gorge, seven near Tarleton, three at East Spreyton, five at West Spreyton and two near Sherwood, one each at Tugrah, near Caroline Creek, and at Nook, and fourteen near Dulverton. Most of these mines were worked for very short times and employed 2-4 people 
each. The last mine to close was the Illamatha No. 2, in 1962.

\section{Seymour -1861}

In 1861 mining began at Seymour, north of the illfated Douglas River Coal Mining Company's workings near the Denison Rivulet (CSD 4/6/40 11 Decenber 1861). A.H. Swift formed the Seymour Coal Mining Company in 1863 to mine coal, followed by the Australian Coal and Kerosene Company in 1868 , with the aim of retorting kerosene from the "slack" (waste) coal produced from mining. Some 2700 litres of oil were retorted from the coal and sent to Melboume to be refined (Tasmanian Times 18 June 1868); this suggests that some of the coal was alginite or liptinite-rich. Vast sums were expended on the building of a railway, storage bins and a long jetty. The first phase of mining lasted 17 years (Hills et al. 1922).

A new company, the Seymour Coal Mines Ltd, operated the original mine from 1923 to 1931 . A dip tunnel was driven to intersect the old, masonrylined circular shaft of Swift's mine. This enterprise collapsed when the $400 \mathrm{~m}$ long loading jetty was partially demolished by a storm in 1931. The dip tunnel was de-watered in 1959, and the coal mined was transported to St Marys by road. This venture closed in 1964.

In 1890 the East Coast Harbour and Coal Company's Act was passed by Parliament, allowing that company leases for 60 years for coal, stone and clay in return for the building of a railway from Seymour to Bicheno. Very generous rights to water, timber and minerals were included in the Act, but the venture failed; the railway was not built and no coal was mined.

\section{Fingal - 1864}

At Fingal, southwest of Mt Nicholas, coal had been discovered in the 1840's (Milligan 1849) but no mining started. The Government of the day financed the digging of an adit in 1864 ( $H A J$ 1867(95): 7). Mining on a small scale continued intermittently for some years. Activity was renewed in 1920 when the Fingal Coal Prospecting Syndicate drove two adits into the outcrop of the Duncan seam on Cat and Kitten Creek. These workings were acquired in 1942 by H.J. Yeates, who opened the Fingal Colliery. The Duncan Colliery opened adjacent to Yeates' in 1945 and the Tasmanian Mine opened in 1954, on the same seam and adjacent to the Fingal Colliery; work continued here until 1957. Minor activity in 1962-63 was halted due to poor ventilation.
The Fingal Colliery closed in 1965 , but was reopened in 1969 by the management of the adjacent Duncan Colliery, and the Fingal (Cat) tunnel was re-timbered to provide access to the Duncan workings following the closure of the Duncan tunnel. The Duncan Colliery is still in operation and in $1985 / 6$ produced 287000 tonnes of coal (run of mine), employing $80 \mathrm{men}$.

\section{Cygnet, Bruny Island, Gordon - 1879}

At Cygnet, on the slopes of $\mathrm{Mt}$ Cygnet and $\mathrm{Mt}$ Heeney, small-scale mining began in 1881, and continued in a haphazard and intermittent fashion until the 1940's. The Cygnet coal is of Late Permian age, as is the coal at Adventure Bay on Bruny Island. A very thin seam, approximately $0.5 \mathrm{~m}$ thick, was worked from a series of shafts and adits by W. Zschachner over the period 1879 to the early 1890 's at Adventure Bay. Zschachner had previously held mining leases in the New Town coalfield. At Gordon, a $\mathrm{Mr}$ Abbot opened up an outcrop of coal on the foreshore (EN 195100), calling the adit the Rookwood Coal Mine. Abbot tried to interest the Victorian Chamber of Commerce in his coal (LSD 1/48/310) and complained bitterly in 1879 that he could not compete with the mining at Adventure Bay (LSD $1 / 48 / 214$ ).

\section{Sandfly (Kaoota) -1876}

James Hurst, lessee of the Saltwater River Mine, took out the first lease in the Sandfly area in 1876 . With his solicitor, Lucas, he petitioned the Government (HAJ 1877 (33): 28) asking to be given land in return for building a tramway to North West Bay. The coal was opened up by means of an adit, work on the tramway had started and a locomotive had been built by Clark at the Excelsior Foundry especially for the project when Hurst died in July and the project ground to a halt. Prospecting work continued for years and in 1906 an extremely elaborate tramway was built from Kaoota to Margate by the Sandfly Colliery Company; it had ten large wooden bridges in a distance of $19.5 \mathrm{~km}$ (Whitham 1973). This company collapsed in 1907 , having produced only 8500 tons of coal. The tramway was taken over by the Tasmanian Wallsend Colliery Company which operated the Wallsend Colliery until 1910 . Since then, a number of syndicates have worked the field, usually calling their workings "the Sandfly Colliery". New adits were dug as old ones were abandoned and the name was transferred to the "new workings". The last mine in this field closed in 1971 (Threader 1972). 


\section{Avoca area -1882}

Coal was discovered in the Avoca area before 1845 but the first lease issued was for an area on the headwaters of Storys Creek (to J. Lamont in 1864); however, no mining followed. An adit was dug into this seam in 1882 by a Mr R. Stevenson (Dickinson 1945), but the distance from Avoca was too great for the venture to be successful. A thin seam of coal was found near Mangana (in the Mersey Coal Measures correlate) during shaft sinking for gold in 1863.

Around the slopes of Mt Christie coal was found in 1902. Minor prospecting workings known as the Buena Vista mine later became the site of the Excelsior (Stanhope) colliery, which operated from 1923-57. Extraction was mostly by the bord-andpillar system, although the longwall system was adopted briefly in 1944. In 1960 a bushfire swept across the mine site, and the seam outcrop at the portals caught alight. The old workings are still smouldering, and parts of the ground surface over the mine workings have collapsed. The New Stanhope Colliery, $1.3 \mathrm{~km}$ north of the (old) Stanhope, opened in 1957; a washing plant was installed in 1959 and mining continued until 1973. The Mt Christie Colliery was opened in 1959, in the vicinity of older prospecting adits on the southern flank of Greenstone Hill; it produced about 1800 tonnes of coal per year, but closed in 1965. Recently a new mine has been opened in this area, the Fenhope Colliery, which opened in 1980 close to the (old) Stanhope workings. The mine is owned and operated by Mr D. Fenton; the seam is $3.6 \mathrm{~m}$ thick and mining is all done by hand, the coal being wheeled along an impressive wooden gantry to a large wooden storage bin.

A reward lease was issued in 1917 to J.B. Dean and F.R. Davis for discovery of coal near Coal Mine Crag on the Ben Lomond Plateau; this coal has been "mined" by skiers for use in nearby huts.

\section{York Plains - 1883}

Coal in the lower Midlands area was described by Gould (1869). Mining at York Plains started around 1883 and continued until 1947. The coal was sold mainly for use in hop kilns. Mining was done by hand on a modified (step) longwall system.

\section{Mt Nicholas Range - 1886}

While coal seams had been known to occur in the Mt Nicholas area since the 1840 's, no real mining occurred there until 1886. Minor prospecting works extracted some coal in the 1840 's and tests of the coal were made by the railways in the early 1880's. However, high costs of transport to a suitable market precluded this field from being worked, until a railway line from $S t$ Marys to Conara (then known as Corners) was opened in June 1886. The Mt Nicholas area is the premier coalfield in the State, and mining has been virtually continuous in this field since 1886, when the Cornwall Colliery was opened by the Cornwall Coal Company. Two years later the Mt Nicholas Colliery was opened nearby by a rival company The Mt Nicholas Coal Co. Pty Ltd; having been bought by the Cornwall Coal Co., it closed in 1958, the Cornwall Colliery closing in 1964 due to loss of markets. The Jubilee Colliery, much smaller than the first two mines, was worked from 1897 to 1902 and from 1920 to 1960, and the Cardiff from 1901 to 1914. In 1980 the Cornwall Coal Company opened the Blackwood Colliery, close to the old Cornwall workings. The Blackwood Colliery produced 202000 tonnes of run of mine coal in 1985/86. A new portal west of the main one and known as the "Blackwood West" opened in 1988. A small area of coal was removed by open-cut means to ensure that the portal would be started in firm, unweathered ground.

\section{Hastings - 1888; Ida Bay - 1892; \\ Catamaran - 1900: Strathblane - 1910}

Coal has been known in this general area since 1793 (South Cape Bay) and some workings on the northeastern shore of Recherche Bay were noted in 1838 (see earlier). It seems likely that Lacey, Superintendent at Saltwater River, did open a shaft in the area late in 1840, despite O'Hara Booth's plea to Matthew Forster that his withdrawal with that of other experienced miners would result in loss of production at Saltwater River and a short supply through the winter period (CSO 5/224/5707). An analysis of coal from a small mine at Hastings was given by Johnston (1888). Prospecting at Hastings continued until 1923 when the lease expired.

A small mine was worked at Ida Bay in 1892 as part of a cement-making project (Twelvetrees 1902c). The project did not eventuate and the mine quickly closed. At Catamaran, south of Ida Bay, coal was discovered in 1900. A number of companies worked mines in this field, the last closing in 1939 (Whitham 1983). Most of the early work in this field consisted of the construction of enormous bins, expensive tramways and jetties, leaving little capital for mine development proper. Most of the early investing companies in this area 
collap sed due to over-spending on infrastructure. Workings in this area included Hoods (1900-10), James (1910-12), New Main Shaft (1913-14), Mack enzie (1923-30), Ribbon (1931-34), Anthracite (1927) and Stronach Tunnel (1934-39).

Coal was discovered at Strathblane, north of Ida Bay, in 1908. Prospecting work was carried out for some years, and a small-scale mining operation extracted coal from 1926 to 1933. The average seam thickness was about one metre (Keid 1952).

\section{Preolenna -1903}

Very thin seams of coal were mined at Preolenna, on the northwest coast, early this century. Following the discovery of outcrops of coal in 1903 by track-cutters, small-scale mining of the coal occurred intermittently from 1921 to 1931 , with two mines, Preolenna and Torbanhill (Meunna) being opened. The Meunna Mine was, in 1919, a series of prospecting workings called "The Great Fitzroy Coal Mine". The use of the name "Torbanhill", reflects on the boghead nature of the coal, there being a similarity with the oil shale of Torbane Hill, near Edinburgh, Scotland. Considering that the seams were no more than $0.5 \mathrm{~m}$ thick and dipped at up to $25^{\circ}$, the attempts at mining were certainly optimistic. The coal is of Early Permian age and the Preolenna Coal Measures in which the seams occur may be correlated with the Mersey Coal Measures further to the east.

\section{Dalmayne - 1914}

The Dalmayne coalfield lies southeast of $\mathrm{Mt}$ Nicholas. Outcrops of coal had been known since before 1860 (Gould 1861a) and reward leases were applied for but not issued in 1887. No mining eventuated until the ambitious Dalmayne Colliery Company was floated in 1914. The company built an aerial ropeway from the mine site to Piccaninny Point, a distance of $5.5 \mathrm{~km}$. A jetty $180 \mathrm{~m}$ long was built at Piccaninny Point for loading the coal. Substantial mine development work occurred and the mine was officially opened by Sir Elliot Lewis, Minister for Mines, on 24 August 1917. However, a shortage of boats for shipping the coal (owing to the war) hampered progress and in 1918 the jetty was washed away in a storm. The mine was forced to close, but reopened in 1939 under new management. Coal was transported by road to St Marys until the operation closed in 1953.

\section{Langloh -1938}

In the Derwent Valley, near Hamilton, the Langloh (Lawrenny) Colliery began operations in 1938, continuing until 1963. Coal had been known from this locality since 1849 (see appendix 1 ) and minor prospecting activity occurred in the 1890 's (Montgomery 1894). Small reserves of coal adjacent to the old colliery and suited for open-cut extraction have been evaluated recently.

\section{Merrywood - 1945}

Coal was discovered at Red Rock, near Merrywood, by Zephaniah Williams in 1864 and rediscovered in 1909. Mining eventually began at Merrywood (the Merrywood Colliery) in 1945, with coal being extracted by both underground and open-cut methods until 1963. A washing plant was installed in 1957 and coal hauled by road to the railway at Avoca. In recent years open-cut extraction on a small scale (1500 tonnes/week) has resumed for a few weeks each year; this activity is likely to be for a limited period only.

\section{SUMMARY OF THE INDUSTRY}

Some quantitative aspects of the mining industry are presented in a series of graphs and a table. The distribution of the discoveries of coal in space and through time is shown in figures 1 and 2 and has already been discussed. Not unnaturally the distribution of time of initial opening of mines is delayed relative to the discoveries but, like the distribution of discoveries, shows some peak periods (fig. 2 A(iii), B(iii) and appendix 2).

The first period of intense activity was from 1840 to 1859 , the second in the 1880 's, and there was a long third period from 1900 to 1939 , with the highest rate per decade in the 1930's. The first period covered a time of general population increase (with a distinct slump in the 1850's due to emigration to the Victorian gold fields (Johnston 1901)). The Government saw the possibilities of export, such as occurred with New South Wales coal, and of useful employment of convicts. During this period, and earlier, convict labour was used in mines at Macquarie Harbour, Saltwater River, Jerusalem (Colebrook) and Schouten Island, with minor use at Southport and Recherche Bay. The increasing use of coal as a fuel for steam locomotion accelerated the opening of mines. Thus, the first steamer using coal plied the Derwent River as 
a ferry from Hobart Town to Kangaroo Bay beginning in 1832 (Colonial Times 10 September 1832). A vessel such as this, with an Australian. built marine engine, which had started on the ferry run in 1834 (Colonial Times 12 September 1834), drew admiration from Charles Darwin when he crossed the river early in February 1836 (Barlow 1933: 388-389). The colonisation of Port Phillip provided, at least temporarily, an opening for export sales; these reached their zenith in 1858 when 2670 tonnes were exported, almost $96 \%$ of it from Launceston and probably originating in the Mersey fields, where eight companies were supplying coal to the Melbourne market (Booth 1962:37). A peak in the number of producing mines was reached in 1855 (fig. 2C). Another factor increasing the rate of opening of new mines or reopening earlier mines was the demand for coal for smelting copper in South Australia. This demand led to the establishment of a company, Australian Smelting and Coal Company, in 1848, but this company was not very successful in mining coal (Booth 1962: 29).

The population of Tasmania did not rise as rapidly in the 1860 's and 1870 's as it had previously. Unlike the situation in other parts of Australia, which experienced boom conditions, stagnation affected Tasmania (McGhee 1969: 138). Further, Tasmanian coal lost the Victorian and South Australian markets in competition with cheaper and better New South Wales coal (Booth 1962: 93). The number of mine openings dropped after 1860 , but the number of operating mines gradually rose from 1860 to 1874 (fig. 2C). The effects of the opening of the Launceston and Western Railway in 1871 and of the Hobart to Launceston Line in 1876 caused some increase in mine openings even prior to the opening of the Conara Junction to St Marys line in 1886. The latter had a major effect as this line provided access to the Fingal-Mt Nicholas fields with the thicker and more continuous seams. More mines were opened in the 1880 's than in any prevous decade and the total number of mines operating reached another peak in 1889 (fig. 2B(iii), C). Stagnation in the Tasmanian economy in the 1880 's was followed by Australiawide depression in the 1890 's. The number of mine openings and the total number of mines fell in the ten years ending in 1900. Despite the general depression the mining towns of the South Esk Valley - Fingal, Mt Nicholas, Cornwall and St Marys - grew (Blainey 1954: 65) and the Huon area did well. In the Huon the first timber mill had opened at Recherche Bay in 1860 (Centenary of Settlement in the Huon. Huon Newspaper Co.,
Franklin 1936); there were many mills in the area in the 1880's and in 1890 there were 17 sawmills in the Franklin district (Walch's Almanack 1890: 328). Here, the activities associated with milling led to the discovery of coal outcrops and the excellent steamer services provided accessible transport for any coal produced. New mines were opened near Cygnet, Catamaran, Hastings, Ida Bay and Strathblane from the late 1870's to the early 1900 's. Thus there were more mines producing in Tasmania in 1910 than at any previous time (fig. 2B(iii), C). The number of mines open and the number of new mines fell over the war period and immediately thereafter. The 1920's were years of depression in the coal industry in Australia and production remained low. Tasmania was not so seriously affected as other parts of Australia, due to a local high price of coal and a major industrial strike in New South Wales (Shaw \& Bruns 1947: 90). The depression of the 1930's was a period when the rate of opening of new mines was the highest in the history of Tasmania up to and including the present day. The peak in the number of mines was reached in 1938 (fig. 2C). Most of the mines opened (or reopened) in the 1930's had short life spans (fig. 7B). At least ten small mines opened and closed in the Mersey coalfield alone. It seems likely that the peak of openings in this decade resulted from men put out of regular work seeking a paying "fill-in" activity. Production (fig. 9) did not increase greatly compared with the massive increase in the number of mines. After 1940 the rate of opening of mines and the number of mines operating has decreased more or less consistently and markedly. Part of the decrease can be attributed to the progressive replacement of coal by oil, and the opening of new mines in the 1980's results from the high price of oil. Part of the decrease (fig. 2A(ii), C) can be attributed to the high capital outlay needed in recent years to open a mine. No longer are a pickaxe and shovel, a light, and a horse and cart or small truck generally enough.

It is interesting to examine the longevity of Tasmanian coal mines as revealed from offical production figures (fig. 7). As seen from figure 7A, almost $40 \%$ of mines have recorded production for only one year and $63 \%$ have had productive lives of five years or less. The decades ending 1910 and 1940 (especially the latter) were particularly notable for the short lifespans of mines started in the decade. Two fields stand out as having more longer lived mines than others (fig. 8) - - the Mersey field working on low ash, high specific energy Lower Permian coals, and pre-eminently the 


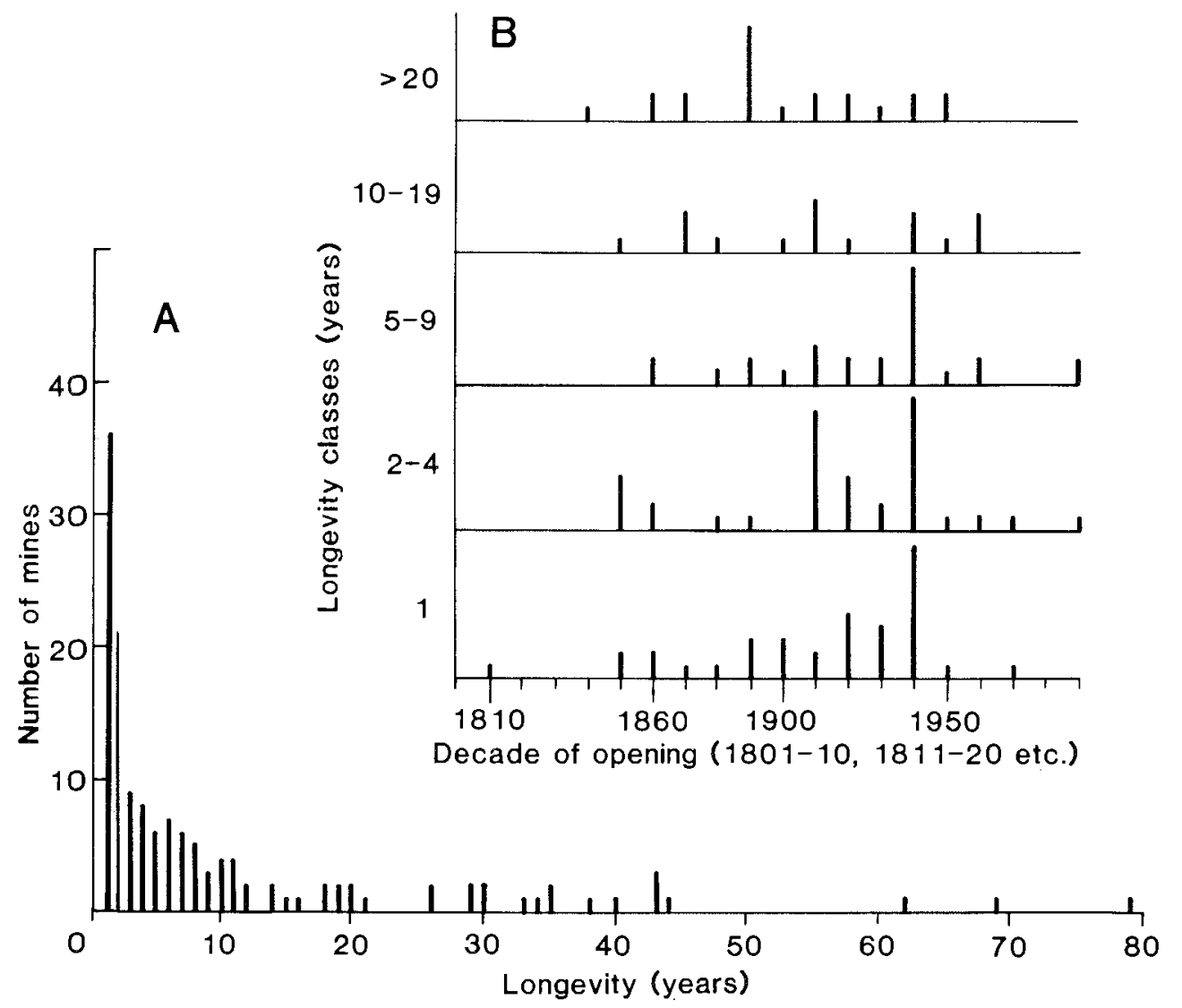

FIG. 7 - Longevity of Tasmanian coal mines; based on information in figure 6. (A) distribution of longevity in years; vertical bars show number of mines having longevity indicated by position on horizontal axis; $(B)$ distribution of longevity of coal mines according to decade of opening.

Fingal-Mt Nicholas field working on thick and more continuous seams of Triassic coal, albeit with high ash content and relatively low specific energy. The Cornwall Mine has had the longest working life (about 78 years) and the nearby Mt Nicholas Mine one almost as long.

\section{Production and Employment}

Booth (1962: 98) advanced a number of factors affecting a coal-mining industry. The factors include coal quality, the size, continuity and position of seams relative to the ground surface, a large market and cheap transport. Lack of several of these factors has ensured that the Tasmanian coal-mining industry has never been a major one in
Australia-wide terms, as shown graphically for the period after 1900 by Elford \& McKeown (1947: fig. 5). The Mersey coals are approximately equivalent in quality to those of New South Wales but the seams are thin and discontinuous. The seams of the Triassic coals are thicker and more continuous than those of the Mersey but the quality is not so high. Mining conditions are ideal in few places, faulting and dolerite intrusion causing difficulties. Initially transport was a difficulty but this factor was partially overcome with the advent of steam-driven vessels and railways. Even now, transport can provide problems. The local market for coal has always been small and export has been limited because of competition, especially with coal from New South Wales which has had the dual advantages of a much larger home market and 
better quality than Tasmanian coal and also, it might be said, better mining conditions.

Coal production has not always paralleled either the rate of discovery or mine opening, or the total of miners operating. The first peak in discovery and exploitation in the 1850 's preceded offical records. It is known that production reached a peak of 10600 tonnes at Saltwater River in 1840 (Booth 1962: appendix A) and that coal exports reached a maximum of over 2670 tonnes in 1858 (Booth 1962: appendix B). Coal production, like discovery and exploitation, stagnated or dropped slightly from 1866 to 1886 after which it rose to a peak in 1889-90 (fig. 9). Subsequently, the depression of the 1890's is reflected in production decrease and the recovery therefrom in rising production rates until 1910-11. The rise in production paralleled the rate of discovery and of mine openings and the peak corresponds to the peak in the number of mines open at the end of a decade (fig. 2B(iii), C). The activity in the industry in the late 1920's and early 1930 's is reflected by production figures as well as mine openings and mines operational (fig. 10). After 1940 there is little relationship between the production figures and the factors operating earlier. Increased industrialisation in the State led to increased demand and production until the late 1950 's, after which replacement of coal by oil as a heating fuel in many industries reduced demand and production in the mid-1960's to the lowest figure since the 1920's. Increase in the price of oil reversed the trend away from coal burning, and production has increased very dramatically since. This increase, and the possible need to supplement hydro-electric generation of electricity, fostered work by the Geology Section of the Hydro-Electric Commission (H.E.C. 1967) and the intense exploration programme of the 1970's and early 1980's (Tasmania, Director of Mines Reports 1974 et seq.).

It will be seen from fig. 10 that the number of operating mines since 1900 has not been high and that many of the mines employed only a few men. A tendency for the number of mines employing more than 16 people (fig. $10 \mathrm{C}, \mathrm{D}$ ) to rise until the early 1960 's is also revealed, i.e. the number of "big" mines increased. Rises in production after the low of the 1960 's seem to be associated with some rise in employment (fig. 10) but productivity has clearly increased. The peak of employment (over 400 people) was reached in 1929-30. At that time it was between three and four times the present number but production was only a third to a quarter of the present level. Productivity improved at the time of the 1950's production peak. There were

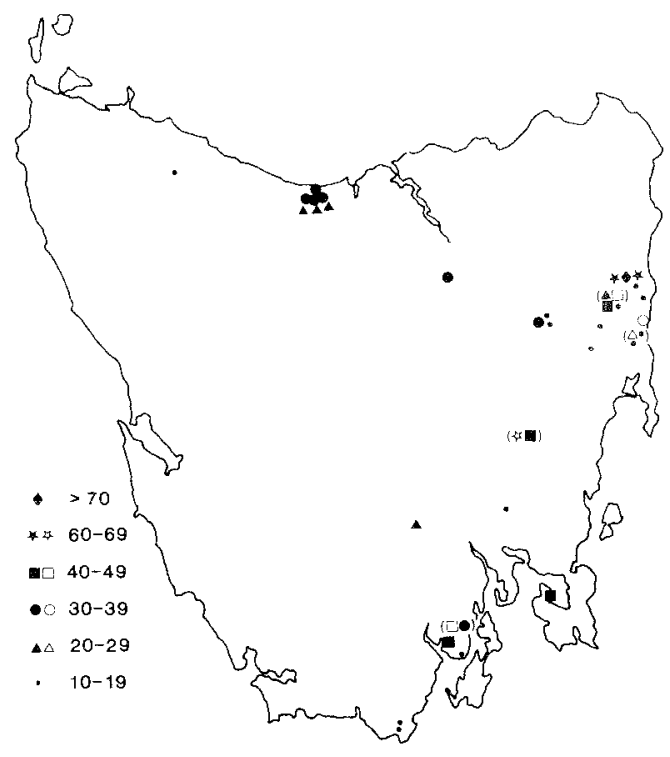

FIG. 8-Geographical distribution of longevity of Tasmanian coal mines.

fewer "miners" than in the 1930's but production was more than twice as high. This same point was made graphically for the period $1936-56$ by Besford (1958: pl. 34), who also commented on the variation in the ratio of imports of NSW coal to Tasmanian coal production (ibid.: 139).

In 1858 , almost 2700 tonnes of Tasmanian coal was exported, whereas 129000 tonnes were imported (Booth 1962: appendix B), i.e. a ratio of 48:1 imports to exports. Besford (1958:139) in dealing briefly with the ratio of imported to local coal used, excluded gas and bunker coal on the basis that Tasmanian fields could not produce such coals. With exceptions for short periods only, Tasmanian coals have been used exclusively for steam raising or domestic uses.

\section{Uses of Tasmanian Coal}

The quality of Tasmanian coal has controlled the uses to which the coal has been put. The generally low content of volatile carbonaceous matter has usually precluded use in gas making. An exception to this is the Lower Permian coal which was used as a source of town gas for Latrobe (Cyclopaedia of Tasmania 2(1900): 239 and Dix (in Jennings 1979: 107)). The Dulverton and Russell Mines 


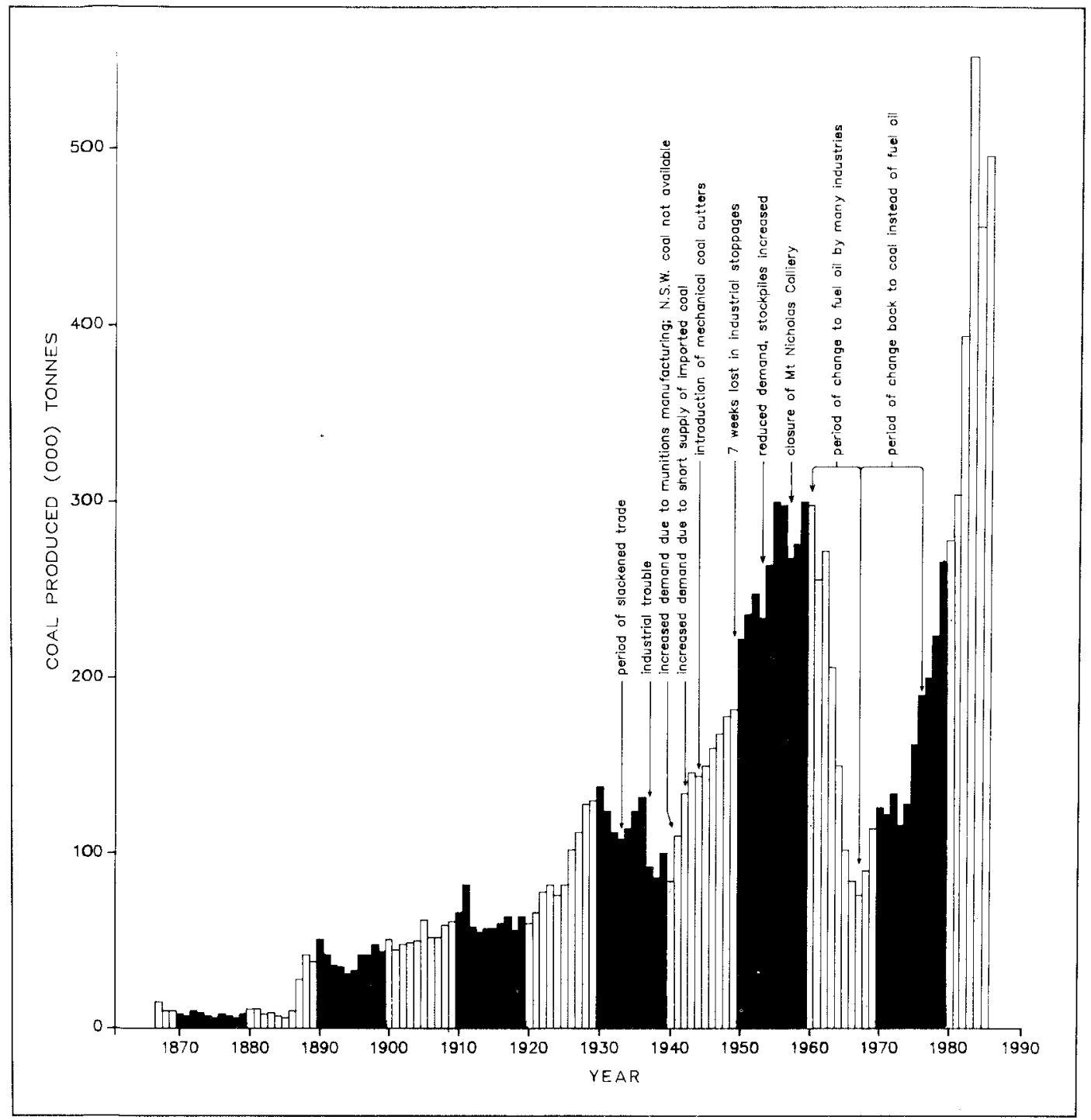

FIG 9 -- Production from Tasmanian coal mines from 1865-66 to present; from Department of Mines records.

provided the coal for this. The low content of VM and lack of coking properties has precluded widespread use of the coals for coking and smelting. Some Tasmanian coal was used in smelting in the 1870's (Booth 1962: introduction) but the quantity was small. Only minor quantities of Tasmanian coal have been used for bunkering of ships and there has been some use as locomotive fuel. For both uses the high ash content of the
Triassic coals is deleterious and the high sulphur content of the low-ash Lower Permian coals makes the Mersey coals unsuitable for use on the railways.

Last century most of the coal mined locally (and imported) was used as domestic fuel, with minor quantities of the local coal being used by the railways and steamships. During this century local industries, including hop kilns, used increasing amounts of local coal as boiler fuel for steam 


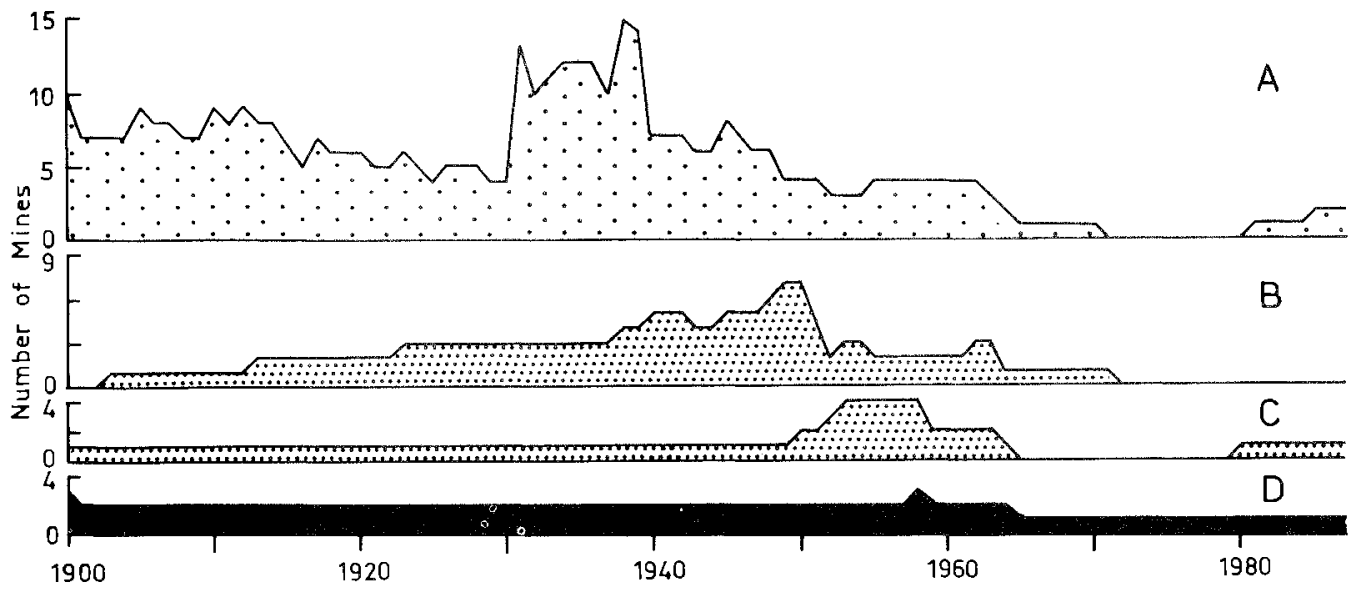

FIG 10 - Number of mines operating in Tasmania annually from 1900 to present, with analysis of size according to number of people directly employed; from Department of Mines records. (A) mines employing 1 to 5 people; $(B)$ mines employing 6-15 people; (C) mines employing 16-50 people; (D) mines employing more than 51 people.

raising or other heating purposes. The railways phased out steam engines in switching to diesel engines from the early 1950 's to early 1960 's but the drop in consumption by the railways was initially taken up by increased consumption by industry. Through the 1960's, many local industries which had been using coal in increasing quantities as a boiler fuel for steam-raising purposes converted to fuel oil, at the time a cheaper option than coal. One of the main industries using coal prior to this conversion was the paper-making industry (Besford 1958: pl. 33) and this situation continues. Tasmanian coal is now used in a wide variety of secondary industries.

\section{Mine Closures}

A summary of the reasons for mine closures is given in appendix 3 and table 4 . Early mining ventures were either thwarted by the geological difficulties or lacked sufficient capital to operate with maximum efficiency. A disaster, such as the loading jetty washing away, as happened at Adventure Bay, Seymour and Dalmayne, became a financial hurdle too large to be overcome and the operation closed.

At Catamaran, seven syndicates tried to work the field during the years 1900-40. The early syndicates spent most of their funds on massive infrastructure (which could be seen) such as bins, tramways, etc. and left insufficient funds for mine development proper. The same activity caused the failure of Swift's operation at Seymour and Dr Milligan's Douglas River mining ventures. In the last forty years the prime cause of mine closures has been the loss of markets, due to industry using fuel oil in preference to coal. Even when this trend reversed, the small mines did not re-open. With increased mechanisation and greater tonnages of coal per man produced now than in the days of hand-mining, the opening of a mine has become an expensive operation and can only really be justified on the larger deposits.

\section{TABLE 4}

Summary of Reasons For Closure of Tasmanian Coal Mines

\begin{tabular}{ccccc}
\hline & Geological & Mining & Economic & Fortuitous \\
\hline $1850-$ & 4 & - & 2 & 3 \\
1900 & $($ or 14$)$ & & & \\
$1901-20$ & - & 1 & 4 & 1 \\
$1921-40$ & 3 & 2 & $2+(?) 2$ & 1 \\
$1941-60$ & 9 & 1 & or $(?) 16$ & \\
$1961-80$ & 4 & $\frac{2}{6}$ & $\frac{3}{16+(?) 2}$ & $\frac{0}{6}$ \\
& $\frac{20}{\text { (or } 30)}$ & & or $(?) 16$ & 1 \\
\hline
\end{tabular}


One feaure of the closures has been the lack of attention to the geology of the coal area before mining began. The thickness and continuities of seams, the presence of faults and of dolerite have not been established prior to commencement of mining and sinking of large amounts of capital in infrastructure. Hills et al. (1922: 249-250) warned explicitly of the danger of such lack of attention.

It is significant that, after the rise in the price of oil in the early 1970's, the major thrusts in exploration with a view to almost immediate mine development were by large institutions. The Department of Mines mounted an intensive programme of geological and geophysical work and drilling in northeastern Tasmania from about 1974 to about 1981, with particular intensity from 1979 onward (Director of Mines Reports). Over this period two large companies were exploring in the northeast, one at each of Woodbury, Langloh and Catamaran in Upper Triassic fields and one in the Tertiary at Rosevale. These activities, with the possible exception of those at Woodbury, were in fields where coal had been discovered decades or more than a century ago.

\section{MINING METHODS}

The mining methods used in Tasmania are very largely the result of the geological and topographical conditions. Because the seams are almost horizontal (common dip up to $5^{\circ}$ ) and because the topography in most of the mining areas is rugged, the mine openings are commonly adits. Not infrequently the initial drive is up or down-dip. Water problems have been encountered where the drive is down-dip, e.g. Langloh, Dalmayne (Hills et al. 1922: 59). Mines in low-lying areas, e.g. Seymour (Hills et al. 1922: 61), Triabunna (ibid.: 107), Strathblane (ibid.: 151), Catamaran (ibid.: 163), New Town (ibid.: 173) and on the Mersey field (ibid:: 226-228), have been worked from shafts; in a few cases (e.g. Saltwater River) both adits and shafts were used.

Most of the coal mined in Tasmania has been won by the bord-and-pillar method, where parallel headings (bords) are driven and connections made between headings, so creating large blocks of coal (pillars) which are mined on retreat, a method which is often used to work a coal seam which is discontinuous on one horizon due to faulting.

On a number of occasions earlier this century the longwall method was used. This means the coal was mined across one long continuous face, with the roof collapsing behind the advancing face to form the goaf. For this arrangement a block of unfaulted coal is required, a condition not frequently met in most Tasmanian mines. A short or step longwall (where the coal face takes the shape of an irregular curve with blocks of coal left protruding as "steps") was used at the Cornwall Colliery until 1914 and at the Mt Nicholas Colliery in 1925 because of minor faulting. The longwall method was tried at Stanhope in 1943, but collapse of the longwall face in 1944 caused the management to revert to the more suitable bord-and-pillar method. Often miners were brought out from England especially to work in a particular mine, and probably the initial mine design and mode of working was based on their previous experience. Until the mines started to become mechanised (in 1943) mining was done by hand, with pit ponies pulling loaded coal skips to the surface on narrow gauge tram tracks. In 1943 an arc-wall coal cutting machine was installed at the Cornwall Colliery. The neighbouring mines soon also became mechanised, although some hand-mining continued into the 1950's.

The width of present headings (around $5 \mathrm{~m}$ ) is a legacy from the days of hand-mining, when headings were wide enough for a man to shovel at the side and throw coal into a skip in the middle of the heading (a distance of about seven feet $-2 \mathrm{~m}$ ). Today the shape of headings and pillars is much more regular than in the old hand-mining days. Fewer headings are required now than when there was a need to have a greater number of working places as there were more steps involved in the process of mining. Holes were bored in the face, charges laid, the face fired, the roof secured, the coal shovelled up. Commonly up to 16 or 20 headings were in use at the one time to provide the mining parties with sufficient working places. Pillars formed by hand-mining were smaller. Opencast mining has been used mainly at Merrywood and occasionally elsewhere, e.g. week-end workings near the old Cardiff Mine, the "Cardiff open-cut" and in front of the main portal at Blackwood West. In most places the overburdento-coal ratio is too high and the removal of overburden (largely dolerite) would be too expensive to allow this method to be used.

Transport of coal from mine mouth to railhead or jetty was frequently by wooden tramway but at the Cornwall and Mt Nicholas Collieries coal was moved by self-acting ground tramway from mine mouth to screens (Hills et al. 1922: 31). At Dalmayne a three-mile $(5 \mathrm{~km})$ aerial ropeway was used between the pit and the jetty (Hills et al. 1922: 53), and an aerial ropeway $3.6 \mathrm{~km}$ long was 
used at the Jubilee Colliery, taking coal from the pit top to a railway siding.

\section{CONDITIONS OF MINING}

The conditions in which the early miners worked were frequently difficult. Poor ventilation and not enough room to stand upright were common in many mines. The mining of thin seams, even less than two feet $(0.60 \mathrm{~m})$ thick in some cases, meant the miners had to work in very cramped conditions.

At Saltwater River convicts were intially employed in the underground mine and conditions were most unpleasant. The mine headings were only 1-2 $\mathrm{m}$ high and the ventilation was poor (Ford 1932, Burn 1892). A steam engine was installed in 1842 to raise the coal to the surface. Prior to this the coal was raised up shafts by a winch which used convict labour. Two pumps, which drew water from the workings, also used convict labour. Conditions at the coal mine were described by D. Burn after a visit to the mine in 1842 (see Burm 1892).

"Next morning I descended the main shaft along with Captain Booth; it is 52 yards [47.5 $\mathrm{m}]$ deep. The winch was manned by convicts under punishment. One stroke of the knife might sunder the rope, and then ... however it has never been tried, deeds of ferocity being very infrequent. A gang on the surface worked the main pump and another below worked a horizontal or slightly inclined draw pump which threw water into the chief well ... The seam has been excavated 100 yards $[90 \mathrm{~m}]$ from the shaft several chambers diverging left and right. The height of the bore is four feet [1.2 $\mathrm{m}]$. The quality of the coal partakes much more of anthracite than of bitumen, it flies a great deal but produces intense heat. The mines are esteemed the most irksome punishment the felon encounters because he labours night and day eight hours on a spell. Continuous stooping and close atmosphere caused our party to be bedewed with perspiration. I cannot therefore wonder at the abhorrence of the compulsory miner in loathing what I conceive to be a dreadful vocation ..."

The Reverend H.P. Fry visited the mine in 1848 and recorded that the shaft was $92.5 \mathrm{~m}$ deep, and that 400 convicts were employed at the mine site, although only 83 actually worked underground. Fry (1850) described the workings in detail: "...we groped our way with difficulty along passages which were said to be five miles [ 8 $\mathrm{km}$ ] in length. The roof in many places was so low that we were obliged to creep along the passage beneath it. The air was so confined that our lamps could with difficulty be kept burning and several of them went out. A few lamps at long intervals were attached to the walls, but seemed only like sparks glimmering in the mist, and not many yards from them the passage was in perfect darkness. There were 83 men at work in the mines when I visited them, the greater number employed in wheeling the coal to the shaft to be hoisted up. They worked without any other clothing than their trousers and perspired profusely. The men in the mine were under the charge of a prisoner-overseer and a prisoner constable."

To be sent to work at the coal mine was regarded as a punishment by the convicts at Port Arthur, although the work at the mines was no more severe than at Port Arthur and the rations were the same (Besford 1957). The punishment rate was, however, high. Hartwell (1954) notes that for the year 1847 , 1400 punishments were meted out to the 400 workers. These included 728 sentences of solitary confinement with bread and water, given out by the Superintendent, while the Magistrate imposed 672 punishments of flogging, sentencing to chains, or periods of solitary confinmement.

An Examiner published in April 1871, carried a graphic account of the "Don Coal Mines". The adit was only four feet $(1.2 \mathrm{~m})$ square and followed the dip of a seam only 0.2 to $0.46 \mathrm{~m}$ thick. Drives had been cut along the seam at right angles to the adit and from the drives excavations were made on either side. The miners worked in "recumbent, kneeling or squatting positions." The description is that of a mine working a thin seam by the bordand-pillar method and with minimum expenditure.

More recently opened mines have more headroom (the seams are thicker in the Triassic coal measures) and mining conditions are more comfortable.

\section{OVERVIEW}

The coal-mining industry in Tasmania has not been a major industry but has provided employment directly for up to just over 400 people at a time. It has not been a bigger industry partly for geological reasons. Most of the seams are too thin and the coal 
itself is not of high enough quality for export in the face of competition from mines in NSW and Queensland. Gas-making coals are present and have been used as such a little, but the seams of Permian coals with enough vitrinite and or/liptinite to provide gas are thin and very faulted. The Triassic coals, without exception, are inertinite-rich and thus not suitable for gas or coke making; further, they have high ash contents (modally about $20 \%$ ) and relatively low (modally about $26 \mathrm{mj}$ ) specific energies. As noted earlier they have been predominantly used for heating or steam raising.

Despite the difficulties noted above in using Tasmanian coals, and although most mining operations have been short-lived and on a small scale, coal mining has played an important role in the history of at least two communities, that of the Mersey Valley in the 1850's and that of the South Esk Valley after about 1890 .

Although settlement had already occurred on the Mersey at Frogmore and elsewhere prior to 1850 (Ramsay 1958), the discovery of coal there and subsequent commencement of mining attracted entrepreneurs, capital and miners to the area (Ramsay 1958: 118-126). Tarleton became "a large town" in the 1850 's but by 1870 only one family remained, although there were others at Ballahoo and Sherwood (Ramsay 1958: 127-128). Ramsay (op. cit.: 128) noted that "the finding of coal set off the real development of the Mersey estuary", but after the first decade or two other industries replaced coal in importance.

The importance of coal mining to the towns of Avoca, Fingal and St Marys in the South Esk Valley became obvious when Tasmanian companies began to switch from coal-burning to oil-burning furnaces in the 1950's. Dalmayne stopped producing in the early 1950 's; five mines - Mt Nicholas, Mt Christie No. 1, Stanhope, Tasmania and Jubilee stopped producing in the three years beginning 1956 and then a further six stopped in the three years from 1963 (Merrywood, Tasmania [after a reopening], Mt Christie No. 2, Cornwall, The Valley and the Fingal). In all, 14 mines in this one area stopped work in the 18 years beginning 1951 . It was reported in 1961 (Mercury 20 April) that more than half the 3500 inhabitants of the valley depended directly on coal mining and half of the rest depended on coal for trade and wages. Private and company houses were up for sale but attracted no buyers. The Mercury of 15 April 1961 reported that almost sixty miners had lost their jobs over the last two years and over thirty were on forced longservice leave. Within a few months in 1965 (February to April; Mercury 17 February, 7 April) it seems that over forty miners lost their jobs out of a mining force of just over 100. Offical figures on employment in the coal-mining industry (Director of Mines Reports for the years 1960 to 1966 inclusive) reveal a loss of 241 jobs in the industry of a total of 307 at the beginning of the period (i.e. $78.5 \%$ over seven years or an average of about $11 \%$ per annum), with the highest annual loss of $35.2 \%$ in 1965 . These figures cover the whole industry but few mines were operating outside the Fingal Valley. Many of the miners dismissed were found work with the Forestry Commission working in plantations in the area but the social and economic effects of the closures were severe.

\section{ACKNOWLEDGEMENTS}

During compilation of this paper, we have received help particularly from Mrs M.R. Banks, from the staff of the State Archives, especially Mr Jeff Stilwell, from Mrs Faye Gardam of Port Sorell, Mr Roger Kellaway of the Department of Geography and Professor Michael Roe, of the Department of History, University of Tasmania, Mr Michael Dix, Mr Ken Bird and Mr Geoff Thomas, Department of Mines. Miss Pat Ross helped by tracing archival material. To all of these people we extend our thanks. Carol Bacon publishes with the permission of the Director of Mines, Tasmania.

\section{REFERENCES}

Alexander A., 1986: GLENORCHY, 1804-1964. Glenorchy City Council, Glenorchy, Tasmania.

Bacon. C.A., 1986a: Brown coal deposits in Tasmania. Unpubl. Rep. Dep. Mines Tasm. 1986/19.

BACON, C.A., 1986b: Coal in Tasmania. Unpubl. Rep. Dep. Mines Tasm. 1986/43.

Bacon, C.A. \& Calver, C.R., 1986: Petrography and palaeoenvironments of some Permian coals, Nicholas Range, north-eastern Tasmania. Unpubl. Rep. Dep. Mines Tasm. 1986/34.

BACON, C.A. \& Everard, J.L., 1981: Triassic rhyolitic ash-fall near Bicheno, Tasmania. Search 12(6): 177-8.

Banks, M.R., 1962: Permian. In Spry, A.H. and Banks, M.R.(Eds): THE GEOLOGY OF TASMANIA. J. Geol. Soc. Aust. 9(2): 189-215.

Banks, M.R., 1971: A Darwin manuscript on Hobart Town. Pap. Proc. R. Soc. Tasm. 105: 5-19.

BANKS, M.R., 1978: Correlation chart for the Triassic System of Australia. Bur. Miner. Resour. Geol. \& Geophys. Bull. 156C.

BARLOW, N., 1933: CHARLES DARWIN'S DIARY OF THE VOYAGE OF H.M.S. BEAGLE. Cambridge University Press. 
Besford, D., 1958: Coal in Tasmania. Tech. Rep. Dep. Mines Tasm. 2: 127-143.

BIGGE, J.T., 1822: REPORT OF THE COMMISSIONER OF INQUIRY INTO THE STATE OF THE COLONY OF NEW SOUTH WALES. London.

Blainey. G., 1954: Population movements in Tasmania, 1870-1901. Tasm. Hist. Res. Assoc. Pap. Proc. 3(4): $62-70$.

Blainey, G., 1961: Gold and governors. Hist. Stud. Aust. N.Z. $9(36): 337-50$

Blake, F., 1938: Rooks River Tinfield-Cape Barren Island. Unpubl. Rep. Dep. Mines Tasm. 30-32.

BlaKe, F., 1940: Brown coal and lignite in Tasmania. Unpubl. Rep. Dep. Mines Tasm. 1940: 42-43.

Booth, B., 1962: Ninety years of the Tasmanian coal industry. Unpubl. Hons thesis, Univ. Tasm.

Brand, I., in press: PENAL COAL. Jason Publications, Hobart.

Brongniart, A., 1807: TRAITÉ ÉLEMENTAIRE DE MINÉRALOGIE. Tome 2.

BURN, D., 1892: AN EXCURSION TO PORT ARTHUR IN I842. Facsimile reprint 1972, H.A. Evans \& Son, Melbourne.

Burns, K.L., 1963: Deep drilling near Latrobe. Tech. Rep. Dep. Mines Tasm. 7: 29-36.

Burns, K.L., 1964: Devonport. Geological Atlas I mile ser, Explan Rep. K/55-6-29. Tasm. Dep. Mines.

Calver, C.R., Clarke, M.J. \& Truswell, E.M., 1984: The stratigraphy of the Late Palaeozoic borehole section at Douglas River, eastern Tasmania: a synthesis of marine macro-invertebrate and palynological data. Pap. Proc. R. Soc. Tasm. 118: 137-161.

Cantrill, T.C., 1914: COAL MINING. Cambridge University Press, London.

CAREY, S.W., 1946: Report on peat, lignite and brown coal deposits on King Island. Unpubl. Rep. Dep. Mines Tasm. 1946: 6-29.

Clarke, W.B., 1878: Remarks on the sedimentary formations of New South Wales. Government Printer, Sydney.

Cookson, I.C., 1953: The identification of the Sporomorph Phyllocladidites with Dacrydium and its distribution in southern Tertiary deposits. Aust. J. Bot. 1: 474 .

Cookson, 1.C., 1954a: Some Dicotyledonous pollen types from Cainozoic deposits in the Australian Region. Aust. J. Bot. 2: 197-219.

Cookson, I.C., 1954b: The Cainozoic occurrence of Acacia in Australia. Aust. J. Bot. 2: 52.

Cookson, I.C., 1956: Pollen grains of the Ephedra type in Australian Tertiary deposits. Nature 177: 47.

Cookson, I.C., 1957: On some Australian Tertiary spores and pollen grains that extend the geological and geographical distribution of living genera. Proc. $R$ Soc. Vict. 69: 41-53.

Cookson, I.C., 1967: Some Early Tertiary microplankton and pollen grains from a deposit near Strahan, western Tasmania. Proc. R. Soc. Vict. 80(1): 131-140.

Cookson, I.C. \& Duigan, S., 1951: Tertiary Araucariaceae from South-Eastern Australia with note on living species. Aust. J. Sci. B4: 415-449.
Cookson, 1.C. \& PIKe, K., 1953: A contribution to the Tertiary occurrence of the genus Dacrydium in the Australian Region. Aust. J. Bot. 1: 474

Crapp, C.E. \& Nolan, R.C., 1975: Newcastle district. In Traves, D.M. \& King, D.(Eds): ECONOMIC GEOLOGY OF AUSTRALIA AND PAPUA NEW GUINEA. 2 - COAL. A.I.M.M. Monograph Series 6 , Parkville, Victoria: 163-175

Daintree, R., 1872: Notes on the geology of Queensland. Q. J. Geol. Soc. Lond. 28: 271-317.

DE LA Beche, H.T., 1851: Analysis of coal from Van Diemens Land with Report. Pap. Proc. R. Soc. V.D.L. I: $265-266$.

DeNISON, W., 1870: VARIETIES OF VICE REGAL LIFE. Longman Green and Co., London.

Dettman, M., 1961: Lower Mesozoic megaspores from Tasmania and South Australia. Micropaleontology 7 : $71-86$.

Dickinson, D.R., 1945: Ben Lomond Coal. Unpubl. Rep. Dep. Mines Tasm.: 12-13.

Dulhunty, J.A. \& Dulhunty, R., 1949: Notes on microspore types in Tasmanian Permian Coals. Proc. Linn. Soc. N.S.W. 74(3-4): 132-139.

DunN, E.J., 1910: Biographical sketch of the founders of the Geological Survey of Victoria. Bull. Geol. Surv. Vict. 23.

Elford, H.S. \& McKeown, M.R., 1947: COAL MINING IN AUSTRALIA. Tait, Melbourne.

Fenton, J., 1891: BUSH LIFE IN TASMANIA FIFTY YEARS AGO. Hazell, Watson \& Viney, London and Aylesbury.

FORD, T.G., 1932: INHUMANITY. HISTORICAL TALES OF OLD CONVICT DAYS ... AND OTHER STORIES BY THE CAPTAIN. J. Walch, Hobart.

FORSYTH, S.M., 1984: Oatlands. Geological Atlas I:50,000 ser. Explan. Rep. Sheet 68 (8313S). Tasm. Dep. Mines.

FRY, H.P., 1850: A SYSTEM OF PENAL DISCIPLINE WITH A REPORT ON THE TREATMENT OF PRISONERS IN GREAT BRITAIN AND IN VAN DIEMENS LAND. Longman, Green and Longman, London.

GILL, E.D. \& Banks, M.R., 1956: Cainozoic history of the Mowbray Swamp and other areas of north-western Tasmania. Rec. Q. Vict. Mus. 6: 1-41.

Gould, C., 1861a: Coalfields (Fingal and East Coast). Report of Government Geologist. House of Assembly Pap. Tasm. 1861(9).

Gould, C., 1861b: Mersey Coalfield. House of Assembly Pap. Tasm. 1861(9).

Gould, C., 1861c: Report on ascertaining the commercial value of coal. House of Assembly J. Tasm. 65.

Gould, C., 1865: Notes on the geological structure of the north-east coast of Tasmania. Pap. Proc. R. Soc. Tasm. 63-66.

Gould, C., 1869: Coal south of Oatlands. House of Assembly Pap. Tasm. 1869(18).

Hale, G.E.A., 1962: Triassic System. In Spry, A.H. \& Banks, M.R. (Eds): THE GEOLOGY OF TASMANIA J. Geol. Soc. Aust. 9(2): 217-231. 
Harris, V.K., 1968: Tasmanian Tertiary and Quaternary microfloras. Summary Report. Dep. of Mines S. Aust. Pal, Rej. 5/68.

HARTWELI R.M., 1954: ECONOMIC DEVELOPMENT OF VAI DIEMENS LAND, 1820-1850. Melbourne University Press, Melbourne.

HEARD, D., 1981: THE JOURNAL OF CHARLES O'HARA BOOTH. Tasmanian Historical Research Associalion, Hobart.

H.E.C. (Hydro-Electric Commission), 1967 : Tasmanian coal resources investigation, Fingal area geological report. H.E.C., Hobart.

Hills, L., Rerd, A.M., Nye, P.B., Keid, H.G.W. \& Reid, W.D., 1922: The Coal Resources of Tasmania. Geol. Surv. Tasm. Miner. Resour. 7.

Новвs, J, 1824: Boat expeditions around Tasmania, 1815-1816 and 1824. House of Assembly Pap. Tasm. 1881. (Reprinted 1986): THE LOG. Government Printer, Hobart.

Hoddinot?, W.G., 1967: Joseph Milligan (1807-1884). In Pike D., (Ed.): AUSTRALIAN DICTIONARY OF BIOGRAPHY. Vol. 2. Melbourne University Press, Melboune: 230-231.

Horne, T, 1864: Report of the Select Committee on Coalfields, 1864. House of Assembly Pap. Tasm. 1864 (95).

Hughes, T.D., 1952: Coal near Mt Lloyd. Unpubl. Rep. Dep. Mines Tasm. 1952: 17-19

Hughes, T.D., 1955: Notes on coal prospects near Dover. Unpubl. Rep. Dep. Mines Tasm. 1955: 30-31.

Hughes, T.D., 1960: Thermal springs, Hastings. Tech. Rep. Dep. Mines Tasm. 5: 44-46.

Hughes, T.D., 1962: Coal at West Takone. Tech. Rep. Dep. Mines Tasm. 6: 55-57.

Hughes, T.D. \& Burns, K.L., 1961: Notes on the geology of the proposed factory site for A.P.P.M. at Wesley Vale. Tech. Rep. Dep. Mines Tasm. 5: 198-203.

Hunt, J.W., 1987: Sulphur in the Permian coals of eastern Australia: variation and geological control. Aust. Coal Geol. 7: 11-32.

JAMESON, R., 1808: ELEMENTS OF GEOGNOSY. VOL. 3. SYSTEM OF MINERALOGY. Blackwood, Edinburgh

Jennings, I.B., 1979: Sheffield. Geological atlas $l$ mile ser. Explan. Rep. Sheet 37 (8115S). Tasm. Dep. Mines.

Johnstron, R.M., 1873: Regarding the composition and extent of certain Tertiary beds in an around Launceston. Pap. Proc. R. Soc. Tasm.: 39-47.

Johnston, R.M., 1875: The Launceston Tertiary basin second paper. Pap. Proc. R. Soc. Tasm.(1874): 53-62.

Johnston, R.M., 1887: Fresh contributions to our knowledge of the plants of Mesozoic age in Tasmania. Pap. Proc. R. Soc. Tasm. (1886): 160-182.

JoHnston, R.M., 1888: A SYSTEMATIC ACCOUNT OF THE GEOLOGY OF TASMANIA. Government Printer, Hobart.

Johnston, R.M., 1892: Notes on a collection of plant impressions from the Henty River. Pap. Proc. $R$. Soc. Tasm. (1891): 11-13.
Johnston, R.M., 1894: Further contributions to the fossi flora of Tasmania. Part 1. Pap. Proc. R. Soc. Tasm. (1893): $170-178$.

Johnston, R.M., 1901: Progress of Tasmania 1816 to 1900. Tasm. Secy Mines Rep. (1900-01).

JulEN, H., 1976: THE PENAL SETTLEMENT OF MACQUARIE HARBOUR 1822-1833: AN OUTLINE OF ITS HISTORY. Mary Fisher Bookshop, Launceston.

KeId, H.G.W., 1952: The Strathblane, Ida Bay and Catamaran Coalfields. Unpubl, Rep. Dep. Mines. Tasm.: 25-29.

Krause, F., 1884: Report on the New Town coal deposits. House of Assembly Pap. Tasm. 1884(59).

LABILlaRdIERE, J.-J.H. DE, 1800: VOYAGE IN SEARCH OF LA PÉROUSE DURING THE YEARS 1791-1794. Stockdale, London.

Lewis, A.N. \& Volsey, A., 1938: A record of volcanic activity in Tasmania during Triassic times. Pap. Proc. R. Soc. Tasm. (1937): 31-39.

L'Huillier, L., 1969: Depression and a national economy. In Griffin, J.(Ed.): ESSAYS IN ECONOMIC HISTORY OF AUSTRALIA. Jacaranda Press, Brisbane: 186-206

Macculloch, J., 1831: A SYSTEM OF GEOLOGY WITH A THEORY OF THE EARTH. Longman, London.

Mackaness, G.(Ed.), 1947: SOME PRIVATE CORRESPONDENCE OF SIR JOHN AND LADY JANE FRANKLIN (TASMANIA, I837-I845). Ford, Dubbo, N.S.W.

MaUde, A.M., 1965: Discovery and exploration. In Davies, J.L.(Ed.): ATLAS OF TASMANIA. Lands and Surveys Dep., Hobart: 38-39.

MCGHEE, R., 1969: The long boom, 1860-1890. In Griffin, J.(Ed.): ESSAYS IN ECONOMIC HISTORY OF AUSTRALIA. Jacaranda Press, Brisbane: 135-185.

MCKAY, A., 1962: JOURNALS OF THE LAND COMMISSIONERS FOR VAN DIEMENS LAND 1826-1828. Univ. Tasm.-Tas.Hist.Res. Assoc.

M'Cor, F., 1847: On the fossil botany and zoology of the rocks associated with the coal of Australia. Ann. Mag. Nat. Hist. 20: 145-7, 226-236, 298-312.

M'Coy, F., 1848: On the plants of the New South Wales and Van Diemens Land Coal fields. B.A.A.S. Rep. (1847): 64-65.

MCNEIL, R.D., 1961: Geological reconnaissance of the Arthur River area. Tech. Rep. Dep. Mines Tasm. 5: 46-60

Milligan, J., 1849: Reports on the coal basins of Van Diemens Land. Pap. Proc. R. Soc. V.D.L. I:1-82; read Aug. 1848 to Feb. 1849.

Milligan, J., 1852: Report on the coal said to have been found at the Don River, and upon the west bank of the Tamar River in Tasmania. Pap. Proc. R. Soc. Tasm. 2: 90-106; read July 1851 .

Montgomery, A., 1891: Report on the proposal to bore for coal in the township of Triabunna, Spring Bay, and its neighbourhood. Tasm. Secy Mines Rep. 1890-1891: $15-22$.

Montgomery, A, 1892: Report on the Ben Lomond district. Tasm. Secy Mines Rep. 1891-2: 25-40. 
Montgomery, A., 1893: Report on the country between Mole Creek and the Mt Dundas Silver Field and on the discovery of coal at Barn Bluff. Tasm. Secy Mines Rep. 1892-3.

Montgomery, A., 1894: Report on the Lawrenny Langloh Coalfield. Tasm. Secy Mines Rep. 1893-4: xli-l.

Montgomery, A, 1896: Report on the mineral fields of the Gawler River, Penguin, Dial Range, Mount Housetop, Table Cape, Cam River and portion of the Arthur River district. Tasm. Secy Mines Rep. 1895-6: $\mathrm{i}-\mathrm{XX}$.

Morrison, K.C. \& BAcon, C.A., 1986: Comparison between the Fingal and Langloh Coalfields, Tasmania Basin. Coal Geol. 6: 41-57.

Murray, C.G., 1983: Permian geology of Queensland. Keynote address. In PERMIAN GEOLOGY OF QUEENSLAND. Geol. Soc. Aust. Q1d Div., Brisbane: $1-32$.

Nye, P.B., 1923: The silver-lead deposits of the Waratah district. Bull. Geol. Surv. Tasm. 33.

NyE, P.B., 1928: Report on the borehole at Northdown. Unpubl. Rep. Dep. Mines Tasm.

NyE, P.B., 1929: Departmental report on coal at Harland Rise, Evandale. Unpubl. Rep. Dep. Mines Tasm. 1929: 24.

Nye, P.B. \& Blake, F., 1938: Geology and Mineral Deposits of Tasmania. Bull. Geol. Surv. Tasm. 44.

Nye, P.B., Finucane, K.J. \& Blake, F., 1934: The Smithton district. Bull. Geol. Surv. Tasm. 41.

Playford, G., 1965: Plant microfossils from Triassic sediments near Poatina, Tasmania. J. Geol. Soc. Aust. 12(1): 173-210.

Plomley, N.J.B., 1971: Friendly Mission: The Tasmanian Journals and Papers of G.A. Robinson 1829-1834, a supplement. Tasm. Hist. Res. Assoc. Pap. Proc. 18(1): 7-32.

Pretyman, E.R., 1967: Kelly, James (1791-1859). In Pike, D. (Ed.): AUSTRALIAN DICTIONARY OF BIOGRAPHY 2: 36-37.

RaMSAY, C., 1958: WITH THE PIONEERS. Mercury, Hobart.

Reid, A.M., 1919: The Mount Pelion Mineral Deposit. Bull. Geol. Surv. Tasm. 30.

Re1D, A.M., 1924: The oil shale resources of Tasmania. Miner. Resour. Tasm. 8(1).

Rude, G., 1967: Zephaniah Williams. In Pike, D. (Ed.): AUSTRALIAN DICTIONARY OF BIOGRAPHY 2: 601-602.

ScotT, P., 1965: Land settlement. In Davies, J.L. (Ed.): ATLAS OF TASMANIA. Lands and Surveys Dep., Hobart: $43-45$.

ScotT, T.H., 1824: Sketch on the geology of New South Wales and Van Diemens Land. Ann. Philos. June 24: $461-462$.

SELWyn, A.R.C., 1855: Report on the geological relations of some of the coal seams of Van Diemens Land, their probable extent and relative economic value. Pap. Proc. R. Soc. V.D.L. III(1): 116-141.

SHAw, A.G.L. \& BRUNS, G.R., 1947: THE AUSTRALIAN COAL INDUSTRY. Melbourne University Press.
Smyth, M., 1979: Petrology of the Duncan Seam from Duncan Mine, Fingal, Tasmania. CSIRO Fuel Science Unit Rep.

Smyth, M., 1980: Coal encounters of the third kind: Triassic. Coal Geol. 2(3-4): $161-178$

SPROD, T.D., 1977: ALEXANDER PEARCE OF MACQUARIE HARBOUR. CONVICT-BUSHRANGERCANNIBAL. Cat and Fiddle Press, Hobart.

Strachey, J., 1719: A curious description of the strata observed in the coal-mines of Mendip in Somersetshire: Phil. Trans. R. Soc. 30, 968-973.

STRzeleCK1, P.E. voN, 1842: On certain varieties of Australian coal. Tasm. J. Nat. Sci. 1(3): 190-203.

STRZELECKI, P.E. von, 1845: PHYSICAL DESCRIPTION OF NEW SOUTH WALES AND VAN DIEMENS LAND. Longman, Brown, Green and Longmans, London.

Tasmanian Year Book No. 9: 1975. ABS Tasm. Office, Government Printer, Hobart.

Threader, V.M., 1972: Diamond drilling at the Sandfly Coal Mine, Kaoota. Tech. Rep. Dep. Mines Tasm. 15: $40-43$.

Thureau, G., 1881a: Report on the southern coal measures at Sandfly, Parish of Longley, County of Buckingham. House of Assembly Pap. Tasm. 1881(109): 12-14.

Thureau, G., 1881b: Report on the coal mines in the vicinity of Gardner's and Randall's Bays. House of Assembly Pap. Tasm. 1881(109).

Thureau, G., 1883c: The Carboniferous deposits near New Town. House of Assembly Pap. Tasm. 1883(3).

Townrow, J.A., 1962: Palaeontology; Depositional Environments. In Spry, A.H. \& Banks, M.R. (Eds): THE GEOLOGY OF TASMANIA. J. Geol. Soc. Aust. 9(2): $224-225,230$.

Townrow, J.A., 1964: A speculation on the RhaetoLiassic climate of Tasmania. Pap. Proc. R. Soc. Tasm. 98: 113-118.

Truswell, E.M., 1978: Palynology of the PermoCarboniferous in Tasmania, and interim report. Bull. Geol. Surv. Tasm. 56.

Twelvetrees, W.H., 1901: Report on the mineral districts of Zeehan and neighbourhood. Eden Coal Mine. Tasm. Secy Mines Rep. (1900-01): 105-106.

Twelvetrees, W.H., 1902a: Outlines of the geology of Tasmania. Pap. Proc. R. Soc. Tasm. (1900-01): 58-74.

Twelvetrees, W.H., 1902b: Report on country on the east shore of Lake Sorell, and on a discovery of coal near Oatlands. Tasm. Secy Mines Rep. 1901-02: 159-169.

Twelvetrees, W.H., 1902c: Report on the occurrence of coal near Catamaran River, Recherche Bay. Tasm. Secy. Mines Rep. 1901-02: 132-138.

Twelvetrees, W.H., 1903: Report on kerosene shale and coal seams in the Parish of Preolenna. Tasm. Dep. Mines Rep., Old Series 206.

Twelvetrees, W.H., 1904: Report on coal near George Town and slate near Badger Head. Tasm. Dep. Mines Rep., Old Series 228.

Twelvetrees, W.H., 1906: On coal at Mt Rex. Tasm. Secy. Mines Rep. 1905: 1-8. 
Twelv ETReES, W.H., 1911: The tasmanite shale fields of the Mersey District. Bull. Geol. Surv. Tasm. 11.

Twelverrees, W.H., 1915: The Catamaran and Strathblane coal fields, and coal and limestone at Ida Bay (southern Tasmania). Bull. Geol. Surv. Tasm. 20.

VALLANCE, T.G., 1981: The fuss about coal-troubled relations between palaeobotany and geology. In Carr, D.J. and Carr, S.G.M. (Eds): PLANTS AND MAN IN AUSTRALIA. Academic Press, Sydney: 136-176.

WALKOM, A.B., 1925: Notes on some Tasmanian Mesozoic Plants. Part I. Pap. Proc. R. Soc. Tasm. (1924): 73-89.

Walkom, A.B., 1926: Notes on some Tasmanian Mesozoic Plants. Part II. Pap. Proc. R. Soc. Tasm. (1925): 63-74.

WALLER, G.A., 1902: Report on the recent discovery of cannel coal in the Parish of Preolenna, and upon the New Victory Copper Mine near the Arthur River. Tasm. Secy Mines Rep. 1901-02: 77-90.

WARD, C.R., 1984: COAL GEOLOGY AND TECHNOLOGY. Blackwell Scientific, Melbourne.

Whith AM, L.S., 1973: The Sandfly coal mine and tramway. Tasm. Hist. Res. Assoc. Pap. Proc. 20: 201-209.

Whitham, L.S., 1983: The Catamaran colliery and its transport systems. Tasm. Hist. Res. Assoc. Pap. Proc. 30(2): 69-81.

WILSON, R.G., 1975: Southern Coal-field. In Traves, D.M. \& King, D. (Eds): ECONOMIC GEOLOGY OF AUSTRALIA AND PAPUA NEW GUINEA - 2. COAL. A.I.M.M. Monograph Series 6, Parkville, Victoria: 206-2I8.

WINCH, N.J., 1823: An account of some specimens of rocks etc. from Van Diemens Land and N.S.W. Thomson's Annals Phil. n.s. V: 341-342.
ZitTEL, K.A. von, 1901: HISTORY OF GEOLOGY AND PALAEONTOLOGY TO THE END OF THE NINETEENTH CENTURY. Walter Scott, London.

\section{ABBREVIATIONS USED FOR CITATIONS IN TEXT}

Records Held in Tasmanian State Archives

CGF - Comptroller General's File.

CON - Convict files, State Archives.

CSD - Records of Chief Secretary's Departinent.

CSO - Records of Colonial Secretary's Office.

GO - Governor's Office records.

HRA - Historical Records of Australia.

HRNSW - Historical Records of New South Wales.

LSD - Records of Lands and Surveys Department.

\section{Other}

DoM - Department of Mines

HAJ - House of Assembly Journals

TSA - Tasmanian State Archives

VDL - Van Diemens Land

(accepted 12 May 1989) 


\section{APPENDIX 1}

\section{Discoveries and Discoverers of Coal in Tasmania}

In preparing this appendix an attempt has been made to determine as closely as possible the date of discovery. In very few cases can dates be quoted. In more cases a year, with or without month, can be determined. Much more commonly it has been possible only to quote the date of the earliest public record of a discovery. In such cases the year of the record is preceded by a "<"; thus " $<1833$ " indicates that the discovery was made in or prior to 1833 . In a few cases the site of a discovery can be determined accurately from old maps and the sites identified on modern, detailed maps. Such sites are given the appropriate grid co- ordinates e.g. DM970908, as determined from the Tasmanian 1:100 000 topographic maps. All points in Tasmania lie in Universal Grid Zone 55G. In some cases sites of discovery can only be approximated: in such cases the co-ordinates are bracketed. The geological position of the coal discovered is indicated by the letters "LP" (Lower Permian), "UP" (Upper Permian), "UTr" (Upper Triassic) and "L" for lignite of Tertiary age, the older coals being black coals. Not all discovery sites are listed by number; thus only the first discovery within the one geological structure is numbered. Even so, there are many discoveries listed because the coal measures are much broken by faulting and dolerite intrusion. Wherever possible the name (and occupation) of the discoverer(s) are noted and a reference given to the first public record of the discovery. * following the name of the discoverer indicates a reward lease granted; $\dagger$ a reward lease applied for, not granted.

\begin{tabular}{|c|c|c|c|c|c|}
\hline Item & Date & Locality & Age & Discoverer & Reference \\
\hline 1 & 15.2 .1793 & $\begin{array}{l}\text { South Cape Bay } \\
\text { DM } 850730\end{array}$ & $\mathrm{Tr}$ & $\begin{array}{l}\text { J-J.H. de Labillardière } \\
\text { (Explorer) }\end{array}$ & Labillardière $1800,2: 22$ \\
\hline 2 & 8.11 .1803 & $\begin{array}{l}\text { Coal River, Richmond } \\
\text { EN36656790 }\end{array}$ & $\mathrm{Tr}$ & $\begin{array}{l}\text { James Meehan } \\
\text { (Surveyor) }\end{array}$ & TSA Map, Monmouth PIan 0 \\
\hline 3 & 1804 & $\begin{array}{l}\text { Tamar River, western shore } \\
2 \text { miles ( } 3 \mathrm{~km} \text { ), above Middle } \\
\text { Island just north of Blackwood } \\
\text { Hills (DQ909438) }\end{array}$ & $\mathbf{L}$ & Anon. & $\begin{array}{l}\text { Paterson HRNSW V: } 500 \\
\text { ("bituminous earth") }\end{array}$ \\
\hline 4 & 1809 & Schouten Island (FP030160) & $\operatorname{Tr}$ & $\begin{array}{l}\text { James Stacey } \\
\text { (Sailor, shipwrecked) }\end{array}$ & GO 39/4: 29 \\
\hline 5 & $\begin{array}{l}\text { ?1813 } \\
\text { (certainly } \\
\text { pre-1823) }\end{array}$ & $\begin{array}{l}\text { Jerusalem (Colebrook) } \\
\text { (EP294945) }\end{array}$ & $\mathrm{Tr}$ & Anon. & $\begin{array}{l}\text { Map engraved by Chas } \\
\text { Thompson, Edinburgh, from } \\
\text { survey by Capt. Dixon, } \\
\text { Skelton of Whitby. Dixon } \\
\text { was in Hobart in } 1823 \\
\text { (Besford 1958). }\end{array}$ \\
\hline 6 & 1815 & $\begin{array}{l}\text { Macquarie Harbour } \\
\text { (Coal Head) (CP705140) }\end{array}$ & $\mathbf{L}$ & $\begin{array}{l}\text { Capt. James Kelly } \\
\text { (mariner and exporer) }\end{array}$ & $\begin{array}{l}\text { Hobart Town Gazette } \\
15 \text { June } 1876\end{array}$ \\
\hline 7 & $<6.3 .1820$ & Adventure Bay EN261018 & UP & Thomas Kent (tanner) & HRA III(3): 257 \\
\hline 8 & $<1823$ & New Town (EN245545) & $\mathrm{Tr}$ & Anon. & $\begin{array}{l}\text { Winch } 1823 \text { (based on } \\
\text { specimens sent by J. Scott) }\end{array}$ \\
\hline 9 & 1824 & $\begin{array}{l}\text { Huon Inlet (?Coal Mine Bay } \\
\text { — now Sandrock Bay) } \\
\text { (EN079126) }\end{array}$ & $\mathrm{UP}$ & Thomas Scott & $\begin{array}{l}\text { Leg. Counc. J. 6, pap.16, } \\
1861\end{array}$ \\
\hline 10 & $<1831$ & New Norfolk & ?Tr & Anon. & Ross's Almanack 1831: 30 \\
\hline 11 & $<1831$ & $\begin{array}{l}\text { Jericho (?Sag Hill) } \\
\text { (EN039974) }\end{array}$ & $\operatorname{Tr}$ & Anon. & Ross's Almanack 1831: 30 \\
\hline & $<1831$ & \multicolumn{3}{|c|}{ Satellite Island — incorrect - there is no coal on this island } & Ross's Almanack 1831: 30 \\
\hline
\end{tabular}




\begin{tabular}{|c|c|c|c|c|c|}
\hline Item & Date & Locality & Age & Discoverer & Reference \\
\hline 12 & 1832 & $\begin{array}{l}\text { Near Hampshire (? West } \\
\text { Takone CQ7 } 18412 \text {, } \\
\text { ?Preolenna } \sim \text { CQ760440) }\end{array}$ & LP & $\begin{array}{l}\text { Joseph Milligan } \\
\text { (surgeon and part-time } \\
\text { geologist) }\end{array}$ & VDL Co. Ann. Rep. 1832 \\
\hline 13 & $<$ May 1833 & $\begin{array}{l}\text { Plunkett Point } \\
\text { EN586402 }\end{array}$ & $\mathrm{Tr}$ & $\begin{array}{l}\text { George Woodward \& } \\
\text { James Hughes } \\
\text { (surveyors) }\end{array}$ & $\begin{array}{l}\text { CSO 1/680/15052; GO33/16, } \\
\text { 265-5; O'Hara Booth J. 23 May } \\
1833 \text { (Heard 1981) }\end{array}$ \\
\hline 14 & 1833 & $\begin{array}{l}\text { Coal Bluff, Prices (=Halfway) } \\
\text { Bay (EN606358) }\end{array}$ & $\mathrm{T}_{\mathrm{r}}$ & & $\begin{array}{l}\text { O'Hara Booth letter } \\
15.10 .1833, \text { TSA }\end{array}$ \\
\hline 15 & Feb 1834 & $\begin{array}{l}\text { New Signal Hill } \\
\text { (Mt Communication) } \\
\text { (EN552322) }\end{array}$ & $\mathrm{Tr}$ & & Heard 1981: 169 \\
\hline $14 \mathrm{~A}$ & $\begin{array}{l}1837 \\
\text { (2nd rep.) }\end{array}$ & Deer Point & $\operatorname{Tr}$ & & Llotsky CSO $5 / 72 / 1584$ \\
\hline 16 & $<J u l 1838$ & Five Mile Beach & $\operatorname{Tr} ?$ & Anon. & $\begin{array}{l}\text { O'Hara Booth J. (Heard 1981: } \\
\text { 226) }\end{array}$ \\
\hline 17 & Dec 1838 & $\begin{array}{l}\text { Recherche Bay (northem } \\
\text { part) (DM928802) }\end{array}$ & $\mathrm{Tr}$ & $\begin{array}{l}\text { Capt. King } \\
\text { (mariner) }\end{array}$ & $\begin{array}{l}\text { Mackaness } 1947 ; n . b . \\
\text { Strzelecki } 1845: 137, \text { wrote of } \\
\text { two shafts at Recherche Bay }\end{array}$ \\
\hline 18 & $<1840$ & Southport (DM970908) & $\begin{array}{l}\text { UP } \\
1840\end{array}$ & Anon. & Exec. Counc. Min. 19 May \\
\hline $5 \mathrm{~A}$ & $\begin{array}{l}27.7 .1841 \\
\text { (redisc.) }\end{array}$ & Jerusalem (Colebrook) & $\operatorname{Tr}$ & James Clare & LSD I-28-458; 1 Aug 1841 \\
\hline 19 & $<\operatorname{Mar} 1843$ & $\begin{array}{l}\text { Apsley River (Llandaff) } \\
\text { (FP006584) }\end{array}$ & $\mathrm{Tr}$ & $\begin{array}{l}\text { Jesse \& Isaac Garland } \\
\text { (ticket-of-leave } \\
\text { convicts: "in the } \\
\text { mining business") }\end{array}$ & $\mathrm{CSO} 22 / 84 / 1807$ \\
\hline 20 & $<$ Mar 1843 & Denison Rivt (FP011687) & $\mathrm{Tr}$ & Jesse \& Isaac Garland & CSO $22 / 84 / 1807$ \\
\hline 21 & $\begin{array}{l}1843 \\
\text { (certainly } \\
<1849 \text { ) }\end{array}$ & Douglas River (FP002743) & $\operatorname{Tr}$ & Anon. & $\begin{array}{l}\text { J. Lyne, Apslawn in Proc. } R \text {. } \\
\text { Soc. V.D.L. 1: } 163\end{array}$ \\
\hline 22 & $\begin{array}{l}<1845 \\
\text { (prob. } \\
1840-42 \text { ) }\end{array}$ & Nine Mile Marsh & L & Anon. & Strzelecki 1845: 139 \\
\hline 23 & $\begin{array}{l}<1845 \\
\text { (prob. } \\
1840-42 \text { ) }\end{array}$ & $\begin{array}{l}\text { Spring Hill (London Inn) } \\
\text { EP212023 }\end{array}$ & $\mathrm{Tr}$ & Anon. & Strzelecki 1845: 128 \\
\hline 24 & $\begin{array}{l}<1845 \\
\text { (prob. } \\
1840-42 \text { ) }\end{array}$ & Ben Lomond (southem side) & $\mathrm{Tr}$ & Anon. & Strzelecki 1845: 126 \\
\hline 25 & $\begin{array}{l}<1845 \\
\text { (prob. } \\
1840-42 \text { ) }\end{array}$ & South Esk Valley & $\mathrm{L}$ & Anon. & Strzelecki 1845: 135 \\
\hline
\end{tabular}




\begin{tabular}{|c|c|c|c|c|c|}
\hline Item & Date & Locality & Age & Discoverer & Reference \\
\hline 26 & $<29.7 .1848$ & $\begin{array}{l}\text { Falmouth (possibly near } \\
\text { Germantown) (EQ988012) }\end{array}$ & $\mathrm{LP}$ & Anon. & Hobart Town Courier \\
\hline 27 & $<$ Nov 1848 & $\begin{array}{l}\text { "Lynwood", south of } \\
\text { Colebrook (EN338848) }\end{array}$ & $\mathrm{Tr}$ & Blinkworth & Milligan 1849: 73 \\
\hline 28 & Nov 1848 & Fingal (EP840895) & $\operatorname{Tr}$ & Anon. & Milligan 1849: 47 \\
\hline 29 & $<$ Nov 1848 & Mt Nicholas (EP925984) & $\operatorname{Tr}$ & Anon. & Milligan 1849: 50 \\
\hline 30 & $<$ Dec 1848 & Spring Bay EN758945 & $\operatorname{Tr}$ & Capt.(?) Vicary & Proc. R. Soc. VDL I: 159 \\
\hline 31 & $<1849$ & $\begin{array}{l}\text { Langloh ("High Plains") } \\
\text { DN843904 }\end{array}$ & $\mathrm{Tr}$ & Chilton & Proc. R. Soc. VDL I: 173 \\
\hline 32 & $<1849$ & $\begin{array}{l}\text { Back River, Buckland } \\
\text { EN64259045 }\end{array}$ & $\mathrm{Tr}$ & Anon. & Proc. R. Soc. VDL I: 175 \\
\hline $20 \mathrm{~A}$ & $\begin{array}{l}<1849 \\
\text { (?redisc.) }\end{array}$ & $\begin{array}{l}\text { Lagoon Rivt (=Denison } \\
\text { River) about } 5 \text { miles }(8 \mathrm{~km}) \\
\text { from Wabbs Hbr (=Bicheno) }\end{array}$ & $\mathrm{Tr}$ & Anon. & Proc. R. Soc. VDL I: 175 \\
\hline 33 & $<13.3 .1849$ & Ouse River DN76059635 & $\mathrm{L}$ & Anon. & Proc. R. Soc. VDL I: 272 \\
\hline 34 & $<8.5 .1850$ & Beckfords, Tamar River & $\mathrm{L}$ & Anon. & Proc. R. Soc. VDL I: 278 \\
\hline 35 & Jul 1850 & $\begin{array}{l}\text { Ben Lomond Rivt } \\
\text { EP482857 }\end{array}$ & $\operatorname{Tr}$ & J. Scott (Surveyor) & $\begin{array}{l}\text { Letter J. Scott to J. Milligan } \\
21.3 .1854 \text {. R. Soc. Tasm. } \\
\text { Archives, Secretary's } \\
\text { correspondence }\end{array}$ \\
\hline 36 & $<13.11 .1850$ & $\begin{array}{l}\text { Three Hut Point, Gordon } \\
\text { (EN194096) }\end{array}$ & UP & Anon. & Proc. R. Soc. VDL I: 298 \\
\hline $\begin{array}{l}37 \\
\text { DQ4 }\end{array}$ & $\begin{array}{l}<12.3 .1851 \\
431313\end{array}$ & Don River, Bott Gorge & LP & $\begin{array}{l}\text { Powell \& Ayres, } \\
\text { timber spliters }\end{array}$ & $\begin{array}{l}\text { Proc. R. Soc. VDL II(1): } \\
\text { 141-142; Fenton 1891: } 259\end{array}$ \\
\hline $\begin{array}{l}3 \mathrm{~A} \\
\text { (redis }\end{array}$ & $\begin{array}{l}<14.5 .1851 \\
\text { isc.) }\end{array}$ & $\begin{array}{l}\text { Blackwood Hills - well sunk } \\
\text { in flat on west bank of Tamar } \\
\text { River, } 2-3 \text { miles }(\sim 4 \mathrm{~km}) \\
\text { below Point Rapid (Rowella) } \\
\text { (DQ909438) }\end{array}$ & & Ralston & $\begin{array}{l}\text { Proc. R. Soc. VDL II }(1): \\
146\end{array}$ \\
\hline 38 & $\begin{array}{l}1851 \\
\text { (early) }\end{array}$ & Kelso (DQ820500) & $\mathrm{L}$ & ? J. Fereday (rector) & Proc. $R$. Soc. VDL II(1): 148 \\
\hline 39 & $<18.5 .1851$ & ?Port Sorell, in well at $28.6 \mathrm{~m}$ & $? \mathrm{~L}$ & & $\begin{array}{l}\text { Anon.Proc. } R \text {. Soc. VDL II(1): } \\
\text { 146; forwarded by Mr J.A. } \\
\text { Wheeler of Port Sorell }\end{array}$ \\
\hline 40 & $\begin{array}{l}<\text { Dec } 1851 \\
\text { (may be } \\
\text { redisc. of } 24 \\
\text { or } 35 \text { ) }\end{array}$ & $\begin{array}{l}\text { Ben Lomond }(3500 \mathrm{ft} \\
\sim 1100 \mathrm{~m}) \quad(\text { EP594930) }\end{array}$ & $\operatorname{Tr}$ & $\begin{array}{l}\text { ?J. Milligan (surgeon } \\
\text { and acting geologist) }\end{array}$ & Proc. R. Soc. VDL II(1): 166 \\
\hline $35 \mathrm{~A}$ & $\begin{array}{l}<13.8 .1851 \\
\text { (redisc.) }\end{array}$ & "Kingston" (near Avoca) & & ?Cotton & $\begin{array}{l}\text { Proc. R. Soc, VDL II (1): } \\
153\end{array}$ \\
\hline
\end{tabular}




\begin{tabular}{|c|c|c|c|c|c|}
\hline Item & Dite & Locality & Age & Discoverer & Reference \\
\hline 41 & $<\operatorname{Dec} 1851$ & St Pauls River (S side of) & $\operatorname{Tr}$ & $\begin{array}{l}\text { J. Milligan (surgeon } \\
\text { and acting geologist) }\end{array}$ & $\begin{array}{l}\text { Proc. R. Soc. VDL II(1); } \\
167\end{array}$ \\
\hline 42 & $<185$ & Whirlpool Reach (DQ924370) & $\mathrm{L}$ & Reid & $\begin{array}{l}\text { Proc. R. Soc. VDL II(1): } \\
104\end{array}$ \\
\hline 43 & 1852 (late) & $\begin{array}{l}\text { Coal Hill (near Mt Byron) } \\
\text { DP191492 }\end{array}$ & UP & $\begin{array}{l}\text { G.W. Burgess } \\
\text { (contract surveyor) }\end{array}$ & $\begin{array}{l}\text { Hobart Town Courier } 7 \text { June } \\
1853\end{array}$ \\
\hline 44 & $<$ May 1853 & $\begin{array}{l}\text { "Bryn Estyn" estate, New } \\
\text { Norfolk (near EN004640) }\end{array}$ & $? \mathrm{Tr}$ & Anon. & $\begin{array}{l}\text { Proc. R. Soc. VDL II(1): } \\
488\end{array}$ \\
\hline 45 & $<\operatorname{Mar} 1854$ & $\begin{array}{l}\text { Freshwater Point } \\
(\text { EQ064230) }\end{array}$ & $\mathrm{L}$ & ?P.S. Tomlins & $\begin{array}{l}\text { Proc. R. Soc. VDL III(1): } \\
161\end{array}$ \\
\hline $9 \mathrm{~A}$ & $\begin{array}{l}<\text { Aug } 1854 \\
\text { (?redisc.) }\end{array}$ & $\begin{array}{l}\text { Huon Rover (left bank near } \\
\text { Surveyors Beach; possibly } \\
\text { Sandrock Bay) }\end{array}$ & UP & ?J.L. Maclaine & $\begin{array}{l}\text { Proc. R. Soc. VDL III }(1) \text { : } \\
183\end{array}$ \\
\hline 46 & $<$ Nov 1854 & $\begin{array}{l}\text { Top of Constitution Hill, } \\
\text { Dysart EN186859 }\end{array}$ & $\operatorname{Tr}$ & ?T. Flude & $\begin{array}{l}\text { Proc. R. Soc. VDL III(1): } \\
192\end{array}$ \\
\hline 47 & $<1855$ & Russell DQ454342 & LP & Z. Williams (miner) & $\begin{array}{l}\text { Proc. R. Soc. VDL }(1855) \text { : } \\
\text { 136; Burns I964: } 226\end{array}$ \\
\hline 48 & 1855 & Denny Gorge DQ431338 & LP & Anon. & Gould 1861b; Burns 1964: 222 \\
\hline $\begin{array}{l}49 \\
\text { DQ4 }\end{array}$ & $\begin{array}{c}1855 \\
472334\end{array}$ & Denison, Tarleton & LP & $\begin{array}{l}\text { Anon. } \\
226\end{array}$ & Selwyn 1855; Burns 1964: \\
\hline 50 & 1855 & Plenty (DN980680) & $\mathrm{Tr}$ & $\begin{array}{l}\text { A.R.C. Selwyn } \\
\text { (geologist) }\end{array}$ & $\begin{array}{l}\text { Pap. Proc. R. Soc. Tasm. } \\
\text { 1855: } 116\end{array}$ \\
\hline $32 \mathrm{~A}$ & $\begin{array}{l}1855 \\
\text { (redisc.) }\end{array}$ & Back River, Prossers Plains & $\operatorname{Tr}$ & $\begin{array}{l}\text { A.R.C. Selwyn } \\
\text { (geologist) }\end{array}$ & $\begin{array}{l}\text { Pap. Proc. R. Soc. Tasm. } \\
\text { 1855: } 123\end{array}$ \\
\hline 51 & 1855 & Tarleton DQ472334 & LP & Z. Williams (miner) & Burns 1964: 226 \\
\hline 52 & $<1856$ & $\begin{array}{l}\text { "Sherwood", Clyde River } \\
\text { (doubtful record) }\end{array}$ & & ?Sherwin & Rep. R. Soc. VDL 1856: 34 \\
\hline 53 & $<1856$ & $\begin{array}{l}\text { Nook (Rays Prospect) } \\
\text { DQ436291 }\end{array}$ & LP & Anon. & $\begin{array}{l}\text { DoM Coal Production } \\
\text { Records }\end{array}$ \\
\hline 54 & $<1857$ & $\begin{array}{l}\text { Detention River (mouth of) } \\
\text { (CQ690740) }\end{array}$ & $\mathrm{L}$ & ?Emmett & $\begin{array}{l}\text { Rep. R. Soc. V.D.L. 1857: } \\
34\end{array}$ \\
\hline 55 & $<1857$ & Don DQ445347 & LP & Anon. & $\begin{array}{l}\text { Twelvetrees 1911: Burns } \\
\text { 1964: } 226\end{array}$ \\
\hline 56 & $<1858$ & Alfred DQ493333 & LP & Anon. & Burns 1964: 226 \\
\hline 57 & 1861 & Seymour (FP066764) & $\operatorname{Tr}$ & $\begin{array}{l}\text { Algernon H. Swift } \\
\text { (mining \& civil eng.) }\end{array}$ & $\begin{array}{l}\text { CSD 4/6/40, } 11 \text { Dec } 1861 \text {; } \\
\text { Horne, T. Report of Select } \\
\text { Committee on Coalfields. } \\
\text { House of Assembly Pap. } 95 \text {, } \\
\text { 1864: } 20\end{array}$ \\
\hline
\end{tabular}




\begin{tabular}{|c|c|c|c|c|c|}
\hline Item & Date & Locality & Age & Discoverer & Reference \\
\hline 58 & 1861 & Dalmayne (FP035845) & $\operatorname{Tr}$ & $\begin{array}{l}\text { Charles Gould } \\
\text { (geologist) }\end{array}$ & Gould 186Ia \\
\hline $41 \mathrm{~A}$ & $\begin{array}{l}1862 \\
\text { (?redisc.) }\end{array}$ & Lewis Hill (EP790675) & & Z. Williams (miner) & Select Committee 1864: 10 \\
\hline 59 & 1862 & $\begin{array}{l}\text { Swan River, Cranbrook } \\
\text { (EP892512) }\end{array}$ & $\mathrm{T}_{\mathbf{r}}$ & Z. Williams (miner) & Select Committee 1864: 20 \\
\hline 60 & 1862 & Tugrah DQ413378 & LP & Anon. & Bums 1964: 222, 241 \\
\hline 61 & 1862 & $\begin{array}{l}\text { Red Rock (Merrywood) } \\
\text { EP793748 }\end{array}$ & $\operatorname{Tr}$ & Z. Williams (miner) & Select Committee 1864: 20 \\
\hline 62 & 1863 & Mangana (EP710970) & LP & $\begin{array}{l}\text { T. Stephens (school } \\
\text { inspector \& amateur } \\
\text { geologist) }\end{array}$ & $\begin{array}{l}\text { Proc. } R \text {. Soc. VDL } \\
\text { Apr. } 1863\end{array}$ \\
\hline 63 & 1869 & Tin Dish Rivt, York Plains & $\operatorname{Tr}$ & $\begin{array}{l}\text { Charles Gould } \\
\text { (geologist) }\end{array}$ & Gould 1869 \\
\hline $36 \mathrm{~A}$ & $\begin{array}{l}<1864 \\
\text { (?redisc.) }\end{array}$ & Gordon (EN195100) & & Abbott & Select Committee 1864 \\
\hline 64 & 1875 & $\begin{array}{l}\text { Breadalbane (Big Cutting) } \\
\text { EQ185005 }\end{array}$ & L & ?R.M. Johnston & Johnston 1873: 42 \\
\hline 65 & 1874 & Tullochgorum (EP740870) & $\mathbf{L}$ & Grant & Johnston 1875: 58 \\
\hline 66 & 1876 & Cygnet EN125784 & UP & ?T. Nichols & $\begin{array}{l}\text { Proc. R. Soc. Tasm. (1876): } \\
70\end{array}$ \\
\hline 67 & $<1876$ & Kaoota (EN132368) & $\operatorname{Tr}$ & $\begin{array}{l}\text { J. Hurst (coal } \\
\text { merchant) }\end{array}$ & DoM lease files \\
\hline $9 \mathrm{~A}$ & (redisc.) & Randalls Bay EN100120 & UP & Anon. & Thureau 188Ia \\
\hline 68 & $<1880$ & Dulverton DQ488232 & $\mathbf{L P}$ & Anon. & DoM lease files \\
\hline 69 & $<1881$ & $\begin{array}{l}\text { Flynns Creek, Pelverata } \\
\text { (EN089376) }\end{array}$ & $\operatorname{Tr}$ & Anon. & Thureau $1881 \mathrm{~b}$ \\
\hline 70 & $<1886$ & Carr Villa (EQ140095) & $\mathbf{L}$ & Anon. & $\begin{array}{l}\text { Tasm. Sec. Mines Rep. } 1885 \\
\text { 1886: } 9\end{array}$ \\
\hline 71 & $<1886$ & $\begin{array}{l}\text { Compton, Old Beach } \\
\text { EN228633 }\end{array}$ & $\operatorname{Tr}$ & Brock & Johnston 1887: 155-156 \\
\hline 72 & $<1886$ & Belmont (EP085948) & $\mathbf{L}$ & Ritchie & $\begin{array}{l}\text { Tasm. Sec. Mines Rep. 1885- } \\
\text { 1886: } 10\end{array}$ \\
\hline 73 & $<1886$ & Longford (EQ096012) & $\operatorname{Tr}$ & Anon. & $\begin{array}{l}\text { DoM UG Plan 252; } \\
\text { Examiner } 29 \text { June } 1886\end{array}$ \\
\hline $58 \mathrm{~A}$ & $\begin{array}{l}1887 \\
\text { (redisc.) }\end{array}$ & Dalmayne & $\operatorname{Tr}$ & McMillan \& Inglis ${ }^{\dagger}$ & DoM lease files \\
\hline
\end{tabular}




\begin{tabular}{|c|c|c|c|c|c|}
\hline Item & Date & Locality & Age & Discoverer & Reference \\
\hline 74 & $<1888$ & Waratah (CQ765135) & $\mathrm{L}$ & Anon. & Nye 1923 \\
\hline 75 & $<1888$ & $\begin{array}{l}\text { Magnet Range (top of) } \\
\text { (CQ718128) }\end{array}$ & $\mathrm{L}$ & Anon. & Johnston 1888: 290 \\
\hline 76 & $<1888$ & $\begin{array}{l}\text { Long Bay (Strahan) } \\
\text { (CP618310) }\end{array}$ & $\mathrm{L}$ & Anon. & Johnston 1888: 294 \\
\hline 77 & $<1888$ & Rostella (EQ046245) & $\mathrm{L}$ & Anon. & Johnston 1888: 275 \\
\hline 78 & $<1888$ & $\begin{array}{l}\text { Macquarie Plains (junction of } \\
\text { Derwent \& Styx Rivers } \\
\text { (DN922710) }\end{array}$ & $\mathrm{L}$ & Anon. & Johnston 1888: 289 \\
\hline 79 & $<1888$ & Hastings DM909960 & $\operatorname{Tr}$ & Anon. & Johnston 1888: 191 \\
\hline $6 \mathrm{~A}$ & $\begin{array}{l}1888 \\
\text { (redisc.) }\end{array}$ & Coal Head (Macquarie Harbour) & & C.J. Peever ${ }^{\dagger}$ & DoM lease files \\
\hline 80 & 1888 & George Town DQ892491 & UP & M.J. Hackett* & Twelvetrees 1904 \\
\hline 81 & 1889 & Port Sorell DQ655423 & $\mathrm{L}$ & W. Barrett* & DoM lease files \\
\hline 82 & 1891 & Henty River (CP568480) & $\mathrm{L}$ & ?T.P.H. Jones & Johnston 1892 (1891): 12 \\
\hline 83 & 1891 & $\begin{array}{l}\text { Gould Point (Farm Cove) } \\
\text { (CP750085) }\end{array}$ & $\mathrm{L}$ & H.E. Bowcher" & DoM lease files \\
\hline 84 & 1891 & Henty River (CP590460) & LP & Anon. & Montgomery 1891: 42 \\
\hline $63 \mathrm{~A}$ & $\begin{array}{l}1892 \\
\text { (?redisc.) }\end{array}$ & Evandale Junction & $\mathrm{L}$ & Anon. & Montgomery 1892: 13 \\
\hline $40 \mathrm{~A}$ & $\begin{array}{l}1892 \\
\text { (prob. } \\
\text { redisc.) }\end{array}$ & $\begin{array}{l}\text { Storys Creek (at } 4000 \mathrm{ft} \text { - } \\
1200 \mathrm{~m} \text { ) }\end{array}$ & & Anon. & Montgomery $1892: 26$ \\
\hline 85 & 1892 & Mt Pelion East (DP217657) & UP & ?Joseph Will & Montgomery 1893: 2 \\
\hline 86 & 1892 & $\begin{array}{l}\text { Argenton ( } 5-6 \text { miles } S \text { of, } \\
\text { probably close to railway line } \\
\text { on or west of the Professor } \\
\text { Range) CP645495 }\end{array}$ & $\mathbf{L}$ & Anon. & $\begin{array}{l}\text { Tasm. Sec. Mines Rep. } \\
\text { 1896-97; Lease map Dep. } \\
\text { of Mines }\end{array}$ \\
\hline $50 \mathrm{~A}$ & $\begin{array}{l}1892 \\
\text { (?redisc.) }\end{array}$ & Plenty & & Anon. & Montgomery 1892: 13 \\
\hline 87 & 1892 & Ida Bay (DM920884) & $\operatorname{Tr}$ & Anon. & Twelvetrees $1902 c$ \\
\hline 88 & 1892 & Mt Ossa & UP & $\begin{array}{l}\text { Mole Creek \& Zeehan } \\
\text { Min. Prospecting } \\
\text { \& Exploration Co. }\end{array}$ & Montgomery 1893 \\
\hline 89 & 1892 & Mt Pclion West (DP170684) & UP & $\begin{array}{l}\text { Mole Creek \& Zeehan } \\
\text { Min. Prospecting } \\
\text { \& Exploration Co. }\end{array}$ & Montgomery 1893 \\
\hline
\end{tabular}




\begin{tabular}{|c|c|c|c|c|c|}
\hline Item & Date & Locality & Age & Discoverer & Reference \\
\hline 90 & 1892 & Barn Bluff (DP120790) & LP & J. Will (prospector) & Montgomery 1893: 2 \\
\hline 91 & 1894 & $\begin{array}{l}\text { Middleton Creek, Corinna } \\
\text { (CP403887) }\end{array}$ & $\mathrm{L}$ & Anon. & Thureau 1894 \\
\hline $43 \mathrm{~A}$ & 1897 & Mt Byron & UP & $\begin{array}{l}\text { T.H. Turner, S.L.A. } \\
\text { Moore }\end{array}$ & DoM lease files \\
\hline$? 89 \mathrm{~A}$ & 1898 & Mt Pelion West & UP & $\begin{array}{l}\text { W. Aylett \& P.H. } \\
\text { Parsons* }\end{array}$ & DoM lease files \\
\hline 92 & 1900 & Catamaran DM882782 & $\mathrm{Tr}$ & Major L. Hood & $\begin{array}{l}\text { Tasm. Sec. Mines Rep. } \\
\text { 1900: xiv }\end{array}$ \\
\hline 93 & 1900 & Moss Glen DM897803 & $\mathrm{T}_{\mathrm{r}}$ & G.H. Smith* & DoM lease files \\
\hline 94 & 1901 & Preolenna CQ760440 & LP & $\begin{array}{l}\text { W. Matthews, } \\
\text { J. Wilson, T. Harris, } \\
\text { D. Lowrie } \\
\text { (track cutters)* }\end{array}$ & Twelvetrees 1903 \\
\hline 95 & $<1901$ & $\begin{array}{l}\text { Eden (south of) } \\
\text { (CP588480) }\end{array}$ & UP & Woodcutters & Twelvetrees 1901 \\
\hline 96 & $<1902$ & $\begin{array}{l}\text { Mike Howes Marsh } \\
\text { (EP211216) }\end{array}$ & $\operatorname{Tr}$ & Anon. & Twelvetrees $1902 \mathrm{~b}$ \\
\hline 97 & 1902 & $\begin{array}{l}\text { Stanhope, Mt Christie } \\
\text { EP542817 }\end{array}$ & $\operatorname{Tr}$ & J. Stevenson* & Twelvetrees 1906 \\
\hline $83 \mathrm{~A}$ & $\begin{array}{l}1902 \\
\text { (?redisc.) }\end{array}$ & $\begin{array}{l}\text { Henty River (thin seams in } \\
\text { sandstone near the Henty } \\
\text { River) (CP590460) }\end{array}$ & LP & Anon. & Tasm. Sec. Mines Rep. 1902 \\
\hline 98 & 1908 & Strathblane (DM928989) & $\operatorname{Tr}$ & $\begin{array}{l}\text { Woods \& W. } \\
\text { Anderson }\end{array}$ & Twelvetrees 1915 \\
\hline 99 & 1909 & $\begin{array}{l}\text { Meander ("on branch of } \\
\text { Meander River, } 9 \text { miles west } \\
\text { from P.O.") (prob. S) }\end{array}$ & ?UP & E.A. Woodberry* & DoM lease files \\
\hline 100 & $<1911$ & Kimberley (DQ565159) & $\mathrm{L}$ & Anon. & Twelvetrees 1911: 32 \\
\hline 101 & $<1914$ & Berriedale (EN205605) & $\mathrm{Tr}$ & Anon. & Alexander 1986: 100 \\
\hline 102 & $<1914$ & Springfield EN228558 & $\operatorname{Tr}$ & Anon. & Alexander 1986: 100 \\
\hline 103 & $<1914$ & $\begin{array}{l}\text { Triffetts Pt (= Cadbury Point) } \\
\text { (EN228623) }\end{array}$ & $\operatorname{Tr}$ & Anon. & Alexander 1986: 100 \\
\hline 104 & 1915 & $\begin{array}{l}\text { Rocky Plains Bay } \\
\text { DM692765 }\end{array}$ & $\mathrm{L}$ & $\begin{array}{l}\text { W.H. Twelvetrees } \\
\text { (geologist) }\end{array}$ & Twelvetrees 1915: 16-18 \\
\hline 105 & 1916 & Mt Paul FP037422 & $\operatorname{Tr}$ & $\begin{array}{l}\text { C.J.Q. Lync* (farmer } \\
\text { and landowner) }\end{array}$ & DoM lease files \\
\hline
\end{tabular}




\begin{tabular}{|c|c|c|c|c|c|}
\hline Item & Date & Locality & Age & Discoverer & Reference \\
\hline 106 & 1917 & $\begin{array}{l}\text { Ben Lomond (Coal Mine } \\
\text { Crag) (EP535985) }\end{array}$ & $\operatorname{Tr}$ & $\begin{array}{l}\text { J.B. Dean \&F.R. } \\
\text { Davis* }\end{array}$ & $\begin{array}{l}\text { DoM lease files; also } \\
\text { Hills et al. } 1922: 214\end{array}$ \\
\hline 107 & $<1919$ & $\begin{array}{l}\text { Great Fitzroy (near } \\
\text { Meunna) } \\
\text { (CQ765478) }\end{array}$ & LP & Anon. & Tasm. Sec. Mines Rep. 1919 \\
\hline 108 & 1919 & $\begin{array}{l}\text { ?Myrtle Hill (= Johns Hill) } \\
\text { Irishtown (CQ458682) }\end{array}$ & $\mathrm{L}$ & McGillivray* & $\begin{array}{l}\text { Nye et al. 1934: } 55 \\
\text { DoM Reward leases }\end{array}$ \\
\hline 109 & 1919 & $\begin{array}{l}\text { Hagley (Rosevale) } \\
\text { (DQ966115) }\end{array}$ & $\mathrm{L}$ & L. Gatenby & $\begin{array}{l}\text { Tasm. Sec. Mines Rep. 1919: } \\
32\end{array}$ \\
\hline 110 & $<1922$ & $\begin{array}{l}\text { Dawsons Siding (mouth of } \\
\text { Caroline Creek) DQ498304 }\end{array}$ & LP & Anon. & $\begin{array}{l}\text { Hills et al. 1922: pl.xxxiv; } \\
\text { Dix in Jennings 1979: } 107\end{array}$ \\
\hline 111 & $<1922$ & Old Mans Rivt EP834228 & $\mathrm{Tr}$ & Anon. & Hills et al. 1922: 104 \\
\hline 112 & 1922 & Lune River & $\operatorname{Tr}$ & Anon. & Hills et al. 1922: 169 \\
\hline 113 & $<1922$ & $\begin{array}{l}\text { Brambletye (W side of } \\
\text { Bonneys Plains) (EP504741) }\end{array}$ & $\operatorname{Tr}$ & Anon. & Hills et al. 1922: 30,212 \\
\hline 114 & 1922 & Buckland EN574935 & $\operatorname{Tr}$ & A.E. French* & DoM lease files \\
\hline 115 & $<1924$ & Northdown DQ592447 & $\mathrm{L}$ & Anon. & Nye 1928 \\
\hline 116 & $<1924$ & $\begin{array}{l}\text { Harford — Iles \& Parsons } \\
\text { DQ594363 }\end{array}$ & $\mathrm{L}$ & Anon. & Reid 1924: 29, 102-103 \\
\hline 117 & $<1924$ & Harford (Burgess) DQ608344 & $\mathrm{L}$ & Anon. & Reid 1924: 29, 104-105 \\
\hline 118 & $<1924$ & $\begin{array}{l}\text { Sassafras } \\
\text { Driscolls } \quad \text { DQ554319 } \\
\text { Ingrams }\end{array}$ & $\mathrm{L}$ & Anon. & Reid 1924: 30 \\
\hline 119 & $<1924$ & Dunorlan (DQ603069) & $\mathrm{L}$ & Anon. & Reid 1924: 94 \\
\hline 120 & 1929 & $\begin{array}{l}\text { Rose Rivt (EQ216013) } \\
\text { (from 201021-231016) }\end{array}$ & $\mathrm{L}$ & Anon. & Nye 1929 \\
\hline 121 & 1930 & $\begin{array}{l}\text { Sea Elephant River (King } \\
\text { 1sland) (BR500900) }\end{array}$ & $\mathrm{L}$ & R. Hooper & Carey 1946 \\
\hline 122 & 1930 & Mt Elephant (FP035905) & $\operatorname{Tr}$ & A.E. Cooper* & DoM lease files \\
\hline 123 & 1934 & $\begin{array}{l}\text { Edith Creek (near Lileah) } \\
\text { (CQ460614) }\end{array}$ & $\mathrm{L}$ & Anon. & Nye et al. 1934: 55 \\
\hline 124 & 1938 & $\begin{array}{l}\text { Rooks River (Cape Barren } \\
\text { Island) (ER975325) }\end{array}$ & $\mathrm{L}$ & Anon. & Blake 1938: 3 \\
\hline 125 & $<1952$ & Mt Lloyd (DN930509) & $\operatorname{Tr}$ & L. Teakle & Hughes 1952 \\
\hline 126 & 1955 & Adamsons Peak (DN872205) & UP & Anon. & Hughes 1955 \\
\hline 127 & 1960 & $\begin{array}{l}\text { Wesley Vale }(1.2 \mathrm{~km} \mathrm{~N} \text { of) } \\
\text { (DQ540410) }\end{array}$ & L & Anon. & $\begin{array}{l}\text { Hughes \& Burns } \\
\text { 1961(60): } 198\end{array}$ \\
\hline
\end{tabular}




\begin{tabular}{|c|c|c|c|c|c|}
\hline Item & Date & Locality & Age & Discoverer & Reference \\
\hline 128 & 1960 & $\begin{array}{l}\text { Hastings Caves Road } \\
\text { (DM895938) }\end{array}$ & $\mathrm{L}$ & Anon. & Hughes 1960: 32 \\
\hline 129 & 1960 & $\begin{array}{l}\text { Relapse Creek (West } \\
\text { Takone) (CQ726412) }\end{array}$ & LP & B. Farquhar & $\begin{array}{l}\text { McNeil 1961; Hughes } \\
\text { 1962(61): } 55\end{array}$ \\
\hline 130 & 1979 & $\begin{array}{l}\text { Tower Hill (East Tower) } \\
\text { (EQ716002) }\end{array}$ & & & Comwall Coal Co. drilling \\
\hline 131 & 1981 & Woodbury (EP370330) & $\operatorname{Tr}$ & $\begin{array}{l}\text { Victor Petroleum } \\
\text { (on advice from } \\
\text { S. Forsyth, geologist) }\end{array}$ & \\
\hline 132 & 1983 & Kempton EN130964 & $\operatorname{Tr}$ & $\begin{array}{l}\text { C.A. Bacon } \\
\text { (geologist) }\end{array}$ & DoM unpubl. rep. $1983 / 33$ \\
\hline 133 & 1986 & $\begin{array}{l}\text { Rabbit Marsh, headwaters of } \\
\text { Nile River EP489965 }\end{array}$ & $\operatorname{Tr}$ & $\begin{array}{l}\text { J.L. Everard } \\
\text { (geologist) }\end{array}$ & J. Everard (pers. comm.) \\
\hline 134 & 1988 & Bushy Park (DN918720) & $\mathrm{L}$ & $\begin{array}{l}\text { P. Plummer } \\
\text { (fireman) }\end{array}$ & C. Bacon (pers. comm.) \\
\hline
\end{tabular}




\section{APPENDIX 2}

\section{Years of Operation of Tasmanian Coal Mines}

Dates of opening and operation of coal mines in Tasmania; based predominantly on retums of production to Department of Mines, partly on historical sources. Mines have been listed in chronological order within a decade of first operation. The letters in brackets after the name of a mine indicate the field or general area in which the mine lies. The letters have the following meanings: A - Avoca; $\mathrm{Ck}$-Colebrook; Cn-Catamaran; $\mathrm{Ct}-\mathrm{Cygnet}$ area, widely interpreted; DV - Derwent Valley; EC - East Coast; F-Fingal, Mt Nicholas, St Marys; M - Mersey district; Md - Midlands; N - northem Tasmania; NW - northwestem Tasman ia; S - south, Hastings area; SPR - - St Pauls River; TP - Tasman Peninsula.

$1800-1809$

Richmond, possibly 1804-1805; 1841-42

$1830-39$

Saltwater River (TP), 1834-77

Mt Communication (TP), 1836

\section{$1840-49$}

Jerusalem (Ck), 184l-44, 1879-90, 1894, 1910-11 Southport (S), 1842

Schouten Island (EC), 1843-44, 1848-50, 1888-92

Denison Rivulet (EC), 1849-58

Recherche $(\mathrm{Cn}), 1840$ 's (year unknown)

\section{$1850-59$}

Bott Gorge (M), 1851--57

New Town (DV), 1851-?53, 1872-76, 1883, 1910-11

Denny (M), 1853-54

Tarleton (M), 1853-55

Alfred (M), 1855-83

Denison (M), 1855-59

Don (M), 1855-83

Nook (M), 1855, 1931, 1938-42

Triabunna (EC), 1855

\section{$1860-69$}

Sherwood (M), 1861

Mersey (M), 1861-90

Seymour (EC), 1863-80, 1923-31, 1959-64

Gordon (Rookwood) (Ct), 1864-79

Merrywood (SPR), 1864, 1945, 1948--52, 1953-63, 1985-86

Tugrah (M), 1865-83

Russell (M), 1867-99

$1870-79$

Back River (EC), 1874, 1921

Adventure Bay (Ct), 1878-81 ... to $1890^{\prime}$ 's

1880-89

Flynns Creek (Ct), pre-1881

Randalls Bay (Ct), pre -1881

Douglas River (EC), 1881-82, 1886, 1901-1902,

1905-1908, 1914-25

Kaoota (Ct), 1881-1910, 1917-19, 1937-71

Mount Cygnet (Ct), 1881-1923

Rileys Mines (M), 1881-1900

York Plains (Md), 1883-1902, 1905-47

Cornwall (F), 1886-1964
Norwich (N), 1886-1919

Dalmayne (F), 1887-92, 1915-19, 1939-53

Hastings (S), pre-1888

Mt Nicholas (F), 1888-1956

George Town (N), 1889

$1890-99$

Bayntons Tasma, Colebrook (C), 1892-97, 1911

Ben Lomond (Storeys Creek) (A), 1892

Ida Bay $(\mathrm{S}), 1892,1909-11$

Jubilee $(\mathrm{F}), 1897-1902,1920-60$

1900-1909

Hood Workings (Cn), 1900-1910

Cardiff (F), 1901-14, 1917, 1966

Moss Glen (Cn), 1902-12

Spreyton No.1 (M), 1902-1903

Glen Leith (Ck), 1903

Illamatha No.1 (M), 1903-42

Marialva (Ck), 1903-1904

Preolenna (NW), 1903-13, 1918-24

Spreyton No.2 (M), 1903-1904

Spreyton No.3 (M), 19041908

Brightbum (M), 1905

Buena Vista (A), 1905

Spreyton No.4/Mersey/Allisons (M), 1909-16

Heaney (Ct), 1900's

1910-19

James Workings (Cn), 1910-12

Lewis Hill (SPR), 1910-20

Strathblane (S), 1910-15

Aberdeen (M), 1913-50

New Main Shaft (Cn), 1913-14

Pateena (N), 1916-19

Mt Paul (EC), 1916

Spreyton No.5 (M), 1917-23

Great Fitzroy (NW), 1919

$1920-29$

Fingal (F), 1920-65

Silkstone (F), 1920, 1950-51

Buckland (Sand River) (EC), 1921

Impression Bay (TP), pre-1922

Sloanes (M), pre-1922

Lune River (S), 1922

Dawsons Siding (M), 1923-25

Mackenzie Workings (Cn), 1923-30

Stanhope (Excelsior) (A), 1923-57 
Meunna/Torban Hill (NW), 1925-28, 1935-36 Anthracite Workings (Cn), 1927

\section{0-39}

Coventry No.1 (M), 1931-39

Dulverton (M), 1931-39

Esk Bank (M), 1931-38

Hard-to-get (M), 1931-37

Last Chance (M), 1931-33

Lucky Hit (M), 1931-38

Lucky Nook (M), 1931

Ribbon Workings (Cn), 1931

Southern Star (M), 1931-36

Star (M), 1931-32, 1934-37

Black Beauty (M), 1933-44

Dulverton Tribute (M), 1933-34

Stronach Tunnel (Cn), 1934

Brickyard (M), 1935-36

McCreghan \& Sons (M), 1937-38

Botts No.2 (M), 1938

G. Jeffrey (M), 1938

Langloh (DV), 1938-63

Novelty (M), 1938-39

Sheehans (M), 1938

Shepheard \& party (M), 1938

J. Bott (M), 1939
Bott \& Jeffrey Bros (M), 1939

Botts (M), 1939-42

Coventry No.2 (M), 1939-46

Gordon Workings (Ct), 1939-40

$1940-49$

Mr Christie No.1 (A), 1940-57

Illamatha No.2 (M), 1943-61

Duncan (F), 1946-present

1950-59

Tasmania (F), 1954-57, 1962-63

Barbers (F), 1955-64

Mt Christie No.2 (A), 1958-63

New Stanhope (A), 1958-71

1960-69

None

1970-79

None

1980-

Blackwood (F), 1981-present Fenhope (A), 1981-present 


\section{APPENDIX 3}

Reasons Given for Closure of Coal Mines in Tasmania

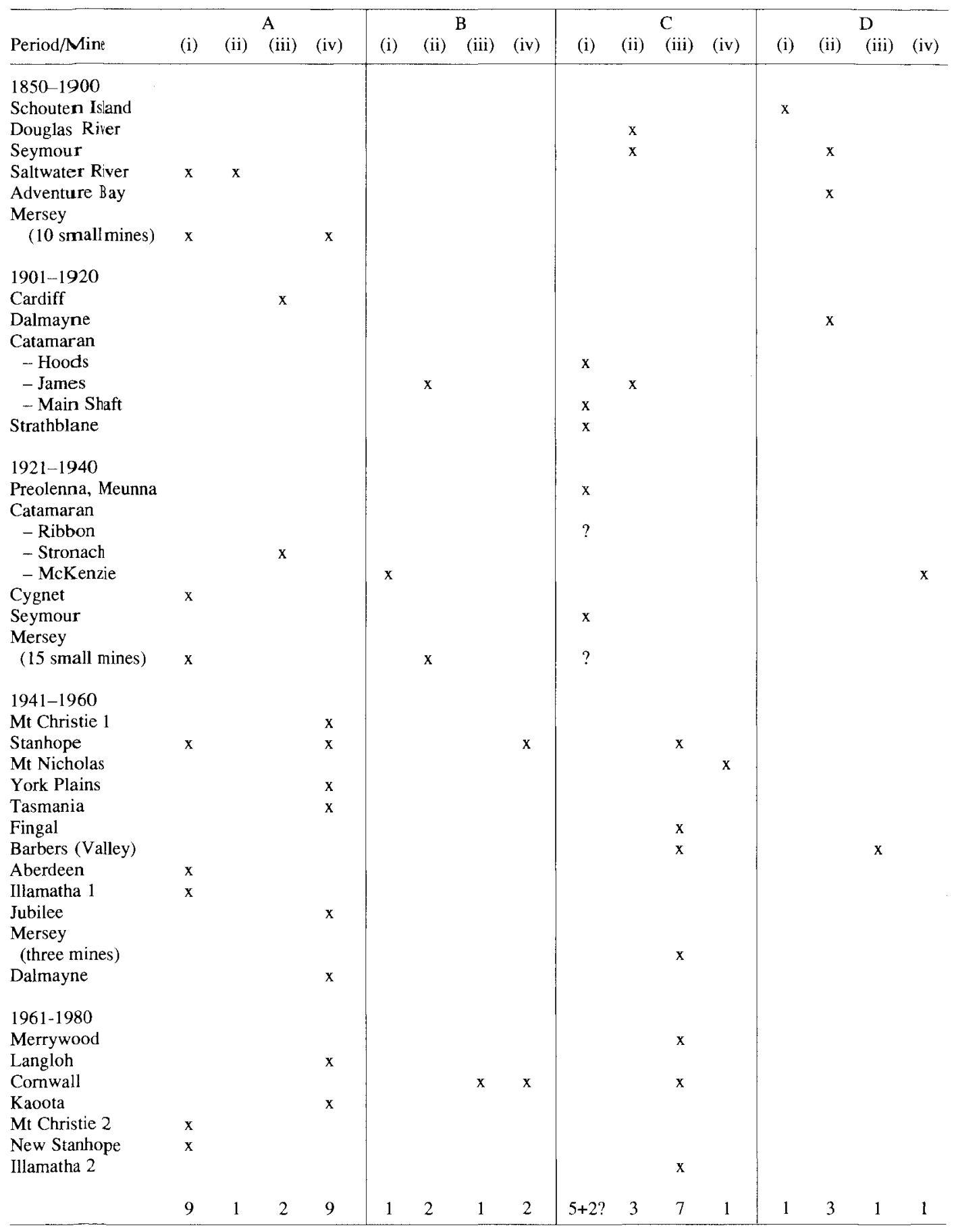




\section{A. Geological causes \\ (i) mined out or nearly so \\ (ii) poor quality coal \\ (iii) reached a fault \\ (iv) badly faulted or deteriorating geological conditions}

$\begin{array}{ll}\text { B. } & \text { Mine failures } \\ \text { (i) } & \text { flooding } \\ \text { (ii) } & \text { collapse(s) } \\ \text { (iii) } & \text { floor heave } \\ \text { (iv) } & \text { fire }\end{array}$

\section{Classification of Reasons}

\author{
C. Economic causes \\ (i) lack of capital \\ (ii) overcapitalisation on infrastructure \\ (iii) loss of markets \\ (iv) taken over and closed \\ D. Fortuitous causes \\ (i) lease not renewed; Government planned \\ a probation station in the same area. \\ (ii) jetty washed away \\ (iii) pony died before replacement was trained \\ (iv) demarcation dispute on the Hobart wharves.
}

